\title{
Educação Especial e
}

Educação Inclusiva:

\section{DIREITO DE TODOS}

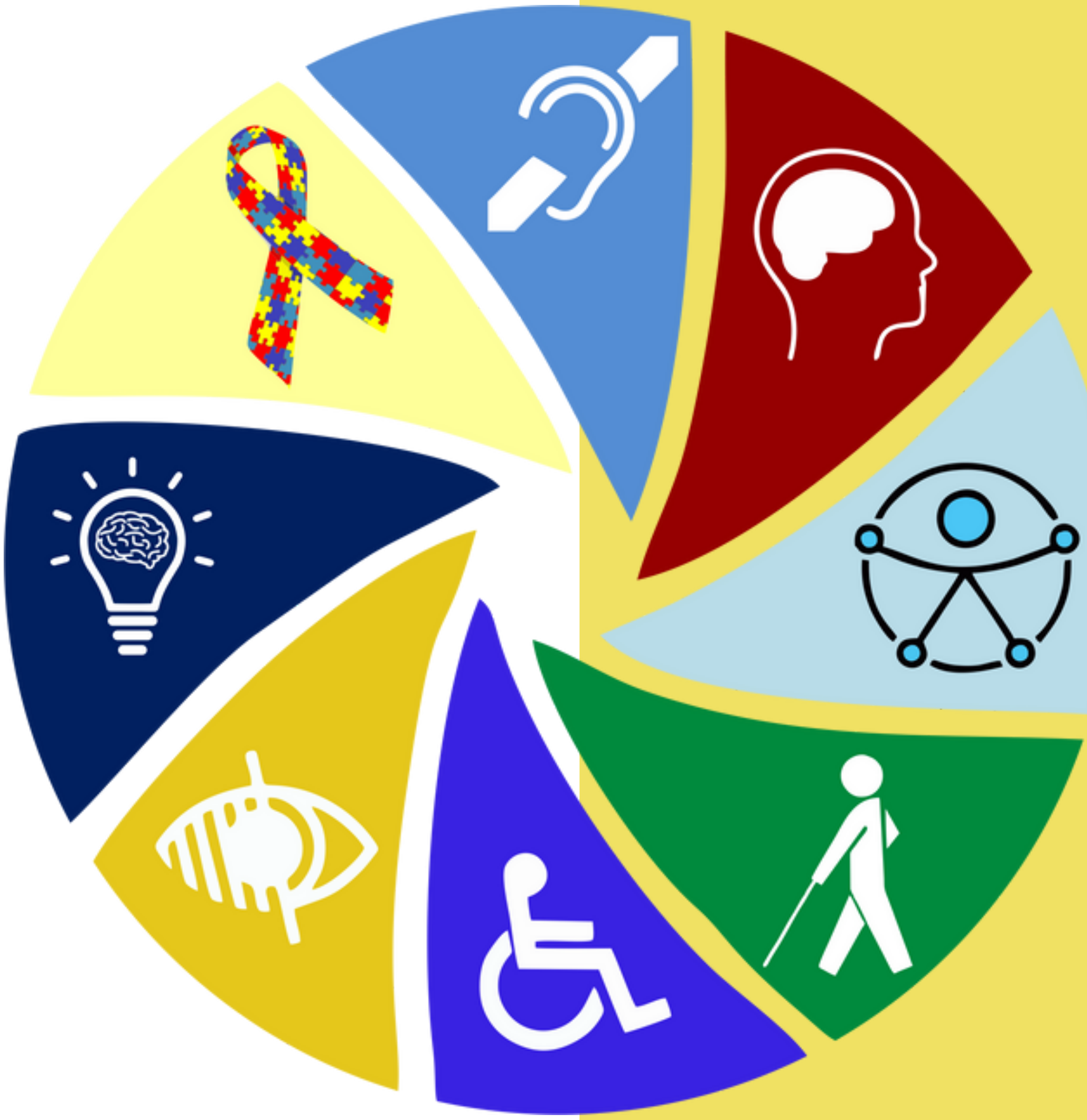


Educação Especial e Educação Inclusiva:

\section{DIREITO DE TODOS}

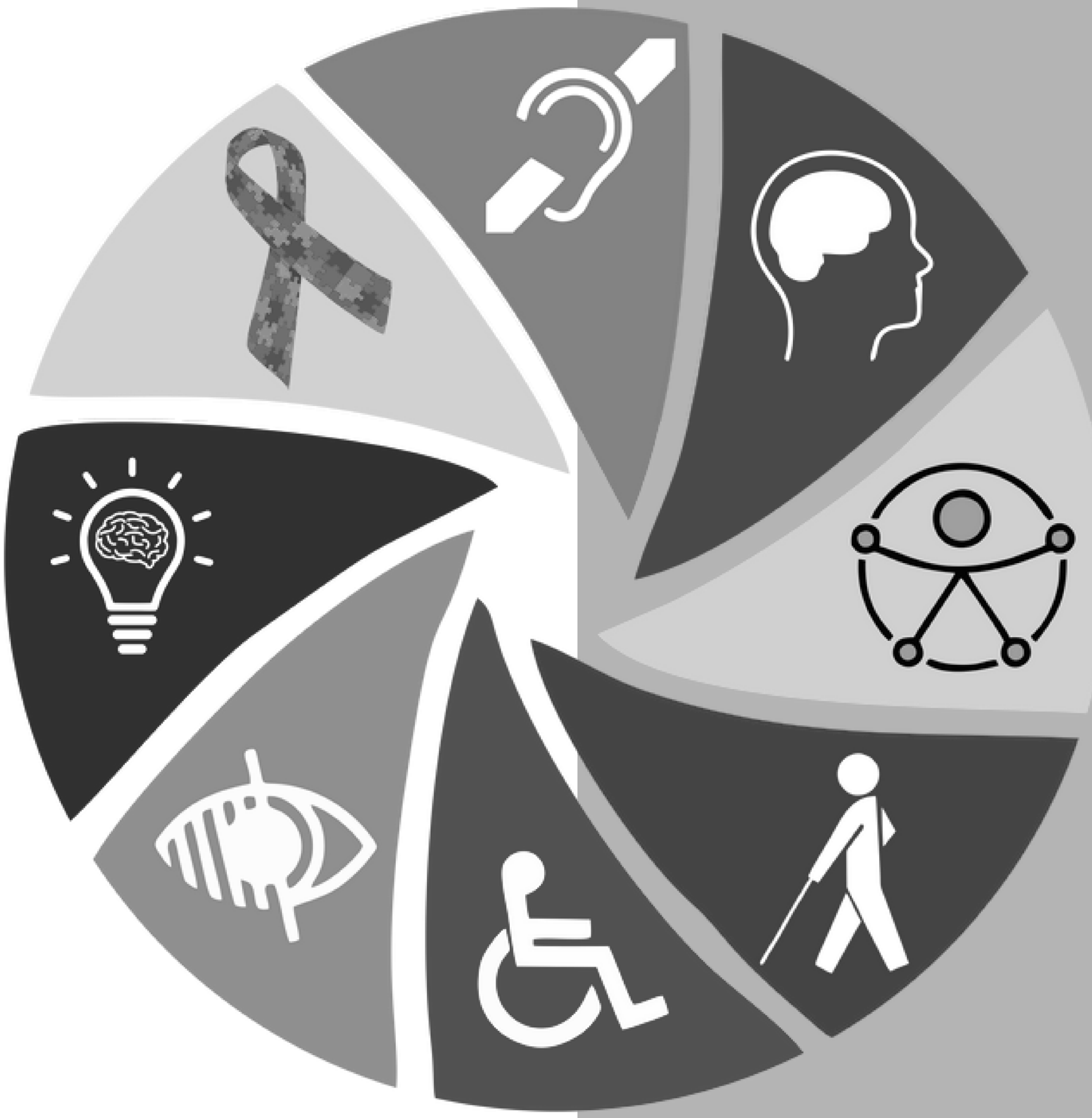


O conteúdo dos capítulos apresentados nesta obra são de inteira responsabilidade $\mathrm{d} @$ s autor@s, não representando necessariamente a opinião da Editora.

Permitimos a reprodução parcial ou total desta obra, considerado que seja citada a fonte e a autoria, além de respeitar a Licença Creative Commons indicada.

\section{Conselho Editorial}

Adilson Cristiano Habowski

Anísio Batista Pereira

Adilson Tadeu Basquerote Silva

Alexandre Carvalho de Andrade

Cristiano Cunha Costa

Emily Verônica Rosa da Silva Feijó

Fernanda Monteiro Barreto Camargo

Fredi dos Santos Bento

Fabiano Custódio de Oliveira

Guilherme Mendes Tomaz dos Santos

Leandro Antônio dos Santos

Lourenço Resende da Costa

\section{Diagramação:}

Gabriel Eldereti Machado

Revisão:

dos/as autores/as.

\section{Capa:}

Gabriel Eldereti Machado

imagem capa:

www.educ.see.ac.gov.br 


\section{Dados de Catalogação na Publicação (CIP)}

Dados de Catalogação na Publicação (CIP)

Educação Especial e Educação Inclusiva: Direito de todos [livro eletrônico] / organização

Priscilla Basmage Lemos Drulis. -- Alegrete, RS

: TerriED Editora, 2021.

PDF

ISBN $978-65-995948-2-3$

1. Educação.

I. DRULIS, Priscilla Basmage Lemos.

CDD-370

CDU-21-37/49

Índices para catálogo sistemático:

1. Educação 370.

\section{TERRIED}

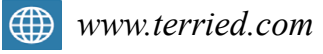

\contato@terried.com

(O) leditora_terried/ 


\section{APRESENTAÇÃo}

O capítulo 1 intitulado "O TRABALHO EM COLABORAÇÃO NA EDUCAÇÃO ESPECIAL E OS DESAFIOS DO ENSINO REMOTO”, da autora Dorismar Recaldes, traz uma discussão sobre os desafios encontrados no ensino comum pelos professores especialistas e professores regentes que trabalham escolarização de alunos com deficiência neste contexto de pandemia, para tanto reporta-se a pesquisadores da área de Educação Especial e suas produções acerca do trabalho realizado por professores especialistas na área e professores do Ensino Comum.

O capítulo 2 intitulado "IDENTIDADE E REPRESENTAÇÃO: UM OLHAR SOBRE A EXCLUSÃO E O PRECONCEITO EM RELAÇÃO AO /A ALUNO/A INDÍGENA NA EDUCAÇÃO SUPERIOR”, da autora Irení Aparecida Moreira Brito, busca-se demonstrar, por meio de uma análise discursiva, sobre a exclusão e o preconceito em relação ao/a acadêmico/a indígena, ingressantes por meio do regime de cotas na Universidade Estadual de Mato Grosso do Sul - UEMS, destacando-se aspectos como identidade e representação, a partir da realização de entrevistas semiestruturadas, momento em que os/ as pesquisadores/as perceberam alguns fenômenos discursivos que demonstravam marcas que reveladoras de preconceito e exclusão em relação às entrevistadas, marcas estas que influenciaram o olhar dessas egressas sobre a Universidade e sobre os sujeitos que nela atuam.

No capítulo 3 chamado "NÚCLEO DE ATIVIDADES DE ALTAS HABILIDADES/SUPERDOTAÇÃO (NAAH/S) DE MATO GROSSO DO SUL: IDENTIFICAÇÃO, PLANEJAMENTO E ATENDIMENTO”, das autoras Graziela Cristina Jara e Nadia Bigarella, discute o processo de identificação da Altas Habilidades/Superdotação no contexto escolar, desenvolvido pela equipe do Núcleo de Atividades de Altas Habilidades/ Superdotação, como uma política de ação da Secretaria de Estado de Educação de Mato Grosso do Sul/MS, para construir uma educação inclusiva.

O capítulo 4 nomeado "ATENDIMENTO EDUCACIONAL ESPECIALIZADO PARA ESTUDANTES COM CARACTERÍSTICAS DE PRECOCIDADE”, da autora 
Priscilla Basmage Lemos Drulis, decorre de um relato de experiência sobre o atendimento educacional especializado para precoces com indicativos de Altas habilidades/Superdotação, ofertado pelo Centro Estadual de Atendimento Multidisciplinar para Altas Habilidades/Superdotação (CEAM/AHS), situado em Campo Grande - MS, que tem como desígnio identificar e promover o atendimento, bem como efetivar a avaliação formal para Altas Habilidades/Superdotação.

No capítulo 5, chamado "HISTÓRIA E LEGISLAÇÃO: A EDUCAÇÃO DE SURDOS", da autora Joice Vareiro da Costa Brites, objetiva traçar os pontos históricos e principais sobre a língua de sinais, para conhecimento e progresso dessa linguagem ao longo da história. O capítulo tem o intuito não só de informar, mas também de alertar sobre as leis que amparam a educação da criança surda, que por gerações foi negligenciada, e atualmente podemos identificá-las.

O capítulo 6 com o título "IDENTIFICANDO ESTUDANTES COM ALTAS HABILIDADES/SUPERDOTAÇÃO NO ENSINO FUNDAMENTAL I", das autoras Priscilla Basmage Lemos e Marcela Luzio Ferreira Moquiuti, realiza uma investigação e levanta dados quantitativos e qualitativos com os estudantes dos $5^{\circ}$ anos do Ensino Fundamental I das Escolas Estaduais de Campo Grande/MS, com o intuito de identificá-los e selecioná-los para avaliação de $\mathrm{AH} / \mathrm{SD}$, garantindo o direito ao Atendimento Educacional Especializado (AEE).

E por fim, no capítulo 7, intitulado "DESAFIOS E AVANÇOS DAS ESCOLAS E PROFESSORES FRENTE A EDUCAÇÃO ESPECIAL”, da autora Juliana Campos Francelino, foi realizado um estudo teórico e de análise documental, com destaque na análise de conteúdo de leis, decretos, resoluções, objetivando apontar os desafios e avanços das escolas e dos profissionais da educação frente as demandas dos alunos com algum tipo de deficiência., demonstrando a necessidade de uma escola acolhedora que veja a todos com igualdade, e que garanta o acesso de todos os alunos ao conhecimento, a socialização e à convivência, promovendo a inclusão. 


\section{SUMÁRIO}

CAPÍTULO 1

O TRABALHO EM COLABORAÇÃO NA EDUCAÇÃO ESPECIAL E OS DESAFIOS DO ENSINO REMOTO.

Dorismar Recaldes

doi: 10.48209/978-65-995948-0-3

CAPÍTULO 2

IDENTIDADE E REPRESENTAÇÃO: UM OLHAR SOBRE A EXCLUSÃO E O PRECONCEITO EM RELAÇÃO AO /A ALUNO/A INDÍGENA NA EDUCAÇÃO SUPERIOR................................................................................18

Irení Aparecida Moreira Brito

doi: 10.48209/978-65-995948-1-3

CAPÍTULO 3

NÚCLEO DE ATIVIDADES DE ALTAS HABILIDADES/SUPERDOTAÇÃO (NAAH/S) DE MATO GROSSO DO SUL: IDENTIFICAÇÃO, PLANEJAMENTO E ATENDIMENTO

Graziela Cristina Jara

Nádia Biagrella

doi: 10.48209/978-65-995948-2-E

CAPÍTULO 4

ATENDIMENTO EDUCACIONAL ESPECIALIZADO PARA ESTUDANTES COM CARACTERÍSTICAS DE PRECOCIDADE..................................51

Priscilla Basmage Lemos Drulis

doi: 10.48209/978-65-995948-3-3 
CAPÍTULO 5

HISTÓRIA E LEGISLAÇÃO: A EDUCAÇÃO DE SURDOS

62

Joice Vareiro da Costa Brites

doi: 10.48209/978-65-995948-4-3

CAPÍTULO 6

IDENTIFICANDO ESTUDANTES COM ALTAS HABILIDADES/SUPERDOTAÇÃO NO ENSINO FUNDAMENTAL I

73

Priscilla Basmage Lemos Drulis

Marcela Luzio Ferreira Moquiuti

doi: 10.48209/978-65-995948-5-3

CAPÍTULO 7

DESAFIOS E AVANÇOS DAS ESCOLAS E PROFESSORES FRENTE A EDUCAÇÃO ESPECIAL 83

Juliana Campos Francelino

doi: 10.48209/978-65-995948-6-3

CAPÍTULO 8

ALTAS HABILIDADES/SUPERDOTAÇÃO: UM OLHAR PARA IDENTIFICAÇÃ O.....................................................................94

Marcela Luzio Ferreira Moquiuti

doi: 10.48209/978-65-995948-7-3

SOBRE A ORGANIZADORA. 


\title{
CAPÍTULO 1
}

\section{OTRABALHOEM}

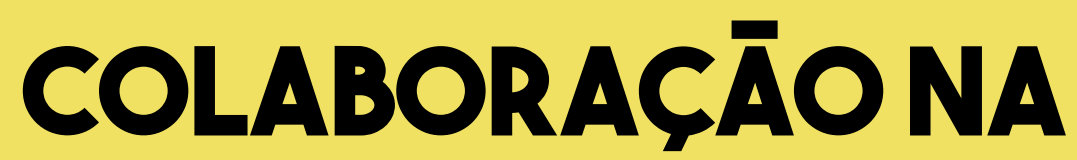

\section{EDUCAÇĀOESPECIALE OS}

\section{DESAFIOS DOENSINO REMOTO}

\author{
Dorismar Recaldes ${ }^{1}$
}

1 Mestre em Educação pela Universidade Estadual de Mato Grosso do Sul (UEMS). Especialista em Psicopedagogia pela Universidade Católica Dom Bosco (UCDB). Especialista em Diversidade e Educação Especial para a Inclusão Educacional, pelo Centro Universitário Leonardo da Vinci/SC. É membro do Grupo de Pesquisas em Inclusão e Educação Especial - GEPIEE/UFMS e membro do Grupo de Pesquisa em Educação Especial - GPEE/UEMS. E-mail: dorinhamoroskoski@gmail.com. Orcid: https://orcid.org/0000-0001-6595-5017 
Resumo: A discussão sobre a inclusão escolar em nossa sociedade ainda é um desafio, mesmo que a prática de ensino na perspectiva da Educação Inclusiva seja garantida nas legislações vigentes que tratam da Educação Especial. Atualmente, e principalmente em tempos de pandemia, observamos grandes questionamentos sobre de quem seria a responsabilidade das intervenções que viabilizem a escolarização dos alunos público alvo da educação especial no contexto escolar, quando este, tem professor especialista que o auxilia em sala de aula. Os estudos com relação ao trabalho que envolve a parceria e colaboração entre professor especialista e professor do ensino comum são recentes, porém, o tema é abordado por vários autores e outros citados neste texto. O presente artigo tem como objetivo levantar quais são os desafios encontrados no ensino comum pelos professores especialistas e professores regentes que trabalham escolarização de alunos com deficiência neste contexto de pandemia. De quem seria a responsabilidade por essa escolarização? Para tanto iremos nos reportar a pesquisadores da área de Educação Especial e suas produções acerca do trabalho realizado por professores especialistas na área e professores do Ensino Comum.

Palavras chave: Educação especial, práticas inclusivas, pandemia da covid-19.

\section{INTRODUÇÃo}

Historicamente, vimos as pesquisas voltadas para o desenvolvimento escolar de pessoas com deficiência saírem de modelo clinico, que não favorecia a aprendizagem de estudantes com deficiência, na medida em que só se objetivavam e priorizavam, em muitos casos, atendimentos estritamente especializados por acharem ser esse o caminho que facilitaria o desenvolvimento destes estudantes.

Dentro deste contexto, nos últimos anos, a prática escolar na perspectiva da Educação Inclusiva vem sendo traçada por meio de estudos e leis que transpassam este processo de inclusão do estudante com deficiência no ensino comum.

Para tanto, a resolução CNE/CEB nº 02/2001, nos traz o conceito de educação especial onde diz que se trata de:

(...) uma proposta pedagógica, assegurando um conjunto de recursos e serviços para apoiar, suplementar, e, em alguns casos, substituir os serviços educacionais comuns de modo a garantir a educação escolar e promover o desenvolvimento das potencialidades dos educandos que apresentam necessidades educacionais especiais, em todos os níveis, etapas e modalidades da educação (BRASIL, 2001, p.106) 
Dessa forma, a Educação Especial propõe que os professores envolvidos na escolarização das pessoas com deficiência, altas habilidades e superdotação atendam os mesmos em suas necessidades educativas em sala de aula no ensino regular, viabilizando a aprendizagem e o desenvolvimento de todos os estudantes.

Segundo Pacheco (2007, p.15):

As práticas pedagógicas numa escola inclusiva precisam refletir uma abordagem mais diversificada, flexível e colaborativa do que numa escola tradicional. A inclusão pressupõe que a escola se ajuste a todas as crianças que desejam matricular-se em sua localidade, em vez de esperar que determinada criança com necessidades especiais se ajuste à escola (integração).

A proposta do autor, em suas colocações sobre a construção desse processo de inclusão, durante este tempo de pandemia, nos remete a reflexão ainda maior sobre as necessidades especificas do estudante com deficiência e, obrigatoriamente, a uma mudança de estratégias e ações que favoreçam a aprendizagem do estudante público alvo da educação especial com aulas remotas.

A pandemia nos incumbiu a um desafio ainda maior do que já estávamos vivenciando no contexto do ensino comum quando tratávamos da escolarização de estudantes público alvo da educação especial. Portanto, tivemos que lidar com uma forma de ensinar totalmente diferente e buscarmos alternativas para organizar e viabilizar um trabalho que favorecesse a aprendizagem desses estudantes.

Sabemos que a educação especial não se trata somente de oferecer um conteúdo, primeiramente se busca o acolhimento, o conhecimento das possibilidades de aprendizagem desses estudantes e, também, o vínculo entre os mesmos e seus professores e essas alternativas nos foram tiradas no contexto da pandemia.

Entendemos que a escola promove o desenvolvimento pessoal, transmite conhecimentos, além de formar cidadãos conscientes de seus direitos e deveres, ou seja, deve realizar o acolhimento de todos os estudantes, adequando-se para garantir e respeitar os direitos de todos os estudantes. Vale ressaltar o que nos diz Padilha (2013, p. 88), "Conceitos como os de inclusão e exclusão não podem ser banalizados, simplificados, porque 
corre o risco de banalizar e simplificar as necessidades fundamentais do ser humano, em cada época e em determinados espaços, por determinadas condições”.

Dessa forma, buscamos neste texto, levantar quais são os desafios encontrados no contexto da pandemia do ensino comum pelos professores especialistas e professores regentes que trabalham escolarização de alunos com deficiência. De quem seria a responsabilidade por essa escolarização? Cabe somente ao professor regente da turma a escolarização? O professor especialista nesse contexto é um mero ajudante?

Para tanto, recorremos aos autores, que buscam, através de suas pesquisas, refletir sobre o atendimento no ensino remoto aos estudantes público alvo da educação especial.

\section{O ENSINO REMOTO E SEUS DESAFIOS}

Buscando uma reflexão sobre as possibilidades de aprendizagem dos estudantes público alvo da educação especial, no contexto da pandemia, enquanto estudantes com direitos ao ensino em todas as suas modalidades, percebemos que, mesmo com o discurso de uma escola inclusiva, nos deparamos com a impossibilidade de atuação efetiva da escola com relação às diferenças encontradas em sala de aula e podemos imaginar a dimensão que essa atuação não efetiva tomou durante a pandemia.

Conforme Magalhães 2020, pág. 205:

As transformações sociais que ocorrem no mundo em razão da pandemia da Covid-19, desde o início de 2020, têm ocasionado mudanças em diversas áreas da sociedade, de proporções ainda impossíveis de serem mensuradas. A necessidade da imposição de práticas de distanciamento social para o controle e redução do contágio da doença, impactaram drasticamente setores basilares da estrutura do capitalismo como a economia, a saúde e a educação.

Diante desses desafios, para que a inclusão se efetive, os dias atuais exigem que o professor seja capaz de organizar as situações de aprendizagem, considerando as possibilidades de aprendizagem, as tecnologias disponíveis para esses alunos e como os mesmos poderão se organizar para que a aprendizagem ocorra com um ensino a distância eficiente, tanto na comunicação com os estudantes como na acessibilidade desses conteúdos. 
Precisamos nos reinventar para proporcionar o acesso e continuar mantendo os vínculos entre professores e alunos, nem que seja por alguns breves instantes pela forma virtual, respeitando a suportabilidade dos alunos, bem como, em alguns momentos, auxiliando as famílias em suas demandas, sendo realmente pontes de sustentação emocional para alunos e famílias.

( SILVA;BINS;ROZEK,2020)

Portanto, isso implica a interlocução e alinhamento baseado em um trabalho em colaboração dos professores envolvidos no processo de aprendizagem dos estudantes com deficiência. Na verdade, a escola deve desenvolver um trabalho envolvendo equipe pedagógica, professores especialistas e professores do ensino comum, no que diz respeito à criação de recursos pedagógicos acessíveis e ao planejamento de atividades inclusivas para toda a turma.

Para que possamos refletir sobre a discussão de quem seria a responsabilidade da escolarização do estudante com deficiência no contexto escolar e durante a pandemia, esclarecemos que, por meio da legislação, podemos compreender que o profissional especialista em Educação especial, no contexto da sala de aula no ensino comum, é o que proporciona as intervenções necessárias, porém, sempre em colaboração ao professor regente para que o estudante desenvolva autonomia por meio de intervenções e adequações.

A lei 13.146 de 6 de julho de 2015, em seu capitulo 4 que trata da educação, no ART $28^{\circ}$, nos diz que "Incumbe ao poder público assegurar, criar, desenvolver, implementar, incentivar, acompanhar e avaliar:

III- atribui o desenvolvimento de: projeto pedagógico que institucionalize o atendimento educacional especializado, assim como os demais serviços e adaptações razoáveis, para atender às características dos estudantes com deficiência e garantir o seu pleno acesso ao currículo em condições de igualdade, promovendo a conquista e o exercício de sua autonomia;"(...) V - adoção de medidas individualizadas e coletivas em ambientes que maximizem o desenvolvimento acadêmico e social dos estudantes com deficiência, favorecendo o acesso, a permanência, a participação e a aprendizagem em instituições de ensino;(...) XVII - oferta de profissionais de apoio escolar;(...) (BRASIL, 2015).

Porém, percebemos que o acompanhamento de um especialista em sala de aula, ou até mesmo de uma sala de recursos na escola, se torna a única possibilidade, em muitos casos, de o estudante receber orientação. Observamos que ainda é comum, no dia-a-dia do ensino comum, professores regentes alegarem falta de conhecimento e preparo para 
trabalhar com os estudantes público alvo da educação especial, deixando a cargo somente de professores especialistas a incumbência de sua aprendizagem.

Não podemos deixar de ressaltar que os professores especialistas também encontram dificuldades no contexto da sala de aula. Segundo Machado (2013, p. 133), uma das dificuldades encontradas por profissionais de apoio entrevistados por ele é o "de manter uma ação conjunta com os professores de classe regular e, que estes, delegam aos profissionais de apoio todo o esforço educativo dos estudantes com deficiência".

Entretanto, entendemos que o professor regente é o responsável pelo aprendizado de toda uma turma e que, em parceria com o professor especialista, pode estabelecer articulação desses saberes por estarem no mesmo espaço de aprendizagem, mesmo que remotamente. A articulação, neste contexto, se daria na medida em que as necessidades educacionais dos estudantes com deficiência fossem atendidas.

Contudo, a inclusão escolar na pandemia requer a continuidade dos esforços de educadores, ao longo desses anos, em promover a aprendizagem, recursos e possibilidades de participação dos estudantes público alvo da educação especial nos contextos do ensino comum. É responsabilidade de todos os educadores a escolarização de todos os alunos, independente de suas necessidades educacionais, sejam eles especialistas ou não.

Desta forma, e com esse intuito, não teríamos dúvida sobre de quem seria a incumbência de promover ações para a escolarização de estudantes público alvo da educação especial em todos os contextos educacionais.

\section{CONSIDERAÇÕES FINAIS}

A inclusão escolar de alunos com deficiência, mesmo antes da pandemia, já nos trazia desafios importantes, como a busca por estratégias, materiais diferenciados e ações em sala de aula que levassem esse alunado a efetiva aprendizagem. Nesta situação do ensino remoto, os desafios só mudaram de contexto e se tornaram ainda maiores.

Mesmo com todos os avanços tecnológicos que dispomos para as aulas remotas, o aluno da educação especial, na maioria das vezes, tem limitações no contexto familiar, 
sejam elas de acesso à internet, possibilidade de um orientador na família e muitos outros problemas observados pela comunidade escolar.

Embora o empenho em se organizar para o ensino remoto, os professores, tanto os do Ensino Comum como os profissionais especialistas em Educação Especial, se depararam com situações conflitantes nas aulas online, ausência de recursos e acessibilidade. Esses fatores tornaram esse período muito desafiador.

Diante disso, percebemos que a presença de um professor especialista, como apoio, é vista como uma possibilidade de solução para determinados problemas enfrentados pelos professores regentes no contexto da sala de aula e esta concepção pode ser vista como uma expectativa, não só do professor do Ensino Comum, mas de todos os funcionários da escola, pois os mesmos se empenharam muito para que materiais chegassem até seu aluno. As atividades foram pensadas de forma a favorecer e possibilitar a aprendizagem e isso requer o conhecimento especifico das possibilidades de aprendizagem do aluno da educação especial.

Entendemos, diante dos apontamentos dos autores pesquisados neste trabalho, que todos os meios elaborados pelos profissionais envolvidos no processo de inclusão do estudante com deficiência no Ensino Comum durante o ensino remoto, devem ter como prioridade a consideração sobre o papel da escola e de como está sendo realizado este trabalho, cada qual em suas funções e deveres de educadores.

Sabemos que, a forma colaborativa de se efetuar a inclusão tira a responsabilidade de um profissional somente e passa a incluir todos envolvidos no contexto escolar desse aluno com deficiência. Assim, o profissional especialista em Educação Especial, que apoia a escola em sala de aula comum, deixa de ser mero um ajudante e passa a ser protagonista de um ensino, que busca a escolarização de todos os alunos, enquanto participa efetivamente de todos os projetos da escola.

Todas essas possibilidades de reestruturação, do contexto da inclusão na perspectiva de um trabalho colaborativo no Ensino comum, podem nos habilitar para enxergarmos o aluno em outra dimensão, acreditando que, mesmo com as necessidades decorrentes de 
sua deficiência ou contexto familiar, ele poderá se desenvolver dentro de suas possibilidades e os educadores envolvidos serem responsabilizados juntos pelo seu sucesso.

Esse trabalho, portanto, requer observação constante por parte das autoridades e gestores para que seja contemplado em políticas públicas e futuras legislações voltadas à Educação Especial, trazendo visibilidade ao trabalho desenvolvido pelos especialistas em Educação Especial e conhecimento sobre esse trabalho pelos demais envolvidos no processo de escolarização desse público alvo.

\section{REFERÊNCIAS}

BRASIL. Lei Federal 13.005, de 25 de junho de 2014. Aprova o Plano Nacional de Educação - PNE e dá outras providências. Brasília, DF, 25. Jun. 2014. Disponível em: < http://www.planalto.gov.br/ccivil_03/_ato2011-2014/2014/lei/113005.htm>. Acesso em: 13/07/2018.

. Secretaria de Educação Especial. Política Nacional para Educação Especial na Perspectiva da Educação Inclusiva. Brasília: MEC, 2008.

. Conselho Nacional de Educação. Câmara de Educação Básica. Resolução CNE/CEB n. 2, de 11 de setembro de 2001. Brasília: CNE/CEB, 2001.

CARMO, Apolônio A. do. Inclusão Escolar: Roupa nova em corpo velho- Rev. Integração (MEC/SEESP), nº 23, p.43-48, 2001.

FERNANDES, Michele da S. G.; WEBER, Alice G.; FARIAS, Aline F.; PEREIRA, Josefa Lídia Costa. O Ensino Colaborativo e a Inclusão. In: XII Congresso Nacional de Educação-Formação de professores, complexidade e trabalho docente. PUCPR-Curitiba-PR -2015, p.2.647-2.655.

FERREIRA, Bárbara Carvalho; MENDES, Enicéia Gonçalves; ALMEIDA, Maria Amélia; Del PRETTE, Zilda Aparecida PEREIRA. Parceria Colaborativa: descrição de uma experiência entre o ensino regular e especial. Revista do Centro de Educação/ Cadernos,UFSM, n.29,Edição 2007, SP Disponível em:<http://coralx.ufsm.br/revce/ ceesp/2007/01/a1.htm>. Acesso em setembro de 2018.

FONTES, Rejane de Souza; PLETSCH, Márcia Denise; BRAUN, Patricia; GLAT, Rosana. Estratégias pedagógicas para a inclusão de alunos com deficiência intelectual no ensino regular. In: Rosana Glat et al.(org.) Educação inclusiva: cultura e cotidiano escolar. 2. Ed.-Rio de Janeiro. Ed. Sete Letras, 2013, p.79-96. 
MARIN, Márcia. BRAUN, Patrícia. Ensino Colaborativo como pratica de inclusão escolar. In---; GLAT, Rosana \& PLETSCH, Márcia Denise. (Orgs.). Estratégias Educacionais Diferenciadas para alunos com necessidades especiais. Ed. UERJ, Rio de Janeiro, 2013, p.58.

MACHADO, Adriana Marcondes. Educação Inclusiva: De quem e de quais práticas estamos falando? In: BAPTISTA, Cláudio Roberto et al. (Org.). Inclusão e escolarização: múltiplas perspectivas. Porto Alegre: Mediação, 2009, P. 127-136.

MAGAlHÃES, Tamara França de Almeida. A escolarização do estudante com deficiência em tempos de pandemia da covid-19: tecendo algumas possibilidades. Revista Interinstitucional Artes de Educar. Rio de Janeiro, V. 6 - N. Especial - pág. 205 - 221 (jun. - out. 2020): "Educação e Democracia em Tempos de Pandemia". DOI: https://doi. org/10.12957/riae.2020.53647206

PACHECO, José. Caminhos para a inclusão: um guia para o aprimoramento da equipe escolar. Porto alegre: Artmed, 2007.p. 15.

PADILHA, Anna Maria Lunardi. O que fazer para não excluir Davi, Hilda, Diogo. Políticas e Práticas de Educação Inclusiva. $4^{\circ}$ ed. Campinas: Autores Associados, 2013, p.85-111.

PLETSCH, Márcia Denise. GLAT, Rosana. Plano Educacional Individualizado (PEI): um diálogo entre as práticas curriculares e processos de avaliação escolar. In---; GLAT, Rosana \& PLETSCH, Márcia Denise. (Orgs.). Estratégias Educacionais Diferenciadas para alunos com necessidades especiais. Ed. UERJ, Rio de Janeiro, 2013, p. 20.

SILVA, Karla Fernanda Wunder da; BINS, Katiuscha Lara genro; ROZEK Marlene. A educação especial e a covid-19: aprendizagens em tempos de isolamento social. Interfaces Científicas • Aracaju $・$ V.10・N.1・p. $124-136 \bullet$ Número Temático - 2020

VILARONGA, Carla Ariela Rios; MENDES, Enicéia Gonçalves. Ensino Colaborativo para apoio à inclusão escolar: práticas colaborativas entre os professores. Ver. Bras. Est. Pedagog. (online), Brasília, v.95, n. 239, p. 139-151, jan/abr. 2014. 


\title{
CAPÍTULO 2
}

\section{IDENTIDADE E REPRESENTAÇĀO:}

\section{UMOLHAR SOBRE A EXCLUSĀO}

EO PRECONCEITO EM RELAÇĀO

\section{AO IA ALUNOIA INDÍGENA NA EDUCAÇĀOSUPERIOR}

\author{
Irení Aparecida Moreira Brito ${ }^{1}$
}

$1 \quad$ Mestre em Linguística pela Universidade Federal de Mato Grosso do Sul - UFMS. Técnica em Assuntos Educacionais na Universidade Estadual de Mato Grosso do Sul - UEMS. Integrante do CEPEGRE-UEMS e do Grupo de Estudo e Pesquisa em Estudos Culturais, Semióticos e Fronteiriços GESC-UEMS. ireni@uems.br. https://orcid.org/0000-0002-0945-0484 
Resumo: Neste texto, busca-se demonstrar, por meio de uma análise discursiva, sobre a exclusão e o preconceito em relação ao/a acadêmico/a indígena, ingressantes por meio do regime de cotas na Universidade Estadual de Mato Grosso do Sul - UEMS, destacando-se aspectos como identidade e representação. Considerando-se os objetivos da análise, optou-se pelos Estudos Culturais e pela Análise Crítica do discurso como aparato teórico-metodológico. O corpus deste trabalho foi produzido, a partir da realização de entrevistas semiestruturadas, momento em que os/as pesquisadores/as perceberam alguns fenômenos discursivos que demonstravam marcas que reveladoras de preconceito e exclusão em relação às entrevistadas, marcas estas que influenciaram o olhar dessas egressas sobre a Universidade e sobre os sujeitos que nela atuam. Os resultados demonstraram que a construção identitária dos sujeitos em questão foi influenciada pela luta para se constituírem enquanto "Ser" e sujeito indígena, num contexto por preconceito, discriminação e exclusão.

Palavras-chave: Exclusão. Discurso. Identidade. Representação. Indígena.

\section{CONSIDERAÇÕES INICIAIS}

Neste texto, busca-se refletir sobre o processo de inclusão na educação Superior, a partir de aspectos como identidade e representação, destacando o olhar sobre a exclusão e o preconceito em relação ao/a acadêmico/a indígena, ingressantes por meio do regime de cotas na Universidade Estadual de Mato Grosso do Sul - UEMS. Trataremos da análise da dimensão discursiva desse processo. Não abordaremos a política de cotas, mas sim os discursos produzidos pelos sujeitos cotistas acerca do contexto acadêmico. Buscaremos demonstrar como esse sujeito vê o ambiente universitário, suas impressões sobre o "outro" e sobre como são tratados por esses "outros". Buscaremos por marcas discursivas que revelem a visão do/a egresso/a cotista sobre a inclusão/exclusão no ambiente universitário. Para isso, serão analisados os discursos de duas alunas cotistas indígenas, objetivando verificar como essas se sentem/sentiram dentro dos cursos de graduação da UEMS e se há o sentimento de inclusão ou exclusão por parte dos sujeitos analisados.

Quando abordamos o processo de inserção social do estudante cotista, nos deparamos com a problemática da exclusão. A partir da análise de um corpus de narrativas produzidas pelas duas egressas, essa questão que envolve a questão exclusão dos alunos cotistas fica evidente. Assim, o foco da análise, aqui apresentada, recai sobre o como essas cotistas se 
veem dentro do contexto universitário, nos cursos de graduação da UEMS, ressaltando-se que esse modo de ver é revelado nos discursos produzidos pelas mesmas. Nesse sentido, pretende-se demonstrar em que medida os discursos dos cotistas, nesse caso duas egressas indígenas, revelam uma exclusão que, muitas vezes, passa despercebida, ou velada, no ambiente acadêmico.

Considerando-se os objetivos da análise aqui apresentada, optamos pelos Estudos Culturais e pela Análise do discurso como base teórica transdisciplinar que possibilita uma reflexão sobre as representações que as egressas indígenas, que optaram pelo regime de cotas, atribuem à Universidade e aos sujeitos que nela atuam, a partir dos seus discursos.

"Transdisciplinarizar é analisar um enunciado como efeito dos discursos, cuja singularidade só pode ser notada mediante determinadas condições de produção, ou de enunciação" (GUERRA E ALMEIDA, 2015).

A análise do Discurso considera o sujeito como um ser social e discursivo. Os Estudos Culturais consideram a exclusão como uma marca do binarismo, uma construção social que ocorre num contexto marcado por relações de poder. Os Estudos Culturais tratam da diversidade que cada cultura apresenta na produção cotidiana de sua história em um tempo e espaço determinados, enfocando as interações interculturais estabelecidas na contemporaneidade e os desdobramentos políticos gerados tanto no âmbito da solidariedade quanto no plano da dominação.

Ao relacionarmos a questão da dominação ao discurso, remetemo-nos a Foucault (2014) para quem a produção do discurso é controlada, selecionada, organizada e redistribuída por alguns procedimentos que têm por função conjurar seus poderes e perigos. Na esteira desse autor, destacamos que os discursos aqui analisados, dos quais emergem sentidos que revelam uma representação de si, constituem-se numa materialidade controlada por um ambiente universitário, revelador de ralações de poder e atravessamentos que interferem na representação que os sujeitos fazem de si.

A questão norteadora das reflexões apresentadas nesse texto é: quais representações sobre o ser indígena na educação superior surgem no discurso das duas egressas 
indígenas, cujas narrativas são aqui apresentadas? A partir dos posicionamentos desses sujeitos, buscamos traçar o percurso discursivo das narrativas de modo a investigar as representações e identidades ali construídas/reconstruídas e como essas representações e identidades revelam processos de inclusão/exclusão no ambiente universitário.

Este texto apresenta, inicialmente, alguns aspectos contextuais sobre a temática em questão. Logo em seguida destacam-se as considerações teóricas, a partir dos pressupostos teóricos da análise do discurso e dos Estudos Culturais. Logo em seguida, apresentam-se algumas reflexões sobre os discursos produzidos no contexto da Universidade Estadual de Mato Grosso do Sul - UEMS, no que se refere às identidades e às representações.

\section{ASPECTOS CONTEXTUAIS}

Os discursos emergem e geram sentidos nas práticas sociais e na história de cada sujeito ou instituição. Assim, faz-se necessário abordarmos alguns aspectos sobre o contexto sócio-histórico que deu origem às materialidades discursivas aqui analisadas.

Primeiramente, cabe enfatizar que a sociedade brasileira é formada por uma das maiores diversidades do planeta, somente quanto aos povos indígenas, o Brasil conta, atualmente, com 305 etnias, que falam 274 línguas diferentes, segundo o censo do Instituto Brasileiro de Geografia e Estatística (IBGE, 2010), que afirma, ainda, que o Estado de Mato Grosso do Sul - MS - configura-se como o segundo Estado da federação com o maior número de indígenas, totalizando 77.000 (setenta e sete mil) indivíduos divididos em 08 etnias e, algumas delas, em intensa inserção no entorno regional, como ocorre no município de Dourados-MS, onde se localiza a sede da Universidade Estadual de Mato Grosso do Sul - UEMS.

Além da UEMS, o município de Dourados-MS - conta com outras Instituições de Ensino Superior - IES, como a Universidade Federal da Grande Dourados - UFGD, o Centro Universitário da Grande Dourados - UNIGRAN e a Anhanguera Educacional. Tais IES são frequentadas por indígenas de todo o estado, além de alguns que vêm de outros Estados, devido ao Sistema de Seleção Unificada - Sisu, que possibilita a mobilidade acadêmica em nível nacional. Além disso, a região sul do estado é onde se encontra o 
maior número de indígenas das etnias Guarani Nandeva e Guarani Kaiowá, além de alguns da etnia Terena, contando com aldeias que chegam a ter cerca de 15 mil indígenas, como é o caso das aldeias Jaguapiru e Bororó, localizadas a menos de 10 quilômetros do centro de Dourados, MS.

Muitas indígenas deixam suas casas na aldeia/reserva e, pela primeira vez, vão morar na cidade e enfrentam desafios diferentes do que estavam acostumados em seu cotidiano, inclusive com relação aos gastos que se tem para ser estudante universitário na atualidade, com livros (ou cópias), aluguel, alimentação, vestuário, além do transporte que, especificamente no caso de Dourados, as universidades públicas são localizadas fora do perímetro urbano, distantes, aproximadamente, 15 quilômetros do centro da cidade.

Destacamos que as ações afirmativas para as indígenas foram institucionalizadas no Mato Grosso do Sul, em 2002, a partir da publicação da Lei n. 2.589, de 26/12/2002, que estabeleceu reserva de vagas para estudantes indígenas, na Universidade Estadual de Mato Grosso do Sul. Após a publicação desta normativa, a UEMS regulamentou internamente o Sistema de Cotas para indígenas, por meio da Resolução COUNI-UEMS n. 241/2003, que dispõe sobre a oferta das vagas em regime de cotas dos cursos de graduação da UEMS, reservando $10 \%$ das vagas ofertadas na instituição para os candidatos/as autodeclarados/ as indígenas.

Além do acesso por meio de cotas, existem também alguns programas destinados a apoiar a permanência de acadêmicos/as indígenas da UEMS, como o Programa de Assistência Estudantil (PAE), que conta com bolsa permanência, auxílio alimentação e auxílio moradia, o Programa Vale Universidade Indígena (PVUI) entre outros programas. A UEMS conta, ainda, com a Divisão de Inclusão e Diversidade (DID - vinculado à PróReitoria de Extensão, Cultura e Assuntos Comunitários - PROEC), que é o órgão que acompanha as políticas de inclusão social e o combate à exclusão dos grupos histórica e socialmente discriminados dentro da universidade, além de promover o assessoramento e apoio aos estudantes, visando à prevenção da discriminação de gênero, classe, raça, etnia, orientação sexual e de pessoas com necessidades educacionais especiais naquela Instituição ${ }^{1}$.

1 Disponível em: <http://inclusaouems.blogspot.com.br/> Acesso em: out./2021. 
A universidade conta, também, o programa "Rede de Saberes: permanência de indígenas no Ensino Superior", que de acordo com Brostolin e Cruz (2010), foi gestado no final de 2005, em parceria com o Projeto Trilhas do Conhecimento, com recursos da Fundação Ford e gerenciado pelo Laced/Museu Nacional da Universidade Federal do Rio de Janeiro (UFRJ). Sabendo do contexto e da problemática vivenciada pelos povos indígenas ao ingressarem num curso de graduação, o projeto tinha como objetivo favorecer a permanência dos acadêmicos na educação superior, uma vez que as dificuldades enfrentadas eram muitas e ocorriam de diversos modos, como enumera os autores:

[...] a permanência é um grande problema, já que as dificuldades em manterse nos cursos/IES são muitas: de ordem financeira: material didático (livros, xerox), alimentação, transporte, moradia; de ordem pessoal acadêmica: defasagem de conteúdos, de exclusão digital, de cumprimento de prazos e horários, de compreensão de textos científicos, o que exige um pensamento mais intelectualizado valorizado pela academia, diferente do estilo de aprendizagem perceptivo do sujeito indígena que aprende através de uma pedagogia indígena comunitária, na relação com a terra, seus pares e com a natureza; e de ordem socioafetiva: dificuldade no relacionamento com colegas e professores devido à timidez e reserva, um traço característico da personalidade do aluno indígena e, muitas vezes, a discriminação e o preconceito explícito ou implícito em atitudes de desvalorização e zombarias (BROSTOLIN; CRUZ, 2010, p. 37).

Os discursos, objetos desta análise, foram produzidos durante a realização de uma etapa do curso de formação de professores indígenas Guarani e Kaiowá no nível de magistério, denominado Ara Vera (Tempo Iluminado, em língua Guarani) realizada no município de Dourados, o qual as acadêmicas indígenas participavam como ouvintes e colaboradoras eventuais, visto que o referido curso, segundo Nascimento e Vieira (2011), é bastante relevante para a efetivação de um currículo e de uma escola especifica e diferenciada, orientada por uma pedagogia intercultural, em sua vertente crítica.

Como metodologia utilizou-se a entrevista semiestruturada na qual tínhamos como principal indagação a sua percepção quanto ao ingresso e a sua passagem pela universidade, incluindo o sistema de cotas, as estratégias de permanência e as relações com o outro no ambiente acadêmico, muitas vezes, marcadas pelo preconceito.

O corpus deste trabalho foi produzido, a partir de gravações das entrevistas, momento em que os/as pesquisadores/as perceberam alguns fenômenos discursivos que demonstraram, em muitos casos, marcas que revelam o preconceito e a discriminação 
sofridos pelas entrevistadas, marcas estas que influenciaram o olhar dessas acadêmicas sobre a Universidade e sobre os sujeitos que nela atuam.

As produtoras dos discursos em análise neste trabalho, denominadas entrevistada 01 e entrevistada 02, são indígenas da etnia Terena e ingressaram na UEMS pelo sistema de cotas para índios. A entrevistada 01 cursou apenas o ensino médio em escola não indígena, visto que na aldeia em que morava não era oferecida essa modalidade educacional e seria necessário que ela fosse estudar em um distrito ou em uma escola particular, por isso se mudou para Dourados-MS. O primeiro ingresso na educação superior se deu por meio de uma ação afirmativa que era desenvolvida pela Fundação Nacional do Índio - FUNAI e por uma Instituição de Ensino Superior - IES - privada, onde era oferecida uma bolsa de estudos integral para as indígenas matriculadas. Porém a mesma não conseguiu se adaptar, vindo a participar do processo seletivo da UEMS, para o curso de licenciatura em letras.

A entrevistada 02 estudou na escola indígena até a $5^{\mathrm{a}}$ série (atual $6^{\circ}$ ano), pois não eram oferecidos os demais níveis de ensino na aldeia onde residia. Os pais não tinham condições de pagar escola particular, tendo sido obrigada a ir morar em sistema de internato numa escola no distrito próximo a sua aldeia, vindo a trabalhar e estudar na escola, que era de cunho evangélico, onde estudou até concluir o ensino fundamental e cursou os dois primeiros anos do ensino médio. Mudou-se para Dourados-MS, onde concluiu o ensino médio numa escola não indígena que oferecia a modalidade de ensino da Educação de Jovens e Adultos - EJA.

\section{DISCURSO, IDENTIDADE, REPRESENTAÇÃO E SUJEITO}

Considerando os objetivos da análise aqui apresentada, optamos pelos Estudos Culturais e pela Análise Crítica do discurso como base teórica transdisciplinar que possibilita uma reflexão sobre as representações que as egressas indígenas, que ingressaram pelo regime de cotas, atribuem à Universidade e aos sujeitos que nela atuam, a partir dos seus discursos.

"Transdisciplinarizar é analisar um enunciado como efeito dos discursos, cuja singularidade só pode ser notada mediante determinadas condições de produção, ou de enunciação" (GUERRA E ALMEIDA, 2015). 
Destacamos que o discurso é uma prática social na qual o indivíduo se posiciona como sujeito. Ele se constitui, se enxerga e se identifica por meio das relações sociais e culturais que estabelece ao longo da vida e na relação com as instituições as quais está vinculado e que a elas se submete como: escola, Igreja, família, Universidade.

É a partir desse lugar que o sujeito se posiciona no mundo, constrói seus valores, ideologias, identidades e representações, que são materializadas por meio do discurso.

É importante destacar que "a identidade resulta das representações ou imagens que cada um faz de si e do outro e que essas representações partem sempre do outro, pois nos vemos através do olhar do outro - outro amigo, outro família, outro professor, outros livros" (CORACINI, 2007).

Dessa forma, quando falamos em representação discursiva, nos remetemos à noção de poder, que é a base de todas as representações que construímos no cotidiano de nossas vivências. Quando falamos de poder no contexto discursivo, nos remetemos às palavras de Teun Van Dijk (2012, p. 10), para o qual a Análise de Discurso "não está interessada em qualquer tipo de poder, mas especificamente, se concentram no abuso de poder, isto é nas formas de dominação que resultam em desigualdades e injustiças sociais".

Assim, o discurso é uma prática social de representação e de significação do mundo. Ainda conforme Van Dijk (2012, p. 10), “o discurso não é analisado apenas como um objeto verbal autônomo, mas também como uma interação situada, como uma prática social ou como um tipo de comunicação, numa situação social, cultural, histórica ou política".

De acordo com o pensamento desse autor, o conceito de poder resume-se em controle, isto é, a habilidade de controlar as ações e mentes de outros. Dessa forma, o poder social é entendido como grupo.

A relação entre discurso e poder é complexa. Os atores sociais mais poderosos, segundo a definição apresentada, são aqueles que possuem os meios e recursos para influenciar as ações e mentes de outros. Entretanto, como as ações são controladas pela mente, grande parte do poder - salvo aquele exercido através do uso da força e de sanções implica no controle da mente, que é exercido através do discurso, especialmente do discurso 
público da mídia, das instituições educacionais e políticas. Tal controle é tipicamente exercido pelo não fornecimento de informações, pelo fornecimento de informação limitada, ou enviesada sobre determinado evento para sujeitos que não possuem acesso a fontes alternativas de informação e que, generalizando a partir desse modelo, formarão novos modelos mentais enviesados reproduzindo percepções e ações.

“A produção do discurso é ao mesmo tempo controlada, selecionada, organizada e redistribuída por certo número de procedimentos que têm por função conjurar seus modelos e perigos, dominar seu acontecimento aleatório, esquivar sua pesada e temível materialidade" (FOUCAULT, 2014, p. 8-9).

Considerando esse controle exercido pelo discurso, percebemos que as representações que os sujeitos constroem da realidade são, de algum modo, determinadas pelas estruturas de poder predominantes no meio, na sociedade em que se encontram e desenvolvem sua prática diária. Portanto, os discursos sofrem interdições (FOUCAULT, 2014), nem tudo é dito, exteriorizado. As circunstâncias determinam o que pode ser dito. No caso em questão, as representações são produzidas pelas relações de poder existentes no ambiente Universitário. As entrevistadas constroem suas identidades, suas representações de si e do outro a partir das relações e das trocas culturais estabelecidas nesse contexto.

Nesse ponto, em que abordamos identidades como uma soma das relações e das trocas culturais, destacamos o entrelaçamento da Análise do discurso e dos estudos culturais como metodologia de análise e produção de sentidos. É nesse momento que o jogo das diferenças se torna essencial na construção de uma nova política de construção de significados. Significados esses que produzem identidades, contribuindo para que os envolvidos nesse jogo percebam-se como sujeitos de ações e que podem, inclusive, deslocar sua posição dentro das relações de submissão, construídas ao longo da história.

Ao tratar de identidades e questões de inclusão, (CORACINI, 2007, p. 112) pondera que "a palavra passa pelo sujeito (sujeito de linguagem), atravessa-o, faz corpo, constitui-o, este, $[\ldots]$ mais se diz do que diz, mais se apresenta do que apresenta ou informa".

Dessa forma, ao ser atravessado por suas histórias e experivivências (termo cunhado por Edgar Nolasco, em sua abordagem sobre o discurso fronteiriço), o sujeito se revela 
pela linguagem, apresenta mais sobre si, do que sobre ouro, revelando, discursivamente suas identidades, sua representação de si.

Sendo o sujeito um ser social, ou seja, o sujeito sociológico, de acordo com Hall (2006), cuja é identidade é formada na interação entre o eu e a sociedade, concebe-se esse sujeito como um ser que é "formado e modificado num diálogo contínuo com os mundos culturais ‘exteriores' e as identidades que esses mundos oferecem” (HALL, 2006, p.11).

Assim, a constituição identitária é um processo constituído pelas relações do sujeito com as pessoas, os valores, os sentidos, os símbolos e a cultura, pois, a identidade, nessa concepção de sujeito sociológico, “preenche o espaço entre o 'interior' e o 'exterior' entre o mundo pessoal e o mundo público (HALL, 2006, p. 11).

É nesse sentido que compreendemos os povos indígenas na atualidade, como sujeitos que interagem com a sociedade envolvente, realizam trocas culturais e sociais, demonstrando que acompanham as evoluções da sociedade e que muito contribuem (e contribuíram) para a melhoria na qualidade de vida das pessoas e do planeta de modo geral.

Nessa perspectiva, a Análise do Discurso, assim como os Estudos Culturais concebe o sujeito e as relações sociais de forma descentrada. Não o considera numa perspectiva, cartesiana, plana. Portanto, essas duas abordagens, utilizadas como modelo teórico nessa análise, concebem o sujeito numa única perspectiva - como um ser social, um "ser do discurso", disperso, fragmentado, múltiplo, assim como suas identidades e como as representações que faz da realidade à sua volta.

\section{MARCAS IDENTITÁRIAS E REPRESENTAÇÃO NOS DISCURSOS PRODUZIDOS POR EGRESSAS INDÍGENAS DA UEMS}

As identidades constroem-se na interação do sujeito com o outro, e se ressignificam nas práticas sociais, sendo, uma dessas práticas, a linguagem. Esse fato ocorre porque, de acordo com Ferreira (2009, p. 45-46):

A experiência psicológica encerra um caráter de construção permanente, em que as especificidades das experiências pessoais determinam a maneira como 
o indivíduo constrói suas referências de mundo, incluindo aquelas através das quais ele pode reconhecer-se como um determinado indivíduo - sua identidade.

Nesta análise, essa construção aparece na relação que as entrevistadas estabelecem na sua vida acadêmica, nas interações realizadas na Universidade. Podemos observar em seus discursos que havia sempre uma busca por se sentir como igual, como afirma Coulon (2008) sobre o estudante que ingressa na universidade. Ele precisa adquirir o status de igual, através da compreensão e decodificação dos códigos inerentes à cultura universitária, que fará com que ele se aceite como universitário. No caso das indígenas, há ainda a necessidade de se fazer aceitar como alguém que detenha conhecimento e capacidade de aprendizado, visto que enfrentam muito preconceito, primeiramente por ser indígena, num Estado onde a mídia e a sociedade desqualificam esta condição étnica, mesmo sendo o segundo Estado do país com maior número de indígenas e, por outro lado, são menosprezadas por terem entrado pelo sistema de cotas, pois, na universidade, há um discurso cotidiano que propaga a ideia de que os indígenas desenvolvem um aprendizado mais lento.

Podemos, então, perceber esse processo de busca por pertencimento acadêmico, a aquisição do "status de igual", por meio de discursos como "tratavam a gente igualmente", "respeitavam a nossa presença" ou ainda quando alguns, poucos, professores davam "oportunidade para a gente comentar um pouco da aula dele".

A entrevistada 01 relata uma passagem que reflete esse sentimento, pois ela ingressou, inicialmente, numa instituição privada na qual não se sentiu à vontade, buscando, assim, ingressar na IES pública que dispunha de cotas para indígenas e onde poderia se sentir mais à vontade. Ela afirma que conseguiu se adaptar à nova instituição "se sentindo mais em casa". Esse discurso revela que apesar de também existir preconceitos e dificuldades na IES pública, ela sentia-se mais aceita, visto que na instituição particular sentia-se envergonhada pela forma de ser e de se vestir.

Esse fato demonstra a falta de interação entre a acadêmica e os demais sujeitos. Ressaltou ainda que não conseguiu se socializar com os colegas durante os dois anos que permaneceu na IES privada, enquanto que na UEMS a interação foi bem maior, tanto pelo maior número de indígenas, como pela maior abertura dos colegas que frequentavam a universidade. Essa afirmação aprece nas seguintes expressões: 
Se sentindo mais em casa.

Eles eram assim muito chiques e eu não, entendeu, e eles também não se aproximavam de mim, eu tinha que pedir para entrar nos grupos, em nenhum momento eles chamavam, vem cá colega, entra no grupo.

Por outro lado, é possível perceber, em seu discurso, que há situações em que esta tentativa de se igualar aos não indígenas, se torna infrutífera, a exemplo do episódio em que relata o constrangimento quando, em sala de aula, abordavam-se os "conflitos agrários" da região, que envolviam os indígenas, afirmando que poucos falavam sobre o assunto. Percebe-se que a expressão "respeitavam a nossa presença", utilizada pela entrevistada, demonstra que ela não se identificava, não interagia com os demais grupos.

Em alguns momentos do seu discurso, a indígena, ao mesmo em que afirma não haver muito preconceito na Instituição Pública, revela marcas que denotam a existência desse preconceito, como demonstram os trechos seguintes:

Quando entrei na universidade, mudou assim no meu modo de pensar, o que eu quero, de ver minha comunidade, pra mim minha comunidade não sofria, entendeu, não sofria preconceito, não sofria discriminação, igual como eu vejo hoje né, sobre a questão de terras, é bem diferente a universidade mudou assim completamente meu ponto de vista.

Uns falam que é mais para o curso de direito, sentem muito essa pressão.

Acho que ela sentiu um pouco também, no curso de pedagogia.

No discurso da entrevistada, aparecem algumas marcas de afirmação identitária como: "quando entrei na Universidade mudou assim meu modo de pensar", "pra mim minha comunidade não sofria, entendeu, não sofria preconceito", "igual como eu vejo hoje né", "mudou assim completamente meu ponto de vista". Essas marcas mostram que sua identidade indígena foi afirmada a partir do contato com o não índio.

Esse modo de se ver, a partir da relação com o outro, é influenciado por vários aspectos. A indígena, muitas vezes, tem sua imagem vista de forma negativa, prejudicialmente potencializada pela ênfase negativa que é dada pelo discurso midiático sobre os povos indígenas que os colocam como criminosos, vagabundos e violentos.

Essa construção midiática influencia na formação identitária das indígenas, pois, este tipo de relação social, fundamentada na indução midiática, interfere na forma como as acadêmicas indígenas se percebem e são percebidos no ambiente universitário. 
Pondera-se que, possivelmente, a entrevistada não tenha percebido o quanto outras pessoas dentro da universidade tiveram com ela atitudes racistas ou preconceituosas, fato que pode ser inferido quando diz que: "não era chamada para formar os grupos de trabalho, tendo que pedir para entrar nos grupos" ou, ainda, quando foi influenciada a mudar de curso, por parte da diretora da escola em que dava aula de língua materna indígena.

Outra situação reveladora de preconceito é apontada pela entrevistada 02 , ao relatar uma situação ocorrida durante a realização de um estágio, nos últimos anos do curso, no qual se sentiu humilhada por ter sido considerada reprovada pela docente, por não ter participado da última das quatro aulas de regência a que o grupo teria que ministrar e, ao questionar a docente titular da disciplina, foi orientada, na semana seguinte, para fazer um novo planejamento para a aula de regência, sendo que seu grupo já havia elaborado tendo que fazer este novo planejamento no prazo de três dias e ministrar a aula de forma individual. Segundo a entrevistada, a docente se utilizou desse "artifício" para questionar sua capacidade de elaborar o planejamento e ministrar aula, como se ela não tivesse ajudado o grupo na atividade, grupo este formado por outros acadêmicos considerados pela indígena como "de elite". Porém a entrevistada tomou uma atitude que deixou a docente perplexa, em suas palavras:

Falei quer ver o que eu vou fazer? Fiz o projeto e mandei pra ela, eu mesma fiz, aí ela olhou e quando ela viu o projeto ela falou assim 'foi você mesmo que fez ou a fulana que era a líder do grupo ou ela te ajudou?' falei, não, foi eu que fiz. Aí ela falou assim, então nós vamos ver na hora da execução. Você acredita que eu voltei sozinha na escola pra executar esse plano de aula que ela duvidou que foi eu que fiz. Eu acho que eu me dei melhor fazendo sozinha do que com o grupo. E ela falou assim pra mim, é realmente foi você que fez. Ela duvidou que fosse eu. Isso no terceiro ano, já quase saindo da faculdade.

Destaca-se que, na fala acima, a entrevistada enfatiza, por diversas vezes, a palavra 'duvidou' no sentido de que o peso da dúvida da docente quanto a sua capacidade impactou na representação que a entrevistada faz de si. O fato foi bastante relevante no sentido de que "ficou gravado esse sentimento até os dias de hoje".

Destacamos que há uma marca de reafirmação identitária no discurso da entrevistada 02, na seguinte expressão: "me dei melhor fazendo sozinha do que com o grupo". Nessa fala ela demonstra que faz uma representação positiva de si. Ela se afirma enquanto sujeito de seu discurso, ao reafirmar sua identidade indígena. 
Em outros trechos de sua fala, a entrevistada vai demonstrando outros preconceitos enfrentados na Universidade e que colaboraram para a sua reafirmação identitária, como destacamos a seguir:

Os professores não estavam preparados para receber indígenas dentro da universidade [...] os professores hoje já acho que já está tão acostumado com índio na universidade que já estão mais familiarizados, mas assim a parte assim bem no comecinho a gente foi a primeira turma a gente sentiu muito isso, uma parte assim do preconceito mesmo, muito, muito forte, eu pelo menos senti muito isso.

Relatando a questão do preconceito sofrido, a entrevistada aponta que tal situação não era, especificamente, relacionada a elas, mas ocorria com acadêmicos negros também e partiam dos próprios colegas, na sala de aula ou nos corredores da universidade, inclusive desqualificando sua presença na instituição devido ao fato terem ingressado pelo sistema de cotas, como percebemos no trecho:

Não só eu como indígena, mas tive colegas negros, eles também sofriam esse
mesmo preconceito né, era visível na hora que a gente fazia os trabalhos o grupo
de trabalho eles sempre excluíam a gente. [...] Até os próprios alunos, nossos
colegas, faziam meio que, falavam assim, aí você entrou na universidade porque
você fez uma prova diferenciada, o que é totalmente errado, porque nós fizemos a
mesma prova dos não indígenas nós fizemos também, só foi garantido uma vaga
pra nós e até comentei uma vez com uma colega nossa, se fosse assim todas as
nossas provas dentro da sala seriam diferentes também, né, mas não é.

No trecho acima a indígena apresenta marcas que, novamente, reafirmam sua identidade. Ela não se sente inferior por ter entrado por meio do Regime de cotas já que diz: "porque nós fizemos a mesma prova dos não indígenas nós fizemos também”. Ela aponta que desde o primeiro até o último ano do curso de graduação sempre participou do mesmo grupo formado por indígenas e negros, visto que nenhum outro grupo os incluía nos trabalhos a serem feitos em sala de aula ou fora dela. E enfatiza que há discriminação no ambiente universitário e que os sujeitos que sofrem com essa colonialidade ${ }^{2}$ são os indígenas, os negros e os pobres, visto que, de alguma forma, estes são classificados como fora do padrão objetivado para cursar a educação superior no país.

2 A colonialidade significa o resquício dos efeitos da colonização, a saber: invasão, exploração, violência, subalternização, exclusão, discriminação, preconceito e racismo praticados pelos colonizadores europeus e que persistem mesmo após o fim do período colonial. 
Outro ponto a se destacar, no discurso dessa entrevistada, é o modo como ressignifica a discriminação e a violência, psicológica e física, sofrida pelas indígenas não só no ambiente acadêmico, mas em muitos outros espaços sociais. Fato que observamos no seguinte recorte de sua fala: "Eu aprendi a ser forte dentro da faculdade, aprendi a ter resistência, aprendi que a gente também tem seu valor, tem o modo de ser, que é uma coisa que a gente não foi ensinado", referindo-se à metodologia da educação escolar a qual foi submetida, nas escolas indígenas. Nesse discurso está implícito que as dificuldades enfrentadas pelas indígenas devem se tornar um incentivo para alcançar seus objetivos.

Outra marca positiva do discurso da entrevistada 02 refere-se à motivação para os estudos, perceptível quando diz que: "passou a estudar mais e para o desejo de, no futuro, continuar os estudos fazendo mestrado, para contribuir com a melhoria da qualidade da educação, principalmente quanto à educação escolar indígena".

Essas mudanças no modo de pensar das egressas indígenas e, consequentemente, em suas identidades, se deram a partir, e em conjunto, com a interação social advinda do ingresso na educação superior, local onde se encontram diversas pessoas cada uma com sua história, seu discurso, sua identidade. Possivelmente este tenha sido o impacto sentido pela entrevistada ao se relacionar com pessoas que tivessem pensamentos diferentes do seu, que lhe enxergava de forma diferente do modo como ela se via e percebia os seus iguais.

Baseando-nos, também, no que propõe Moita Lopes (2002, p. 15), para quem "a identidade é construída nas práticas discursivas situadas na história, na cultura e nas instituições", podemos afirmar que os discursos das egressas revelam uma identidade reafirmada, por meio da interação com o outro, com outras realidades sociais e coletivas. Isso ocorre porque a identidade se constrói a partir da alteridade, da relação do sujeito com o outro, a partir do olhar lançado sobre o outro e do olhar que o outro lança sobre mim, tratando-se de uma situação híbrida e de sujeitos híbridos. Sobre esse assunto, Hall (2003, p. 74) menciona que:

O hibridismo não se refere a indivíduos híbridos, que podem ser contrastados com os "tradicionais" e "modernos" como sujeitos plenamente formados. Trata-se de 
um processo de tradução cultural, agonístico uma vez que nunca se completa, mas que permanece em sua indecibilidade.

Por isso, vale salientar que a identidade é móvel, fragmentada, não é fixa, vai se alterando durante as relações, é uma identidade forjada nos espaços culturais, um processo híbrido, uma mistura. Esse hibridismo se refere ao fato de que os indivíduos se adaptam a culturas diferentes das suas e, assim, vão construindo/alterando sua identidade por meio da assimilação de culturas diferentes.

\section{CONSIDERAÇÕES FINAIS}

A partir da análise e das reflexões teóricas aqui abordadas, podemos afirmar que os discursos, por meio de marcas implícitas ou explícitas, revelaram aspectos do ser, do indivíduo. Mostraram o que cada sujeito pensa de si, ou seja, como esse sujeito se representa, se identifica. Portanto, a identidade é construída ao longo das vivências, das experiências que se tem durante vida, das relações que vão se estabelecendo, umas harmoniosas, outras conflituosas, mas que nos constituem e interferem na maneira como enxergamos o mundo, as outras pessoas e, principalmente, como enxergamos a nós mesmo, nossa comunidade, nossa gente, nosso chão.

Assim sendo, a análise demonstrou a existência de sujeitos e identidades atravessadas por contextos de exclusão ocorridos no ambiente universitário. Constatou-se, por meio de marcas presentes nos discursos, que as egressas indígenas, por serem de outra etnia não foram acolhidas, incluídas no contexto de sala de aula, no curso de graduação.

Quando abordamos discursos e situações discursivas, é inevitável não tratar da relação dialógica, do "lá" e "cá”, do "eu" e o "outro". Sendo o discurso uma prática social, nos propomos a desvendar os sentidos contidos nos discursos das duas indígenas, egressas da Universidade Estadual de Mato Grosso do Sul - UEMS.

Como todo discurso parte de um lugar, na Análise em questão os discursos partiram da reserva indígena da região de Dourados-MS e de um curso de graduação da UEMS, onde há conflitos e dificuldades relacionadas aos processos de inclusão, à aceitação do outro, daquele que foge ao padrão hegemônico que sempre prevaleceu nas Universidades 
e que, a partir das políticas de ações afirmativas, começa a ser alterado.

A lógica, até então vigente, começou a ser subvertida. Essa mudança aparece nos discursos, local onde se materializam as práticas sociais. Nas teias discursivas, revelam-se as marcas deixadas pela exclusão, aquela que ocorre por meio do simbólico, das palavras. Trata-se do "abuso de poder, um reflexo do "pensamento abissal", que ainda impera nas instituições, mesmo naquelas que têm a inclusão como base, inclusão que está normatizada, mas que, muitas vezes, não ocorre de fato.

Nesse sentido, constatamos nos discursos analisados há uma identidade marcada pela luta para se constituírem enquanto "Ser" e sujeito indígena, numa região marcada pelo preconceito e pela discriminação que ocorrem das mais diversas formas e que se utiliza de meios diversificados. Os principais veículos desses preconceitos são a mídia, a escola, a universidade, as instituições religiosas. Esses lugares determinam a ordem do discurso, que busca sempre uma colonização dos seres. Portanto, o modo como os discursos das egressas indígenas, denominadas neste trabalho como entrevistadas 01 e 02 , se constituem é determinado pelos lugares de onde elas vieram e por onde elas passaram, seu lugar de fala.

As marcas discursivas demonstram que, o preconceito que sofreram, embora muitas vezes deixassem transparecer que esse preconceito não existia, serviu para ressignificar suas identidades. Ao dizerem que quando eram discriminadas por ter entrado pelas cotas, reagiam dizendo que fizeram a mesma prova, é um fato que demonstra a reafirmação identitária, pois não se sentiam inferiores e, por isso, reagiam ao preconceito e todas as formas de exclusão.

Os discursos revelaram, ainda, que a interação social advinda do ingresso na educação superior, local onde se encontram diversas pessoas cada uma com sua história, sua visão de mundo, seu discurso, sua identidade, influenciou na maneira como as entrevistadas enxergavam os outros e a si mesmas. Percebemos que este foi o principal impacto sentido pelas entrevistadas ao se relacionar com pessoas que tivessem pensamentos diferentes do seu, que as enxergavam de forma diferente do modo como elas se viam e do modo como elas percebiam os seus iguais. Portanto a identidade e a representação que cada uma fez de si, ocorreu num processo dialético. 


\section{REFERÊNCIAS}

BROSTOLIN, M. R.; CRUZ, S. F. Educação e sustentabilidade: o porvir dos povos indígenas no ensino superior em Mato Grosso do Sul. Interações - Revista Internacional de Desenvolvimento Local. Campo Grande - MS, v. 11, n. 1, jan./jun., p. 33-42. 2010. Disponível em: $<\mathrm{http}: / /$ www.scielo.br/pdf/inter/v11n1/a04v11n1>. Acesso em: 10 jun. 2017.

CHARAUDEAU Patrick. Identidade Linguística, identidade Cultural: uma relação paradoxal. In: Discurso e (des)igualdade social. Gláucia Proença Lara, Rita Pacheco Limberti. São Paulo, Contexto: 2015.

COULON, A. A condição de estudante. A entrada na vida universitária. Tradução de GAIORGINA Gonçalves dos Santos. Sonia Maria Rocha Sampaio. Salvador, BA: EDUFBA, 2008, p.278.

CORACINI, Maria José. A celebração do outro: arquivo, memória e identidade: línguas (materna e estrangeira), plurilinguismo e tradução. Campinas. SP: Mercado de Letras, 2007.

CORACINI, Maria José. Transdisciplinaridade e análise do discurso: migrantes em situação de rua. Cadernos de Linguagem e Sociedade. Vol. 11, n. 1, 2010.

DIJK, Teun A. Van. Discurso e poder. 2 ed. São Paulo: Contexto, 2012.

SCHWARCZ, Lilia Moritz. Racismo no Brasil. São Paulo: Publifolha, 2001

ENTREVISTA 01 [jan. 2017]. Entrevistador: Maurício José dos Santos Silva. Dourados-MS, 2010. Arquivo.mp3 (16 min.). Concedida durante curso de Magistério indígena Ara Vera.

ENTREVISTA 02 [jan. 2017]. Entrevistador: Mauício José dos Santos Silva. Dourados-MS, 2010. Arquivos.mp3 (33 min. + 12 min.). Concedida durante curso de Magistério indígena Ara Vera.

FERREIRA, Ricardo Franklin. Afro-descendente: identidade em construção. 1 ed. Rio de Janeiro: Pallas, 2009.

FOUCAULT, M. A ordem do discurso. Trad. Laura Fraga de Almeida Sampaio. 24 ed. São Paulo: edições Loyola, 2014. 
GERRA, Vânia M. Lescano; ALMEIDA, Willian D. Um olhar Foucaultiano sobre a Lei Maria da Penha: Discurso e desconstrução. In: GERRA, Vânia M. Lescano; NOLASCO, Edgar C. (Orgs.). Michel Foucault: entre o passado e o presente, 30 anos de (des)locamentos. Campinas, Pontes, 2015, p. 185 - 206.

HALL, S. Da diáspora: identidades e mediações culturais. Belo Horizonte: Editora da UFMG, 2003.HALL, Stuart. A identidade cultural na pós-modernidade. Rio de Janeiro: DP\&A, 2006.

MOITA LOPES, Luiz Carlos. Identidades fragmentadas: a construção discursiva de raça, gênero e sexualidade em sala de aula. Campinas: Mercado de Letras, 2002.

NASCIMENTO, A. C.; VIEIRA, C. M. N. A escola indígena Guarani e Kaiowá em Mato Grosso do Sul: experiência emancipatória de educação indígena. In: Simpósio Nacional de História - ANPUH, 26, Anais... São Paulo, 2011. 


\title{
CAPÍTULO 3
}

\section{NÚCLEO DE ATIVIDADES DE ALTAS} HABILIDADESISUPERDOTAÇĀO

\section{(NAAHIS) DE MATOGROSSO DO SUL:} IDENTIFICAÇĀO, PLANEJAMENTO E ATENDIMENTO ${ }^{1}$

\author{
Graziela Cristina Jara ${ }^{2}$ \\ Nádia Biagrella ${ }^{3}$
}

1 Este texto é derivado de uma pesquisa de mestrado, financiada pela Coordenação de Aperfeiçoamento de Pessoal de Nível Superior (CAPES), concluída em 2019, no Programa de Pós-Graduação em Educação - Mestrado e Doutorado da Universidade Católica Dom Bosco..

defendida em 2019,

2 Mestra e Doutoranda em Educação Professora do Programa de Pós-Graduação em Educação - Mestrado e Doutorado da Universidade Católica Dom Bosco. Membro do Conselho Brasileiro para Superdotação (ConBraSD) e Técnica de Atendimento Educacional Especializado/ETAEE da Secretaria Municipal de Campo Grande/SEMED/MS. Pesquiusadora do Grupo de Pesquisas Educacional e Órgão de Gestão e Sistema de Ensino - GEPESE. E-mail: grazijarasantos@gmail.com

3 Doutora e Pós-Doutora em Educação. Professora do Programa de Pós-Graduação em Educação - Mestrado e Doutorado da Universidade Católica Dom Bosco, ligada a linha de pesquisa Política, Gestão e História da Educação. Líder do Grupo de Pesquisa em Políticas Educacionais e Órgãos de Gestão dos Sistemas de Ensino (GEPESE) e da Rede Ibero - Americana de Pesquisa em Política e Gestão da Educação (REIPPGE).E-mail: nadiabiga@hotmail.com 
Resumo: O presente texto tem como objetivo discutir o processo de identificação da Altas Habilidades/Superdotação no contexto escolar, desenvolvido pela equipe do Núcleo de Atividades de Altas Habilidades/Superdotação, como uma política de ação da Secretaria de Estado de Educação de Mato Grosso do Sul/MS, para construir uma educação inclusiva. Para tanto, por meio de uma pesquisa bibliográfica e documental, que compreendeu coleta e análise de dados produzidos em âmbito Federal e estadual, como leis, decretos e resoluções nacionais e estaduais que garantem os direitos à educação dos alunos com Altas Habilidades/Superdotação. Os resultados permitiram constatar que a matricula é condição para o acesso ao ensino, contudo, em relação aos alunos com $\mathrm{AH} / \mathrm{SD}$ são necessários professores especializados para efetivar o atendimento educacional especializado, voltado para a produtividade na escola e desenvolvimento das capacidades de produção acadêmica.

Palavras-chave: Políticas Educacionais; Inclusão; Altas Habilidades/Superdotação.

\section{INTRODUÇÃo}

A inclusão escolar do aluno com Altas Habilidades/Superdotação (AH/SD) e o Atendimento Educacional Especializado (AEE) estão previstos legalmente (BRASIL, 1996, 2001a, 2014). Sob responsabilidade dos órgãos públicos, políticas e projetos foram criados e implantados para oferecer atendimento a esse público. As escolas foram orientadas a realizar adaptações tanto no currículo como nos procedimentos metodológicos e, ainda, oferecer recursos, serviços e suplementação curricular, de acordo com as especificidades encontradas.

Atualmente, esse assunto tem ganhado espaço entre os debates na literatura da Educação Especial, e mesmo com um expressivo aumento do número de atendimentos oferecidos a esse público, ainda existem muitos alunos sem identificação e atendimento adequado.

Compreendendo que é preciso acompanhar e realizar os encaminhamentos necessários para contribuir na formação desses estudantes por meio do enriquecimento curricular, em 2005 o Ministério de Educação (MEC) por intermédio da Secretaria de Educação Especial do Ministério de Educação (SEESP), com o objetivo de apoiar os sistemas de ensino, regulamentou e possibilitou que os Estados da Federação implantassem Núcleos de 
Atividades para identificar e atender os estudantes com Altas Habilidades/Superdotação, e assim foi criado o NAAH/S (BRASIL, 2008; VIRGOLIM, 2007; PÉREZ \& FREITAS, 2009).

O NAAH/S - MS constituiu-se na política de ação da Secretaria de Estado da Educação a partir da proposta do MEC/SEESP, para atender aos estudantes com indicativos de Altas Habilidades/Superdotação, matriculados na rede pública de ensino. Assim, enquanto dever institucional do Estado e, sob a perspectiva da educação especial e inclusiva, o referido núcleo se estabelece como um referencial para o desenvolvimento das práticas, segundo especificado nas legislações que abarcam a Educação Especial (BRASIL, 1994, 2008, 2009, 2011).

Com o objetivo de construir uma educação inclusiva e de qualidade, a atuação do $\mathrm{NAAH} / \mathrm{S}$ se dá por meio da avaliação e do atendimento ao estudante, ao professor e a família de maneira articulada e integrada, em vista à compreensão da totalidade do processo de ensino-aprendizagem, seguindo o referencial teórico de Altas Habilidades/Superdotação do pesquisador norte-americano Joseph Renzulli, bem como, os princípios teóricos das Inteligências Múltiplas de Gardner (VIRGOLIM, 2007).

Destaca-se aqui a importância do processo de orientação, bem como a identificação precoce, com estimulo continuo de potencial desses alunos por intermédio dos atendimentos de enriquecimento curricular. Não obstante, precisa-se buscar sempre parcerias com outras instituições educacionais e profissionais que tenham condições de contribuir para a ampliação e potencialização do conhecimento dos alunos atendidos, realizando assim, um trabalho pedagógico com os professores de diferentes áreas, priorizando o reconhecimento, acompanhamento e um atendimento complementar e suplementar eficaz.

Esses alunos contam com um enriquecimento curricular por meio de acesso a conteúdos diversificados, para além do que é proposto em sala de aula regular, possibilitando recursos instigadores e criativos.

Podemos citar, dentre as características do estudante com superdotação e/ou altas habilidades, dentre outras: processamento rápido de informação, aprender rapidamente, 
originialidade, imaginação fértil, habilidades de destaque, além de estar sempre bem informado acerca de sua área de interesse.

Demonstra também, habilidade superior em sua área de interesse, com excelente vocabulário, pensa de forma incomum para resolver problemas, com senso crítico apurado, independente e persistente.

Embora essas características nos levem a crer num desempenho superior absoluto, destaca-se que essas características não têm relação direta com um excelente desempenho escolar. Sendo comum a esses alunos a presença de dificuldades nas áreas que não possuam interesse, o que não contraria a identificação da superdotação. Sendo imprescindível a correta verificação de suas habilidades e dificuldades para que seja feito um trabalho de auxilio integral.

Consideram-se crianças com Altas Habilidades, segundo definição oficial (BRASIL, 2008), aquelas que apresentam notável desempenho e/ou elevada potencialidade em qualquer dos seguintes aspectos, isolados ou combinados (VIRGOLIM, 2007):

$\checkmark \quad$ Capacidade intelectual superior: envolve rapidez de pensamento, compreensão e memória elevadas, capacidade de pensamento abstrato, curiosidade intelectual, poder excepcional de observação;

$\checkmark \quad$ Aptidão acadêmica específica: envolve atenção, concentração, motivação por disciplinas acadêmicas do seu interesse, capacidade de produção acadêmica, alta pontuação em testes acadêmicas e desempenho excepcional na escola;

$\checkmark \quad$ Pensamento criativo ou produtivo: refere-se à originalidade de pensamento, imaginação, capacidade de resolver problemas de forma diferente e inovadora, capacidade de perceber um tópico de muitas formas diferentes;

$\checkmark \quad$ Capacidade de liderança: refere-se à sensibilidade interpessoal, atitude cooperativa, capacidade de resolver situações sociais complexas, poder de persuasão e de influência no grupo, habilidade de desenvolver uma interação produtiva com os demais; 
$\checkmark \quad$ Talento especial para artes visuais, dramáticas e música: envolve alto desempenho em artes plásticas, musicais, dramáticas, literárias ou cênicas (por exemplo, facilidade para expressar ideias visualmente; sensibilidade ao ritmo musical; facilidade em usar gestos e expressão facial para comunicar sentimentos);

$\checkmark \quad$ Capacidade psicomotora: refere-se ao desempenho superior em esportes e atividades físicas, velocidade, agilidade de movimentos, força, resistência, controle e coordenação motora fina e grossa.

Outro ponto essencial na avaliação é a análise das características de Altas Habilidades/Superdotação. De acordo com Winner (1998), existem algumas características que são mais marcantes no estudante com $\mathrm{AH} / \mathrm{SD}$, tais como: aprende rápido e facilmente sem necessitar de repetições, possui grande curiosidade, faz um número ilimitado de perguntas, tem vocabulário avançado e contextualizado, é crítico consigo e com os outros, tem alto nível de energia e amplitude de interesses, memoriza facilmente e lembra sempre "o prometido", resolve problemas difíceis ou complexos, encontrando soluções originais e inesperadas, não aceita afirmações ou respostas superficiais, demonstra grande persistência e intensa concentração, sente-se desafiado por novas ideias, sensível às injustiças, tanto pessoais como sociais, gosta de defender suas razões e também de bons argumentos, possui talento incomum para expressar-se artisticamente, gosta de conviver com pessoas de nível intelectual e/ou interesses similares, habilidade de gerar ideias, níveis avançados de julgamento moral e motivação intrínseca (WINNER, 1998).

Todo processo de avaliação realizado com os estudantes com indicadores de AH/ SD é pautado na teoria dos Três Anéis de Joseph Renzulli (RENZULLI \& REIS, 1997), que concebe a superdotação como um conjunto de comportamentos que resultam da confluência entre habilidade acima da média, criatividade e envolvimento com a tarefa, identificados dentro da área de interesse do estudante. Os três anéis estão dispostos em um padrão xadrez que representa a interação entre fatores ambientais e de personalidade que favorecem o aparecimento da superdotação.

Renzulli descreve o comportamento superdotado como uma intersecção entre três anéis. Estes anéis abarcam as três características comumente presentes na pessoa com Altas Habilidades/Superdotação: Habilidades Acima da Média, Envolvimento com a Tarefa 
e Criatividade. Esse comportamento ocorre em um contexto representado por ele em um fundo quadriculado. Nesta representação ele pretende demonstrar que essas características ocorrem em um contexto que não pode ser desprezado, e que podem exercer influência direta na manifestação desse comportamento que, segundo ele, ocorre em certos contextos, em certo tempo, em certas pessoas.

Para Renzulli, este fenômeno se dá no espectro do desenvolvimento humano e pode ser entendido por meio dos comportamentos observáveis apresentados pelo indivíduo em uma dada situação, quando o potencial é convertido em desempenho em uma área específica.

Nesse contexto, o Atendimento Educacional Especializado é de extrema importância para o desenvolvimento do potencial do aluno com AH/SD. Como explica o documento orientador aos estados da federação (BRASIL, 2006), o objetivo do NAAH/S constitui-se no desenvolvimento das potencialidades dos alunos com Altas Habilidades/ Superdotação, garantindo a eles um ensino de qualidade. Dessa forma, o programa busca desenvolver as capacidades desse alunado, porém, cabe à sociedade estimular e valorizar os avanços por eles alcançados, os quais podem vir a ser agentes de transformação social.

A fim de alcançar esses objetivos no contexto escolar, os técnicos do núcleo realizam visita in loco às escolas estaduais da capital. Durante essas visitas, são sugeridas às unidades escolares, a possibilidade de realização de formações continuadas para os professores, coordenadores e direção escolar, que visam oferecer subsídios e conhecimentos das características de $\mathrm{AH} / \mathrm{SD}$, esclarecendo aos servidores sobre o processo de avaliação e encaminhamento ao NAAH/S, a fim de facilitar o processo de indicação de alunos para avaliação de AH/SD.

É notável a falta de informação que muitos profissionais da educação têm sobre as características das Altas Habilidades/Superdotação. Assim, as formações continuadas oferecidas pelo núcleo vêm apresentando resultados favoráveis em relação ao crescente número de estudantes que passam a receber o AEE no NAAH/S.

Posteriormente ao processo de indicação para avaliação, cada equipe técnica, composta por uma pedagoga e uma psicóloga, realiza entrevista inicial com os pais e/ou responsáveis do aluno para apresentação da proposta de avaliação e possível atendimento no 
NAAH/S. O atendimento inicia-se com a avaliação do estudante na própria escola, por meio de atividades pedagógicas criativas, jogos e teste psicopedagógico. Essa avaliação tem caráter qualitativo e processual, e seu tempo de duração varia de acordo com as respostas do estudante ao processo, podendo alcançar de 3 a 6 meses. Confirmada a presença das Altas Habilidades/Superdotação, o estudante é direcionado a participar das atividades do NAAH/S a fim de receber o Enriquecimento Curricular assegurado por lei a este alunado.

Sendo o NAAH/S o órgão responsável pelo atendimento a todos os estudantes das escolas estaduais de MS, as ações referentes aos municípios do interior ocorrem por meio de orientações técnico-pedagógicas aos profissionais e unidades escolares de cada município, e são realizadas pela equipe técnica da capital sempre que solicitado.

\section{IDENTIFICAÇÃo do ALUNO PÚBLICO-ALVO dA EDUCAÇÃo ESPECIAL}

A Educação é direito de todos e dever do Estado (BRASIL, 1998), para tanto, é necessário que todos os estudantes, sejam eles identificados ou não com $\mathrm{AH} / \mathrm{SD}$, recebam uma educação de qualidade que atenda suas necessidades educacionais. Quando se trata de Educação Especial, essas necessidades educacionais são ainda mais específicas, e o Estado deve dispor de serviços e recursos pedagógicos que devem ser prestados de maneira suplementar à educação desses estudantes com Altas Habilidades/Superdotação (BRASIL, 2014a), para que dessa forma possam "desenvolver mais amplamente o seu potencial e/ou superar ou minimizar suas dificuldades" (BRASIL, 1994).

Essa necessidade foi reconhecida e traçada como meta no Plano Nacional de Educação (BRASIL, 2014b), assim, o Estado se compromete a oferecer o Atendimento Educacional Especializado para o público-alvo da Educação Especial (BRASIL, 2011a).

Oferecer atendimento educacional que atenda às especificidades de todos os alunos, só é possível quando se tem conhecimento sobre suas características, limitações, potencialidades, serviços e recursos disponíveis. Assim, enfrentar as barreiras e buscar soluções para as dificuldades encontradas durante a realização das práticas pedagógicas se tornará 
possível partindo da identificação das necessidades educacionais especiais dos alunos.

Desta forma, a Resolução CNE/CEB n ${ }^{0}$, de 11 de setembro de 2001, afirma que:

Art. $5^{\circ}$ Consideram-se educandos com necessidades educacionais especiais os que, durante o processo educacional, apresentarem: [...]

III - altas habilidades/superdotação, grande facilidade de aprendizagem que os leve a dominar rapidamente conceitos, procedimentos e atitudes. (BRASIL, 2001b, p.2)

A atualização desta Resolução CNE/CEB, de n 04 , de 2 de outubro de 2009, atualiza as discussões com mais especificações, afirmando que:

Art. $4^{\circ}[\ldots]$ considera-se público-alvo do AEE: [...]

III - Alunos com altas habilidades/superdotação: aqueles que apresentam um potencial elevado e grande envolvimento com as áreas do conhecimento humano, isoladas ou combinadas: intelectual, liderança, psicomotora, artes e criatividade. (BRASIL, 2009, p.1)

Para tanto, em primeira instância, a identificação desses alunos no cotidiano escolar geralmente é feita por meio do olhar do professor, que deve estar atento a quaisquer facilidades e interesses acima da média que o aluno apresente. Segundo Lupinacci $(2015$, p.43) "o professor é o principal agente educacional nas escolas, é este profissional que vivencia todas as dificuldades cotidianas, trabalha diariamente pela aprendizagem e desenvolvimento de seus alunos", ele também é responsável pela construção dos valores - nos quais as diferenças individuais são respeitadas - e do ambiente colaborativo em que um apóia o outro. Mazzotta (1993) confirma essa ideia afirmando que:

O professor é "pilar fundamental" no conjunto de elementos que caracteriza a educação especial. Sua Competência "põe em xeque" a estrutura e o funcionamento da educação escolar. Necessariamente mediadas pela educação comum à educação especial e a situação de excepcionalidade na educação escolar dependem fundamentalmente da qualidade ou da competência dos professores comuns e especializados. (MAZZOTTA, 1993, p. 257)

É através da postura desse profissional frente às diferenças em sala de aula que oportunizam conhecer o aluno, suas limitações e/ou progressos, possibilitando assim, sua real inclusão. A partir do olhar nas especificidades dos alunos, a inclusão deixa de ser concebida apenas como o ingresso na rede regular de ensino, pois uma postura

ética, em sua dimensão crítica e transformadora, é que referenda a luta pela 
inclusão escolar. O convívio com as diferenças e a aprendizagem como experiências relacional, participativa, que produz sentido para o aluno é uma ação de inclusão, pois contempla sua subjetividade (MANTOAN, 2003, p.31).

Então, é a partir da observação das especificidades dos alunos na realidade escolar que identificamos a necessidade de oferecer atendimento educacional especializado, com um currículo específico e eficaz para a aquisição da aprendizagem significativa, capaz de contribuir efetivamente na aprendizagem e desenvolvimento das competências dos referidos alunos.

\section{TRAÇANDO O PERFIL DOS ALUNOS COM ALTAS HABILIDADES/SUPERDOTAÇÃo}

Identificar a especificidade de um aluno requer um diálogo e uma parceria entre família e escola. Ambos devem estar cientes dos acontecimentos e eventualidades apresentadas pelo sujeito no âmbito escolar e social. Desta forma,

[...] se professores e orientadores perceberem que uma criança apresenta indicadores de altas habilidades, podem consultar colegas, ou a família do aluno, [...] o mesmo pode acontecer em sentido inverso: se a família de um aluno considerar que ele apresenta necessidades educativas especiais em virtude de algum talento ou habilidade, pode também solicitar atenção especial dos profissionais da escola (CUPERTINO, 2008, p.38).

$\mathrm{O}$ atendimento especial educacional diferenciado destinado aos alunos com $\mathrm{AH} / \mathrm{SD}$ está previsto em lei desde 1971, no Artigo $9^{\circ}$ da Lei 5.692, de 11 de agosto que prevê que "os superdotados deverão receber tratamento especial, de acordo com as normas fixadas pelos competentes Conselhos de Educação" (BRASIL, 1971, s. p.).

De acordo com Galbraith e Delisle (1996 apud VIRGOLIM, 2007) para um levantamento inicial de características da superdotação do aluno no contexto escolar, é necessário a atenção do professor à lista de comportamentos elencadas a seguir.

Aprende fácil e rapidamente; Original, imaginativo, criativo, não-convencional; Amplamente informado, informado em áreas não comuns; Pensa de forma incomum para resolver problemas; Persistente, independente, auto-direcionado (faz coisa sem que seja mandado); Persuasivo, capaz de influenciar os outros; Mostra senso comum, pode não tolerar tolice; Inquisitivo, cético, curioso sobre o como 
e porque das coisas; Adapta-se a uma variedade de situações e novos ambientes; Esperto ao fazer coisas com materiais comuns; Habilidades nas artes (música, dança, desenho etc.); Entende a importância da natureza (tempo, lua, sol, estrelas, solo, etc.); Vocabulário excepcional, verbalmente fluente; Aprende facilmente novas línguas; Trabalhador independente, mostra iniciativa; Bom julgamento lógico; Flexível, aberto; Versátil, muitos interesses além da idade cronológica; Mostra insights e percepções incomuns; Demonstra alto nível de sensibilidade, empatia com relação aos outros; Apresenta excelente senso de humor; Resiste à rotina e repetição; Expressa idéias e reações, frequentemente de forma argumentativa; Sensível a verdade e à honra. (VIRGOLIM, 2007, p. 44).

É comum perceber que o professor, somente com a formação inicial docente adquirida na graduação, não encontra subsídios suficientes para realizar uma identificação precisa e um atendimento educacional especializado com qualidade aos alunos da Educação Especial. É necessário que ele esteja em constante formação, possibilitando a si mesmo contínuas reflexões sobre sua prática, atualizando seus conhecimentos às constantes mudanças de paradigmas da sociedade e proporcionando-lhe uma maior competência profissional.

Segundo Pletsch (2009, p.148) “a falta de preparo e informação impede o professor de desenvolver uma prática pedagógica sensível às necessidades do aluno especial incluído". Com conhecimentos teóricos capazes de identificar os diversos comportamentos apresentados pelos alunos com $\mathrm{AH} / \mathrm{SD}$, o professor conseguirá atender as necessidades educacionais especiais de seus alunos, atingindo a finalidade da educação que é o pleno desenvolvimento do educando, seu preparo para o exercício da cidadania e sua qualificação para o trabalho, de forma prazerosa, gratificante e interessante (BRASIL, 1996).

Devido ao elevado nível de desenvolvimento intelectual do aluno com $\mathrm{AH} / \mathrm{SD}$, muitas vezes o currículo empregado não lhe desperta o interesse no cotidiano de sala de aula. Pérez (2007), explica que algumas vezes o professor tem dificuldade de reconhecer esse desinteresse, ou quando reconhece, diagnostica essa atitude como mau comportamento e não como a falta de uma atividade que estimule o aluno em sua capacidade intelectual superior.

Comunidade escolar e familiares devem dialogar para juntos buscarem condições de desenvolver as potencialidades e identificar o nível de superdotação deste aluno. A escola deve influenciar os alunos a desenvolver os seus talentos no dia a dia de sala de 
aula, assim a expressão de suas potencialidades será constante e facilitará a identificação de suas habilidades (VIRGOLIM, 2014). O NAAH/S fornece subsídios pedagógicos para que isso aconteça por meio de palestras e orientações sobre o tema, como forma de favorecer o desenvolvimento dos potenciais destes estudantes, em especial nas áreas em que já apresentem um alto desempenho.

Quanto à família, é importante que tenha a devida orientação, suporte teórico e emocional, com vistas a melhor compreensão do comportamento e demandas de seus filhos, o que pode favorecer as relações interpessoais e incentivar o desenvolvimento global da criança. O Núcleo de Atividades de Altas Habilidades/Superdotação (NAAH/S) tem como seus principais pilares a "orientação às famílias e a formação continuada dos professores, constituindo a organização da política de educação inclusiva de forma a garantir atendimento aos estudantes da rede pública de ensino" (BRASIL, 2008, p. 5).

\section{CONSIDERAÇÕES FINAIS}

Após o exposto pode-se inferir que a identificação do perfil do Altas Habilidades/ Superdotação é o ponto de partida para o acompanhamento e desenvolvimento eficaz de suas potencialidades necessidades individualizadas, buscando formas alternativas de estímulos coerentes com seu nível intelectual e de acordo com suas preferências e interesses.

Todavia, o primeiro passo é viabilizar o acesso ao ensino, o que não basta por si só, uma vez que os alunos com AH/SD precisam de professores especializados para as salas de aulas regulares e para o atendimento educacional em salas de recursos; de programas de enriquecimento/aprofundamento dos conhecimentos, para evitar essa desmotivação.

O trabalho conjunto entre família, escola e os centros de atendimento educacional especializado e toda comunidade escolar, é outro passo importante para que a inclusão aconteça de forma no convívio com as diferenças, de forma participativa e inclusiva, fazendo com que o aluno desenvolva um sentimento de pertença com a comunidade escolar.

O NAAH/S - MS constituiu-se na política de ação da Secretaria de Estado da Educação, como objetivo de promover ações na perspectiva da educação especial e inclusiva, que envolvem ações políticas, sociais, culturais e pedagógicas em defesa do direito de 
todos à educação, fundamentado na concepção de direitos humanos, que tem como fundamento direitos iguais e inalienáveis para todos, liberdade, justiça e da paz no mundo.

\section{REFERÊNCIAS}

BRASIL. Ministério da Educação. LEI No 5.692, de 11 de agosto de 1971. Fixa Diretrizes e Bases para o ensino de $1^{\circ}$ e $2^{\circ}$ graus, e dá outras providências. Brasília, DF: MEC, 1971. Não paginado. Disponível em: < http://www2.camara.leg.br/legin/fed/lei/1970-1979/lei-5692-11-agosto-1971-357752-publicacaooriginal-1-pl.html>. Acesso em: 04 ago. 2017

. Constituição Federal de 1988. Constituição da República Federativa do Brasil de 1988. Brsília, DF: Senado, 5 out. 1988. Não paginado. Disponível em: <http://www. planalto.gov.br/ccivil_03/constituicao/ConstituicaoCompilado.htm> Acesso em: 04 ago. 2017.

. Ministério da Educação e do Desporto. Secretaria de Educação à Distância. Política Nacional de Educação Especial. Brasília: MEC/SEESP, 1994.

. Ministério da Educação. Lei no 9.394, de 20 de dezembro de 1996. Lei de Diretrizes e Bases da Educação Nacional. Brasília, DF: MEC, 1996. Não paginado. Disponível em: <http://www.planalto.gov.br/ccivil_03/leis/19394.htm> Acesso em: 20 jul. 2017

. Ministério da Educação. Lei ${ }^{\circ} 10.172$, de 9 de janeiro de 2001. Plano Nacional de Educação. Brasília, DF: MEC, 9 jan. 2001a. Não paginado. Disponível em: <http:// www.planalto.gov.br/ccivil_03/leis/leis_2001/110172.htm>. Acesso em: 04 ago. 2017

. Ministério da Educação. Resolução CNE/CEB no 02, de 11 de setembro de 2001, Institui Diretrizes Nacionais para a Educação Especial na Educação Básica. Brasília, DF: MEC, 11 set. 2001b. 5 p. Disponível em: < http://portal.mec.gov.br/cne/arquivos/pdf/ CEB0201.pdf>. Acesso em: 04 ago. 2017

. Ministério da Educação. Secretaria de Educação. Núcleo de Atividades de Altas Habilidades/Superdotação. Documento Orientador - Execução da Ação. Brasília, DF: MEC/SEESP, 2006. 64 p. Disponível em: < http://portal.mec.gov.br/seesp/arquivos/doc/ documento\%20orientador_naahs_29_05_06.doc>. Acesso em: 03 ago. 2017

. Ministério da Educação. Secretaria de Educação Especial. Política Nacional de Educação Especial na Perspectiva da Educação Inclusiva. Brasília, DF: MEC/SEESP, 7 jan. 2008. 19 p. 
. Ministério da Educação. Conselho Nacional de Educação Câmara de Educação Básica Resolução $n^{\circ}$ 4, de 2 de outubro de 2009. Institui Diretrizes Operacionais para o Atendimento Educacional Especializado na Educação Básica, modalidade Educação Especial. Brasília, DF: MEC. 5 de outubro de 2009. 3 p. Disponível em: $<$ http://portal.mec. gov.br/dmdocuments/rceb004_09.pdf>. Acesso em: 03 ago. 2017

. Ministério da Educação. Decreto ${ }^{0} \mathbf{7 . 6 1 1}$, de 17 de novembro de 2011. Dispõe sobre a educação especial, o atendimento educacional especializado e dá outras providências. Brasília, DF: MEC, 2011b. Não paginado. Disponível em: $<$ http://www.planalto.gov.br/ccivil_03/_Ato2011-2014/2011/Decreto/D7611.htm\#art11> Acesso em: 04 ago 2017

. Ministério da Educação. Secretaria de Educação Continuada, Alfabetização, Diversidade e Inclusão. Diretoria de Políticas de Educação Especial. Nota Técnica N 04 de 23 de janeiro de 2014. Orientação quanto a documentos comprobatórios de alunos com deficiência, transtornos globais do desenvolvimento e altas habilidades/superdotação no Censo Escolar. Brasília, DF: MEC / SECADI / DPEE, 23 jan. 2014a. 4 p.

. Câmara dos Deputados. Plano Nacional de Educação 2014-2024. Lei $n^{\circ} 13.005$, de 25 de junho de 2014, que aprova o Plano Nacional de Educação (PNE) e dá outras providências. Brasília, DF: Cedi/Coedi, 25 jun. 2014b. 86p.

CUPERTINO, C. M. B. (Org). Um olhar para as altas habilidades: construindo caminhos. Secretaria da Educação, CENP/CAPE. São Paulo: FDE, 2008. Disponível em: < www. christinacupertino.com.br/arquivos/Altas_habilidades.pdf >. Acesso em: 04 ago. 2017.

GALBRAITH, J.; DELISLE, J. The gifted kid's survival guide: A teen handbook. Minneapolis, MN: Free Spirit Publishing, 1996. In: VIRGOLIM, A. M. R. Altas Habilidades/Superdotação: Encorajando Potenciais. Ministério da Educação. Brasília, DF: MEC, SEESP, 2007. 70 p. Ilustrações coloridas.

LUPINACCI, L. G. R. O olhar do professor para a inclusão escolar - possíveis aproximações entre educação e psicanálise. Universidade de São Paulo, 2015.

MANTOAN. M. T. E. Inclusão escolar. O que é? Por quê? Como fazer?. São Paulo: Moderna, 2003.

MAZZOTTA, M. J. S. Trabalho docente e formação de professores de educação especial. São Paulo: EPU, 1993. 
PÉREZ, S. P. B. Inclusão para superdotados. Ciência Hoje, São Paulo, v. 41, n. 245, p. 8-11, jan./fev. 2007. Disponível em: < http://cienciahoje.uol.com.br/revista-ch/revista-ch-2008/245> Acesso em: 10 nov. 2014

PÉREZ, S. G. P. B. \& FREITAS, S. N. Estado do conhecimento na área de altas habilidades/superdotação no Brasil: uma análise das últimas décadas. Anais da $32^{\text {a }}$ Reunião da Associação Nacional de Pós-Graduação e Pesquisa em Educação (Anped), Caxambu, 2009. 17 p. Disponível em: <http://32reuniao.anped.org.br/arquivos/trabalhos/GT155514--Int.pdf $>$ Acesso em: 03 ago. 2017

PLETSCH. M. D. A formação de professores para a educação inclusivas: legislação, diretrizes políticas e resultados de pesquisa. Educar, Curitiba, n.33, Editora UFPR, 2009.

RENZULLI, J. S.; REIS, S. M. The Schoolwide Enrichment Model: A how-guide for educational excellence (2nded). Mansfield Center, CT: Creative Learning Press. 1997. In: VIRGOLIM, A. M. R. Altas Habilidades/Superdotação: Encorajando Potenciais. Ministério da Educação. Brasília, DF: MEC, SEESP, 2007. 70 p. Ilustrações coloridas.

VIRGOLIM, A. M. R. Altas Habilidades/Superdotação: Encorajando Potenciais. Ministério da Educação. Brasília, DF: MEC, SEESP, 2007. 70 p. Ilustrações coloridas.

VIRGOLIM, A. M. R. A contribuição dos instrumentos de investigação de Joseph Renzulli para a identificação de estudantes com altas habilidades/superdotação. Revista Educação Especial, v.27, n.50, 2014.

WINNER, E. Crianças superdotadas: mitos e realidades. Porto Alegre: Artes Médicas, 1998. 


\title{
CAPÍTULO 4
}

\section{ATENDIMENTOEDUCACIONAL}

\section{ESPECIALIZADO PARA ESTUDANTES}

COMCARACTERÍSTICAS

DE PRECOCIDADE'

\section{SPECIALIZED EDUCATIONAL SERVICE FOR STUDENTS WITH PRECOCITY CHARACTERISTICS}

\author{
Priscilla Basmage Lemos Drulis ${ }^{2}$
}

1 Artigo advindo de dois resumos expandidos apresentados no I Webinário sobre Formação de Professores - "Os desafios de ensinar e aprender" ESALQ/USP, na modalidade online, 2020.

2 Mestre em Educação; Universidade Estadual de Mato Grosso do Sul - UEMS; Campo Grande, Mato Grosso do Sul, Brasil; pribasmage@hotmail.com.; http://orcid.org/0000-0003-0622-2504 
Resumo: Este artigo decorre de um relato de experiência sobre o atendimento educacional especializado para precoces com indicativos de Altas habilidades/Superdotação, ofertado pelo Centro Estadual de Atendimento Multidisciplinar para Altas Habilidades/Superdotação (CEAM/ AHS), situado em Campo Grande - MS, que tem como desígnio identificar e promover o atendimento, bem como efetivar a avaliação formal para Altas Habilidades/Superdotação. Diante desse atendimento educacional especializado tem como princípio filosófico a educação inclusiva, uma vez que esse público alvo pertence à Educação Especial, além de promover o desenvolvimento das potencialidades desses estudantes, ainda há um olhar mais atento e cuidadoso, pois, há o reconhecimento que o precoce é uma criança que tem suas particularidades e suas precisões advindas da infância.

Palavras-chaves: Altas Habilidades/Superdotação; Educação Especial; Inclusão.

\begin{abstract}
This article stems from an experience report on specialized educational care for precocious children with indications of High Abilities/Giftness, offered by the State Center for Multidisciplinary Care for High Abilities/Giftness (CEAM/AHS), located in Campo Grande - MS, which has with the purpose of identifying and promoting the service, as well as carrying out the formal assessment for High Abilities/Giftness. In view of this specialized educational service, inclusive education is the philosophical principle, since this target audience belongs to Special Education, in addition to promoting the development of the potential of these students, there is still a more attentive and careful look as there is recognition that the precocious is a child that has its particularities and its precisions arising from childhood.
\end{abstract}

Keywords: High Abilities/Giftness; Special education; Inclusion.

\title{
INTRODUÇÃo
}

No mundo contemporâneo o atendimento ao aluno com Altas Habilidades/Superdotação (AH/SD), constitui uma necessidade. Os programas de atendimento especializado, adequados às necessidades educacionais especiais desses alunos, vêm no sentido de suprir as necessidades que esse alunado apresenta. Alunos com AH/SD são alvo de Atendimento Educacional Especializado (AEE) em todas as etapas e modalidades da Educação (BRASIL, 2008).

Pautados na Política Nacional da Educação Especial (2008), regulamentado pelo Decreto $\mathrm{n}^{\mathrm{o}}$ 6.571, de 18 de setembro de 2008, assim como o Decreto 7.611 de 17 de 
novembro de 2011 que dispõe sobre a educação especial e o atendimento educacional especializado (AEE), o Centro Estadual de Atendimento Multidisciplinar para Altas Habilidades/Superdotação (CEAM/AHS), situado em Campo Grande - MS, oferece o Atendimento Educacional Especializado - AEE para os estudantes com Altas Habilidades/ Superdotação (AH/SD), afim de promover e desenvolver as potencialidades dos estudantes, pautado em uma estrutura pedagógica, tendo como basilar os princípios filosóficos da educação inclusiva.

Esse resumo expandido será um relato de experiência, dentro da área temática inclusão e diversidade, em que o tema surgiu por meio da experiência vivida como profissional que atende aos estudantes precoces no Centro Estadual de Atendimento Multidisciplinar para Altas Habilidades/Superdotação (CEAM/AHS). Sendo assim, como é um assunto novo que requer ainda muito estudo, faz-se necessário compartilhar a experiência, aprofundar o conhecimento por meio de estudos e aperfeiçoar na área de atuação.

Esse artigo é uma pesquisa de caráter bibliográfico e documental, tendo como suporte a legislação, e textos de autores como Gardner, Martins, Chacon, Renzulli, Virgolin, entre outros, tendo como base fontes como livros, artigos, e documentos do tema abordado.

O objetivo desse artigo é realizar um estudo sobre o atendimento educacional especializado às crianças precoces com indicadores de comportamentos de $\mathrm{AH} / \mathrm{SD}$ de Campo Grande- MS, situando a partir da legislação nacional e estadual, por meio de relato de experiência prática, almejando contribuir com a melhoria do atendimento educacional especializado qualificado à esses estudantes, além da promoção do conhecimento sobre o tema.

\section{DESCRIÇÃO DA EXPERIÊNCIA}

Antes de entender sobre como se dá o trabalho com os estudantes precoces, temos que situar quem são eles. Para Martins e Chacon a precocidade é entendida como:

Dentre os subgrupos abrangidos pela expressão altas habilidades, destacamos a precocidade, entendida como o desenvolvimento prematuro de uma habilidade, a 
qual pode localizar-se em qualquer área de domínio, como linguagem, matemática, música, arte, entre outras (MARTINS; CHACON, 2016, p.234).

Esse relato de experiência será sobre a atuação do Centro Estadual de Atendimento Multidisciplinar para Altas Habilidades/Superdotação de Mato Grosso do Sul (CEAM/ AHS) criado pelo Decreto 14.786, de 24 de julho de 2017, com o objetivo de identificar, avaliar, acompanhar e, prestar o Atendimento Educacional Especializado (AEE) aos estudantes com Altas Habilidades/Superdotação, da Rede Estadual de Ensino de Mato Grosso do Sul.

Em que o atendimento educacional especializado acontece no contraturno da escola regular, no espaço do CEAM/AHS, localizado na avenida Tiradentes, número 20, bairro Amambaí, na cidade de Campo Grande - MS, com o oferecimento dos atendimentos de: Arte e Criação, Artes visuais, Desenho, Física, Química, Ciências e Biologia, Matemática, Linguagem, Inglês, Música, Canto, Fotografia, Corpo e Movimento, Xadrez e Criatividade Científica.

De acordo com as Diretrizes Operacionais da Educação Especial para o atendimento educacional especializado (AEE) na Educação Básica o "AEE tem como função identificar, elaborar e organizar recursos pedagógicos e de acessibilidade que eliminam as barreiras para a plena participação dos alunos, considerando suas necessidades específicas. Este atendimento contempla e/ou suplementa a formação dos alunos com vistas à autonomia e independência na escola e fora dela". (BRASIL, 2008, p.1). Diante disso, o CEAM/AHS realiza a suplementação escolar no AEE, utilizando alguns instrumentos pedagógicos que possibilitam um melhor desenvolvimento das habilidades do estudante, de acordo com a sua área de interesse, considerando suas preferências, gostos e anseios. Nesse texto nos deteremos somente nos estudantes precoces com características de Altas Habilidades/Superdotação (AH/SD).

As atividades educativas são instrumentos mediadores que estimulam a capacidade de aprendizagem e transformação, favorecendo a exploração das possibilidades e potencialidades de cada aluno. Por meio de brincadeiras, atividades direcionadas e propostas de criação livre trabalhamos o desenvolvimento das habilidades de cada estudante. 
Neste sentido, o uso de diferentes recursos e estratégias pedagógicas suplementa a aprendizagem e visa uma educação qualitativa e social, de forma a promover a inclusão no contexto escolar.

Os objetivos estão voltados para promoção do desenvolvimento das habilidades de cada estudante, mediando o conhecimento para atender as demandas específicas de cada um, estimular o desenvolvimento da aprendizagem; potencializar a criatividade; instigar a curiosidade; compartilhar experiências; trabalhar com construção de projetos de pesquisas e valorizar os registros das pesquisas.

Nos anos de 2018 e 2019 o AEE aos estudantes precoces era regido por uma acolhida afim de estimular a integração e o envolvimento dos alunos, com propostas interessantes e prazerosas, sugerindo a discussão e reflexão sobre algum poema ou representação dos sentimentos ao ouvir determinada música.

Também era trabalhado a roda de conversa para relembrar juntamente com o grupo os combinados com gentileza, que devem ser executadas por todos e para discutir as observações de cada aluno com relação as atividades propostas no dia. Era oportunizado a troca de experiências, para cada um ou dupla expor o andamento do projeto e a importância da etapa que será trabalhada no dia, com o propósito de incentivar a prática de valores tais como: o respeito pelo próximo, a parceria e o cuidado com o outro e seu espaço individual. Todos os encontros eram dispostos com os seguintes momentos: 1-acolhida; 2Pesquisas, 3- Prática; 4- Produção de slides ou escrita no word e 5-entretenimento (saída).

É válido lembrar que a precocidade vai até os 10 anos de idade, após essa idade devese realizar uma avaliação formal para ver se o estudante tem de fato Altas Habilidades/ Superdotação.

Diante desse fato é importante ressaltar que o CEAM/AHS além de oferecer a suplementação escolar por meio do AEE para os precoces, também é realizado avaliação aos precoces afim de observar as características de AH/SD.

No processo avaliativo para identificar as crianças com características de Altas Habilidades/Superdotação utiliza-se como base os três anéis que determinam o comportamento superdotado segundo Renzulli (1997). Esse parâmetro é o mesmo utilizado para os 
estudantes acima de 10 anos. O pesquisador afirma que são três as características perceptíveis na pessoa com AH/SD: habilidade acima da média, criatividade e envolvimento com a tarefa. E essas características são investigadas e observadas durante a avaliação.

Entretanto, o processo avaliativo da criança é diferente da avaliação realizada com $\mathrm{o}$ adolescente em diversos aspectos. O primeiro aspecto em que a avaliação se diferencia é pelo fato de que pode acontecer de que a criança ainda não seja alfabetizada, e dessa forma, toda a avaliação se dá a partir da oralidade, de técnicas lúdicas, com uso de diversas linguagens que não a escrita. $\mathrm{O}$ segundo aspecto em que a avaliação do precoce se diferencia, está no fato de que o adolescente, quando indicado para avaliação, geralmente, já apresenta uma área de interesse definida de maneira que a avaliação pode acontecer de forma específica nesse domínio de conhecimento. Com a criança, a avaliação explora uma diversidade de áreas de conhecimento buscando identificar a área de interesse mais predominante na criança, que muitas vezes ainda não está definida.

Os alunos são avaliados continuamente por meio das atividades de sondagens e do acompanhamento do registro individual sobre seu desenvolvimento na realização das atividades propostas.

De acordo com Virgolin (2007), as atividades avaliativas se configuram em três tipos diferentes e potenciais para investigação, do tipo I, do tipo II e do tipo III.

Atividades do tipo I: é realizada na sala de aula regular voltada para a participação de todos, tentando romper com as barreiras dos alunos com altas habilidades e envolver todos os membros do contexto escolar no processo de avaliação e desenvolvimento da aprendizagem com propostas significativas.

Atividades do tipo II: realizada tanto na sala de aula regular ou no AEE, são atividades que visam desenvolver o senso crítico, resolução de problemas, pensamento criativo, integração entre os estudantes de diferentes idades e série escolar, desenvolver pesquisas, trabalhar com projetos de interesse, potencializar a comunicação escrita, oral e visual.

Atividades do tipo III: realizada para aprofundar determinado tema de interesse dos estudantes, desenvolver produtos autênticos, adquirir habilidades avançadas sobre o conteúdo abordado, desenvolver a auto avaliação, configurando na autonomia para avaliar 
sua própria aprendizagem. Nesta etapa o estudante desenvolve características de aprendiz autônomo, para Virgolin (p. 66, 2007) "ao atingir esta fase, o aluno está pronto para aprender, desenvolver novas ideias e projetos com o mínimo de instrução e orientação".

Nesse processo avaliativo precisamos ter muito cuidado, pois estamos lidando com pessoas e nossas avaliações podem ter impactos negativos ou positivos na vida delas. Para Virgolin (2007, p.34) “torna-se necessária uma cuidadosa avaliação para se observar o que pode causar o desajuste emocional da criança, ao invés de se assumir que a superdotação fatalmente leva ao desajustamento e que nada pode ser feito quanto a isso".

Nesta perspectiva, consideramos o percurso para identificar se os estudantes apresentam níveis significativos para os aspectos de Altas Habilidades/superdotação e de acordo com Virgolin (2007, p.58) "a atitude mais recomendável entre os especialistas é a inclusão de múltiplas formas de avaliação, buscando dados sobre os talentos e capacidades de alunos tanto em testes formais quanto em procedimentos informais e de observação".

Neste percurso para avaliar se os estudantes precoces apresentam as características para Altas Habilidades/Superdotação elaboramos diferentes instrumentos para avaliá-los.

Algumas atividades foram aplicadas nos primeiros contatos com os estudantes para conhecê-los e trabalhar respeitando suas especificidades.

Desenvolvemos também atividades ao ar livre para avaliar a coordenação motora ampla, noções de lateralidade e equilíbrio. Aplicamos a brincadeira de corrida na linha, amarelinha, twister e corrida com obstáculos.

Com base nas teias de interesse e na lista de interesse que os estudantes preencheram, trabalhamos com a aprendizagem baseada em projetos, sendo específico para cada estudante, de acordo com suas habilidades e interesses. Em alguns momentos o trabalho foi coletivo, por meio de agrupamentos por interesse e em outros momentos tivemos o trabalho individual.

Nos momentos de entretenimento trabalhamos com os jogos pedagógicos variados para observar o comportamento dos estudantes voltados para o cumprimento das regras, convívio social, a esperar a vez para jogar, ao respeito com o outro e o senso de justiça. 
Visando a necessidade dos estudantes precoces com o atendimento educacional especializado, no fim de 2019 e início de 2020 mudou a dinâmica de trabalho em que os estudantes precoces eram atendidos em uma sala separada, pois como uma das características de Altas Habilidades/Superdotação do precoce é estar além da faixa etária e gostar de se interagir com pessoas mais velhas, a equipe pedagógica modificou a estrutura do atendimento, incluindo-os nos atendimentos com os alunos mais velhos, dentro da área de interesse. Porém é importante ressaltar que cada aluno deve ser visto e avaliado individualmente, respeitando suas características próprias

\begin{abstract}
Assim, enquanto um deles pode apresentar uma competência elevada em uma grande diversidade de áreas aliada a uma liderança superior, outro pode mostrar-se extraordinariamente competente em apenas uma área, sendo, porém, imaturo emocionalmente; ainda outro poderá ser fisicamente menos desenvolvido, apresentando, contudo, uma habilidade significativamente superior (ALENCAR; FLEITH, 2001, p.67).
\end{abstract}

Sendo assim, cada estudante escolheu em qual ou quais atendimento(s) gostaria de participar, então o mesmo monta seu horário nos dias que vai ao CEAM/AHS e circula nos atendimentos, sanado suas necessidades. Como o professor de área (química, física, matemática...) não tem tanta preparação para trabalhar com os estudantes precoces, uma professora pedagoga os acompanham, fazendo a mediação para garantir um melhor atendimento. Desta forma, seguimos o que Soares, Sarmento e Tomás $(2005$, p. 60) nos falam sobre a necessidade indispensável de: [...] considerar uma multiplicidade de recursos metodológicos, que permitam tornar audíveis as vozes de todas as crianças [...]".

\title{
ANÁLISE E DISCUSSÃO
}

Após a mudança de direcionamento no atendimento educacional especializado dos precoces foi possível observar um aumento no atendimento, pois no ano de 2019 o CEAM/ AHS contava com 9 precoces e 1 atendimento.

Atualmente, o Centro tem matriculados 113 alunos, realizando trezentos e setenta e quatro (374) atendimentos semanais. Dentre eles quinze (15) alunos precoces matriculados e 43 atendimentos. Ressaltando que os estudantes realizam atendimentos nas áreas de conhecimentos específicos. 
Foi possível analisar que houve uma maior interação entre os estudantes precoces com os demais estudantes com $\mathrm{AH} / \mathrm{SD}$, foi mais nítido observar as características dos três anéis de Renzulli (1997), habilidade acima da média, criatividade e envolvimento da tarefa, bem como as inteligências múltiplas (Gardner 1995) nos atendimentos específicos de área, além de uma troca entre os professores que possibilitou um atendimento de mais qualidade para os precoces.

Ainda que a identificação seja importante, tornou-se indispensável o acompanhamento e o atendimento educacional especializado da criança identificada e de sua família. Pois, segundo Gama (2006), não há razão em ter a identificação sem o atendimento especializado. Por mais que o estudante precoce com comportamento de altas habilidades/ superdotação se evidencie entre seus pares, não conseguiria se apropriar de aspectos técnicos sozinho.

Por isso é de extrema importância um olhar do pedagogo atento no atendimento educacional especializado, pois ele é a base que guiará o precoce, bem como sua família, independente de qual for o agente que faça a criança apresentar capacidades elevadas. Nesta mesma vertente, Marques (2013) assinala que:

Da mesma maneira que a Educação Especial atende as necessidades educacionais do aluno identificado como superdotado, esta deve reconhecer e proporcionar ações pedagógicas voltadas à criança que neste período da educação infantil apresenta características acima da média, mesmo que nos anos seguintes esta fase de precocidade se estacione e o aluno se iguale em relação ao desenvolvimento de seus pares (MARQUES, 2013, p. 39).

Dando continuidade na mesma vertente, Guenther (2012) aponta que a precocidade indica que o ritmo de maturação da criança está mais rápido naquela criança, podendo antecipar o processo de desenvolvimento, sobretudo mental, contudo, não deve ser tido como sinal de maior favorecido em inteligência. Pois este fato só pode ser concretizado com dados colhidos, mais tarde, depois de completada a maturação do sistema nervoso central.

Por isso é sempre importante um olhar mais atento a cada peculiaridade da criança, respeitando suas fases, sua infância, seu momento e sua maturação. 


\section{CONSIDERAÇÕES FINAIS}

Devido a poucas pesquisas referente à precocidade, tema novo e em ascensão, foi possível observar que a prática diária do atendimento educacional especializado a esse público alvo acontece na base da tentativa de sempre melhorar, adequando a realidade do local e respeitando a individualidade de cada estudante.

Sendo assim, este relato de experiência veio com o intuito de partilhar conhecimentos, para aperfeiçoar a nossa prática vivida, além de divulgar o tema pouco debatido na formação docente, o que de fato renderia mais debates e pesquisas na área da Educação especial e inclusiva.

\section{REFERÊNCIAS}

ALENCAR, E.M.L.S.; FLEITH, D.S. Superdotados: determinantes, educação e ajustamento. 2.ed. São Paulo: EPU, 2001.

BRASIL. Ministério da Educação. Secretaria de Educação Especial. Política Nacional de Educação Especial na Perspectiva Inclusiva. Brasília: MEC/SEESP, 2008.

. Decreto no 6571 de 17 de setembro de 2008. Brasília: Jus Brasil. 2008b. Disponível em http://www.jusbrasil.com.br. Acesso em: 18 set 2020

Decreto $\mathbf{N}^{0}$ 7.611, DE 17 DE NOVEMBRO DE 2011. Dispõe sobre a educação especial, o atendimento educacional especializado e dá outras providências.

GAMA, M. C. S. S. Educação de superdotados: teoria e prática. São Paulo: EPU, 2006.

GARDNER, H. Inteligências múltiplas: a teoria na prática. Porto Alegre: Artes Médicas, 1995 .

GUENTHER, Z.C. Crianças dotadas e talentosas...Não as deixem esperar mais. Rio de Janeiro, Ed. LTC,2012.

MARQUES, D. M. C. Reconhecimento por meio de indicadores da precocidade do aluno na educação infantil. 2013, 159 f. (Dissertação de Mestrado) - Programa de Pós-graduação em Educação Especial, Universidade Federal de São Carlos, São Carlos, 2013. 
MARTINS, B. A.; CHACON, M. C. M. Alunos precoces no Ensino Fundamental I:quem são essas crianças? Revista Educação Especial Santa Maria -RS. v. 29. n. 54.p. 233246. jan./abr. 2016 Disponível em: < https://periodicos.ufsm.br/educacaoespecial/article/ view/13710/pdf > Acesso em: abr. 2021.

MATO GROSSO DO SUL. Decreto $\mathbf{n}^{\mathbf{0}} \mathbf{1 4 . 7 8 6}$, de 24 de julho de 2017. Cria o Centro Estadual de Atendimento Multidisciplinar para Altas Habilidades/Superdotação (CEAM/ AHS), com sede no Município de Campo Grande. Diário Oficial n. 9.457, Campo Grande, MS, 25 jul. 2017.

RENZULLI, J. S.; REIS, S. M. The Three-ring conception of giftedness. Connecticut:NEAG - Center for Gifted Education and Talent Development, Storrs, 1997.

SOARES, N. F.; SARMENTO, M. J.; TOMÁS, C. Investigação da infância e crianças como investigadoras: metodologias participativas dos mundos sociais das crianças. Nuances: estudos sobre Educação, ano XI, v.12, n.13, p. 49-64, jan /dez. 2005. Disponível em: <http://revista.fct.unesp.br/index.php/Nuances/article/viewFile/1678/1593>. Acesso em: abr. 2021.

Virgolim, A. M. R. Altas habilidade/superdotação: encorajando potenciais. Angela M. R. Virgolim. Brasília: Ministério da Educação, Secretaria de Educação Especial, 2007. 


\title{
CAPÍtULO 5
}

\section{HISTÓRIA E LEGISLAÇĀO: AEDUCAÇĀODE SURDOS}

\author{
Joice Vareiro da Costa Brites ${ }^{1}$
}

1 Graduada em Pedagogia pela Universidade Federal de Mato Grosso do Sul, Especialista em Educação Especial e Inclusiva pela FAMEV, Professora de Apoio Pedagógico Especializado na Rede Municipal de Ensino de Campo Grande - MS, e-mail: joice.vareiro@hotmail.com 
Resumo: O presente texto tem o intuito não só a título informativo, mas também em função de alertar sobre as leis que amparam a educação da criança surda, que por gerações foi negligenciada, e atualmente podemos identificá- las. Na primeira seção do texto, o objetivo é de traçar os pontos históricos e principais sobre a língua de sinais, com objetivo de conhecimento e progresso dessa linguagem ao longo da história. Os momentos históricos estão divididos em três grandes fases, a primeira dela e à revelação cultural, onde os povos surdos não tinham problemas com a educação a maioria dos sujeitos surdos dominava a arte da escrita e há evidência de que antes do congresso do Milão havia muitos escritores surdos, artistas surdos, professores surdos e outros sujeitos surdos bem-sucedidos. O segundo momento foi o isolamento cultural, onde ocorreu uma fase de isolamento da comunidade surda em consequência do congresso de Milão de 1880 que proibiu o acesso da língua de sinais na educação dos surdos, nesta fase as comunidades surdas resistem à imposição da língua oral. A terceira fase acontece nos anos 60 conhecida como o renascimento. Com os vários respaldos legais que foram instituídos ao longo da história, as possibilidades estão postas, devemos então criar metodologias efetivas para garantir esses direitos.

Palavra chave: língua de sinais, história, educação.

\section{INTRODUÇÃo}

Professora de apoio pedagógico especializado e ex integrante do curso de libras do instituto federal de Mato Grosso do Sul, me foram oportunizadas possibilidades de aprendizagem sobre o ensino da libras, como também a aprendizagem dessa segunda língua. A partir daí surgiu o interesse pelo estudo do papel da língua de sinais em ambientes escolares, retratando essa nova modalidade de atuação para profissionais da educação, atuando com estudantes surdos em fase escolarização.

A infância é uma das principais fases da vida do ser humano, pois inicia seu desenvolvimento tanto social como psíquico, além de continuar o físico. A existência histórica e social é o que impulsiona o crescimento e o desenvolvimento da criança na sua infância e lança um referencial existencial que servirá ao longo de sua vida toda. Isso implica considerar a criança um sujeito de direitos, um sujeito em pleno processo de formação (KAILER; PAULA; SALLES FILHO, 2006).

No Brasil, a Constituição Federal de 1988 normativa o direito à educação para todos em quaisquer circunstâncias. Assim, portanto, as escolas devem ter a inclusão de crian- 
ças surdas como também devem proporcionar aprendizagem bilíngue libras/português às crianças matriculadas em instituições públicas e privadas. Trata-se de dar oportunidade da criança se conhecer e se adaptar a sua deficiência inserida no ambiente escolar (BRASIL, 1988).

Portanto a educação da criança surda, tem o amparo legal pela Constituição Federal de 1988, é dever da família, da sociedade e do Estado assegurar o "[...] direito ao brincar como também à saúde, à alimentação, à educação, e à profissionalização" (BRASIL, 1988). Por sua vez, o Estatuto da Criança e do Adolescente - ECA, mais precisamente no artigo 16, inciso IV, normatiza o direito da criança de brincar como também de praticar esportes e de divertir-se (BRASIL, 1990). Este trabalho tem, então, o objetivo de analisar a importância da legislação e história da educação de crianças surdas, destacando os objetivos centrais da história.

\section{História da EdUCAÇÃo da LÍNGUA dE sinAis}

Neste primeiro momento o objetivo é de traçar os pontos históricos e principais sobre a língua de sinais, com objetivo de referenciar seu progresso, mediante seu contexto histórico, enfatizando os marcos legais. Para a autora Strobel (2009,pg 12) este momento histórico está dividido em 3 grandes fases.

1.Revelação cultural: Nesta fase os povos surdos não tinham problemas com a educação. A maioria dos sujeitos surdos dominava a arte da escrita e há evidência de que antes do congresso do Milão havia muitos escritores surdos, artistas surdos, professores surdos e outros sujeitos surdos bem-sucedidos. 2. Isolamento cultural: ocorre uma fase de isolamento da comunidade surda em conseqüência do congresso de Milão de 1880 que proíbe o acesso da língua de sinais na educação dos surdos, nesta fase as comunidades surdas resistem à imposição da língua oral. 3. O despertar cultural: a partir dos anos 60 inicia uma nova fase para o re-nascimento na aceitação da língua de sinais e cultura surda após de muitos anos de opressão ouvintista para com os povos surdos.

Nesta visão, teremos um panorama sobre este tema, assim na visão Greco- Romana a sociedade acreditava que os surdos não eram seres competentes, porque para aquela sociedade uma vez que o indivíduo não conseguia ouvir, eles certamente não teriam a capacidade de falar, e sem a fala não teriam sua própria linguagem, portanto não teria 
uma construção de pensamentos. Nesta convicção Grega trazendo para nossa sociedade contemporânea vemos vários sujeitos que intitulam a pessoa surda, sendo surdo-mudo, justamente por visões construídas historicamente na sociedade. (SILVA, 2006,p.17).

Neste mesmo momento da história os Romanos também partilhavam deste pensamento Grego, uma de suas considerações sobre o surdo é de que eles teriam retardo metal, e, portanto, eram privados dos seus direitos legais, portando precisavam de um curador para realizar negócios (SILVA, 2006,p.17).

Segundo a autora Karin Strobel (2009) na idade média a igreja católica proibia o casamento de surdos e alegavam que alma surda não podia ser imortal por não conseguir falar seus sacramentos, assim podemos analisar que o fato dos surdos não terem uma linguagem oral os sentenciou a uma visão de não humanos, abaixo de qualquer pessoa na sociedade na idade média.

$\mathrm{Na}$ idade média podemos observar algumas mudanças sobre os surdos na Espanha onde o monge Pedro Ponce de Leon (1510-1584) criou a primeira escola para surdos, ele ensinava filhos de famílias nobres, com o objetivo de que eles futuramente pudessem ter seus direitos legais. (SILVA, 2006,p.17).

Neste sentido, segundo Strobel (2009, p.19) sobre a primeira escola para surdos:

inicialmente ensinava latim, grego e italiano, conceitos de física e astronomia aos dois irmãos surdos, Francisco e Pedro Velasco, membros de uma importante família de aristocratas espanhóis; Francisco conquistou o direito de receber a herança como marquês de Berlanger e Pedro se tornou padre com a permissão do Papa. Ponce de Leon usava como metodologia a dactilologia, escrita e oralização. Mais tarde ele criou escola para professores de surdos. Porém ele não publicou nada em sua vida e depois de sua morte o seu método caiu no esquecimento porque a tradição na época era de guardar segredos sobre os métodos de educação de surdos.

Além desses ensinamentos Pedro Ponce de Leon, revelou que os surdos eram capazes de apreender desenvolvendo a fala a escrita e até a filosofia, e que não eram indivíduos incapazes.

Importante ressaltar que a preocupação e motivação dos pais para buscarem o ensinamento de seus filhos surdos era para garantir o direito à herança, uma vez que eram 
capazes de se comunicar. Mas a intenção sempre era de que o surdo tivesse a oralidade e não que desenvolvesse sua própria linguagem.

O monge Pedro Ponce de Leon, serviu de inspiração para o padre espanhol Juan Pablo Bonet (1579-1623) que se apropriou do método de Pedro Ponce de Leon, e no ano de 1620 desenvolveu sua obra intitulada "Reduccion de las letras y arte para enseñar a hablar a los mudos" na qual ele descrevia seu método para educar surdos como o Alfabeto manual e a língua de sinais. O método de Bonet ficou conhecido e virou referência para autores em várias partes da Europa (Porto,2007,p.308).

Um dos marcos para a educação surda o abade Charles Michel de L'Epée (17121789) que desenvolveu o primeiro instituto nacional para surdos em Paris, no ano de 1760. L'Epée foi o primeiro a reconhecer que o surdo tem uma língua, que o surdo não precisa desenvolver uma língua oral, e sim desenvolver seu próprio método de linguagem, com isso a oralização deixa de ser o foco da educação de surdos pela visão de L'Epée (Porto,2007,p.308).

$\mathrm{O}$ autor construiu a teoria dos sinais metódicos onde os surdos pudessem através de uma palavra representar um sinal e que fosse, mas fiel a escrita da língua francesa. Desta forma o surdo tinha uma representatividade melhor da sua linguagem sinalizada.

Na idade contemporânea Thomas H. Gallaudet (1787- 1851) em 1816 viaja para Europa em busca de métodos para educação de surdos, ele realizou um estágio no Istituto nacional de surdos em Paris, e lá conheceu o professor Louis Laurent Marie Clerc (17851869) que o ensinou a língua de sinais francesa como também os sinais metódicos.

Gallaudet convidou Clerc para ir para o Estados Unidos e fundar uma escola destinadas para surdos. A escola fundada foi a Hartford Scholl no ano de 1817, o ensino era uma junção da linguagem que os alunos já usavam no seu cotidiano e os sinais metódicos como também o alfabeto movél. A educação de surdos no EUA prosperou e teve sua primeira universidade destinada para surdos em 1864 criada pelo filho de Thomas H. Gallaudet, Edward Gallaudet, chamada Gallaudet University, universidade que até hoje é a única destinada a pessoas surdas (STROBEL, 2009, pg.23). 
A idade contemporânea até 1880 tem seu foco principal na moralização, sinais de apoio e métodos de apoio, porém está realidade mudou no mesmo ano com o congresso de Milão onde reuniu-se vários professores, apenas um deles surdo, o resultado foi a decisão de que a educação de surdos não seria, mas realizada pela língua de sinais, seria realizada apenas pela oralidade. Foi proibido o uso da língua de sinais nas escolas, neste momento vemos um retrocesso sobre a língua de sinais (STROBEL, 2009, pg.12).

\section{LÍNGUA BRASILEIRA DE SINAIS: DA HISTÓRIA PARA A LEGISLAÇÃO}

No brasil a história da educação brasileira da início através da fundação do INES Instituto Nacional de Educação de Surdos, o instituto foi fundado em 1987 por Dom Pedro II e pelo padre surdo Huet, e funcionava em regime de internato pois recebiam surdos de várias regiões do país, que por este motivo precisavam morar no INES. Além dos sinais que as crianças já utilizavam antes da fundação do INES e que levaram para o instituto, dentro da instituição aprendiam os sinais metódicos e a língua de sinais Francesa, que era origem do então professor Huert.

O instituto foi criado através da verba estabelecida pela lei de $\mathbf{n}^{0} 939$ de 26 de setembro de 1857 exatamente em seu inciso 10.

$\S 10^{\circ}$ Conceder, desde já ao Instituto dos surdos-mudos a subvenção annual de
$5.000 \$ 000$, e mais dez pensões, tambem annuaes, de $500 \$ 000$ cada huma, a favor
de outros tantos surdos-mudos pobres, que nos termos do Regulamento interno
do mesmo Instituto, forem aceitos pelo Director e Commissão aprovados pelo
Governo. (BRASIL, 1857).

Depois que os alunos se formavam eles regressavam para sua região de origem, e por esse motivo, se disseminou pelo país a língua brasileira de sinais que é a Libras. O INES também oportunizou a formação de professores, que além de aprenderem sobre a cultura da língua de sinais, aprendiam a sinalizar e por sua vez também regressavam para região de origem e repassavam o conhecimento.

Já em 1929, fundou se no estado de São Paulo o instituto Santa Terezinha, que diferente do INES, onde só era permitido alunos surdos, no instituto Santa Terezinha só atendiam meninas surdas, mas também utilizavam dos mesmo métodos e regime de internato. 
Após o INES, a cidade do Rio de Janeiro, foi um polo para as produções e avanços da língua brasileira de sinais, na Universidade Federal do Rio de Janeiro nos anos 80 deu início o primeiro grupo de estudos linguísticos da libras, liderado pela professora Lucinda Ferreira Brito a primeira linguista no Brasil a se dedicar ao estudo da língua de sinais. Após a criação INES a cidade do Rio de Janeiro se tornou berço para conhecimento da educação surda, neste sentido no Rio de Janeiro no ano 1987 foi criada a FENEIS - Federação Nacional de Educação e Integração dos Surdos, sendo a primeira entidade a representar a comunidade surda no país.

Em setembro de 1994 aconteceu a marcha "Surdos Venceremos" neste momento da história, a comunidade surda reivindicou, direitos ao reconhecimento da sua língua "libras", ao direito a educação em libras e ressaltaram a necessidade de interpretes de libras em espaços públicos. Estas reivindicações da comunidade surda que começa na década dos anos 90 acabou resultando em modificações na legislação a partir do ano de 2002.

Somente no ano de 2002 o Brasil reconhece a Libras como uma linguagem utilizada por sinais, ou seja, sendo parte da linguagem Brasileira é também o reconhecimento da comunidade surda, isso se deu através da lei $n^{0}$ 10.436/2002 do então presidente Fernando Henrique Cardoso, que promulga.

Art. 1ํ É reconhecida como meio legal de comunicação e expressão a Língua Brasileira de Sinais - Libras e outros recursos de expressão a ela associados. Parágrafo único. Entende-se como Língua Brasileira de Sinais - Libras a forma de comunicação e expressão, em que o sistema lingüístico de natureza visualmotora, com estrutura gramatical própria, constituem um sistema lingüístico de transmissão de idéias e fatos, oriundos de comunidades de pessoas surdas do Brasil. Art. 2º Deve ser garantido, por parte do poder público em geral e empresas concessionárias de serviços públicos, formas institucionalizadas de apoiar o uso e difusão da Língua Brasileira de Sinais - Libras como meio de comunicação objetiva e de utilização corrente das comunidades surdas do Brasil. Art. 3ํAs instituições públicas e empresas concessionárias de serviços públicos de assistência à saúde devem garantir atendimento e tratamento adequado aos portadores de deficiência auditiva, de acordo com as normas legais em vigor.Art. 4ㅇ $\mathrm{O}$ sistema educacional federal e os sistemas educacionais estaduais, municipais e do Distrito Federal devem garantir a inclusão nos cursos de formação de Educação Especial, de Fonoaudiologia e de Magistério, em seus níveis médio e superior, do ensino da Língua Brasileira de Sinais - Libras, como parte integrante dos Parâmetros Curriculares Nacionais - PCNs, conforme legislação vigente.Parágrafo único. A Língua Brasileira de Sinais - Libras não poderá substituir a modalidade escrita da língua portuguesa.Art. 5ํ Esta Lei entra em vigor na data de sua publicação (BRASIL,2002). 
A lei prevê que a libras não pode substituir a língua portuguesa em sua modalidade escrita, portando a comunidade surda e colocada em forma de bilinguismo forçado, porque além da libras eles precisam dominar a língua portuguesa em sua modalidade escrita.

No ano de 2005 foi assinado o decreto 5.626, que regulamenta a lei $\mathrm{n}^{\circ} 10.436 / 2002$ já citada no texto, este decreto garante o direito a acessibilidade da informação através da sua língua libras, e também a difusão da sua língua por meio da educação. Outro ponto que o decreto regulamenta é que na formação de professores se tenha na grade curricular o ensino da libras, além da formação do tradutor - interprete de Libras/Língua portuguesa (BRASI,2002).

Com este decreto, teve se então a fundação do primeiro curso de libras licenciatura EAD (Ensino a Distância) oferecido pela Universidade Federal de Santa Catarina, inicialmente o curso foi ofertado em 9 polos com 500 vagas, espalhados por todo Brasil. Um marco para comunidade surda pois foi a primeira vez que uma grande quantidade surda teve acesso ao ensino superior público do Brasil. Em 2008 foram ofertadas mais 900 vagas com mais 16 polos, sendo oferecidos o curso de libras em licenciatura e bacharelado (GUARINELLO,BERBERIAN,SANTANA, BORTOLOZZI, 2009, p.7).

Em 2010 aconteceu a CONAE - Conferência Nacional de Educação, que teve como objetivo elaborar o plano nacional de educação, foi uma conferência que aconteceu no dia 28 de março a $1^{\circ}$ de abril de 2010 . Neste evento aconteceu alguns retrocessos para comunidade surda, das 11 propostas expostas pela comunidade surda apenas 3 foram aprovadas, o discurso da não aprovação das propostas nesse evento foi de que as escolas de surdos eram segregacionistas, e que, portanto, ia na contra mão da política nacional de educação. (BRASIL, 2010b, p.20).

A política nacional de educação elucidou sobre a inclusão de alunos, porém existiam muitas escolas que não tinham professores preparados para receber estudantes surdos, assim as escolas para surdos eram de suma importância para educação de surdos, já que a escola comum $^{3}$ não estava preparada para receber esses estudantes. Em contra

3 Escola comum faz menção a escola regular que segue a educação comum, com os níveis de ensino e faixas etárias determinadas em diferentes instituições da educação especial voltada ao ensino e aprendizagem de alunos com deficiências e transtornos do desenvolvimento e aprendizado, por exemplo: escola de cegos, surdos ou escolas que atendem pessoas com deficiência intelectual. 
partida, após a CONAE, aconteceu o fechamento da INES uma das principais escolas para surdos, isso causou uma grande revolta para comunidade surda porque além de ser uma escola, tem um grande valor histórico para comunidade surda. (BRASIL, 2010b, p.20).

Em 2011 aconteceu uma grande mobilização nacional, exatamente no dia 26 de setembro que também e comemorado o dia nacional de surdo, foi chamado de setembro azul, o objetivo dessa mobilização era justamente de fincar as lutas e emendas especificas dos surdos no plano nacional de educação em tramitação no congresso nacional. Com essa mobilização a comunidade surda teve conquistas se tratando da vitória na câmara de deputados no dia 28 de maio de 2012 com a inclusão das classes bilíngues, além da escola inclusiva.

As autoras Campello e Rezende (2014, p.89) relatam sobre este momento da comunidade surda.

enfim, estamos construindo a nossa política da verdade: as escolas bilíngues de surdos não são segregadas, não são segregadoras, e nem segregacionistas como tem alardeado tanto o ministério da educação, pelo contrário, são espaços de construção de conhecimento para cumprimento do papel social de tornar os alunos cidadãos verdadeiros, conhecedores e cumprimento dos seus direitos, o que, em síntese, leva à verdadeira inclusão.

\section{ALGUMAS REFLEXÕES}

Nesse sentido, a pesquisa permitiu refletir sobre a língua de sinais e seus entraves até os dias atuas, onde é obrigatória nas escolas. A escola é um espaço em que, em tempos passados, quando existia, nele geralmente não havia muitos recursos. Era um tempo em que incluir a ludicidade na prática pedagógica era apenas uma frágil diretriz, até porque não havia adequadas orientações sobre como aliar brincadeiras e jogos ao ensino, e não se tinha uma definição de espaço adequado para tanto.

Assim, com as experiências iniciais em outros países e com os vários respaldos legais que foram instituídos, as possibilidades estão postas. Devemos então agora discutir sobre a utilização desses espaços hospitalares, tanto como locais tipicamente lúdicos, quanto como ambientes de aprendizagem, com o intuito de aperfeiçoar a equipe docente 
e de proporcionar suporte de superação de doença e de continuidade escolar para crianças internadas.

\section{REFERÊNCIAS}

BOURDIEU, Pierre; PASSERON, Jean-Claude. Les héritiers: le étudiants et la Cultura. Paris: Les Editions de Minuit, 1964.

BRASIL. Constituição (1988). Constituição da República Federativa do Brasil. Brasília, DF: Senado Federal: Centro Gráfico, 1988.

CAMPELLO, Ana Regina and REZENDE, Patrícia Luiza Ferreira. Em defesa da escola bilíngue para surdos: a história de lutas do movimento surdo brasileiro. Educar em Revista. Curitiba. Editora UFPR. 2014.

BRASIL. Ministério da Educação. Conferência Nacional da Educação - CONAE. Avaliação do Plano Nacional de Educação 2001-2008. Brasília, INEP, 2009. 2009d. 3 v., 775 p. Disponível em: Acesso em: 22 jul. 2010.

FERNANDES, Sueli de Fátima. Educação bilíngüe para surdos: identidades, diferenças, contradições e mistérios. Tese de Doutorado em Estudos Linguisticos. Universidade Federal do Paraná, 2003.

DORIZIAT, Ana. O outro da educação: pensando a surdez com base nos temas Identidade/Diferença, Currículo e Inclusão. Petrópolis, RJ: Vozes, 2009.

GUARINELLO, Ana Cristina; BERBERIAN, Ana Paula; SANTANA, Ana Paula de Oliveira, BORTOLOZZI, Kyrlian Bartira; SCHEMBERG, Simone; FIGUEIREDO, Luciana Cabral. Surdez e letramento: pesquisa com surdos universitários de Curitiba e Florianópolis. In: REVISTA BRASILEIRA DE EDUCAÇÃO ESPECIAL. Universidade Estadual Paulista. v. 15. n¹, 2009, p. $99-120$.

LACERDA, Cristina Broglia Feitosa de. A prática fonoaudiológica frente às diferentes concepções de linguagem. Espaço, Rio de Janeiro, nº 10, p. 30-40, dez./1998.

LOPES, Maura Corcini. A natureza educável do surdo: a normalização surda no espaço da escola de surdos. In: THOMA, Adriana da Silva; LOPES, Maura Corcini (Orgs.). A invenção da surdez: cultura, alteridade, identidades e diferenças no campo da educação. Santa Cruz do Sul: EDUNISC, 2004, p. 33-55. 
PERLIN, Gladis Terezinha. O lugar da cultura surda. In: THOMA, Adriana da Silva; LOPES, Maura Corcini (Orgs.) A invenção da surdez: cultura, alteridade, identidades e diferenças no campo da educação. Santa Cruz do Sul: EDUNISC, 2004, p. 74-82.

PERLIN, Gladis Terezinha. O ser e o estar sendo surdos: alteridade, diferença e identidade. Tese de Doutorado em Educação Universidade Federal do Rio Grande do Sul, 2003.

STROBEL, K. História da educação de surdos. Texto-base de curso de Licenciatura de Letras/ Libras, UFSC, Florianópolis, 2009.

MOURA, Maria Cecília de; LODI, Ana Cláudia Balieiro; HARRISON, Kathryn M.P. História e Educação: o Surdo, a Oralidade e o Uso de Sinais. In: LOPES Fo , Otacílio. (ed.) Tratado de Fonoaudiologia. São Paulo: Editora Roca, 1997.

QUADROS, R. (org). Estudos surdos I. Petrópolis: Arara Azul, 2006.

QUADROS, R, PERLIN, G. (orgs.) Estudos surdos II. Petrópolis: Arara Azul, 2007.

QUADROS, R, STUMPF, M. R. (orgs.) Estudos surdos III. Petrópolis: Arara Azul, 2008. 


\title{
CAPÍTULO 6
}

\section{IDENTIFICANDOESTUDANTES}

\section{COM ALTAS}

\section{HABILIDADESISUPERDOTAÇĀO NOENSINO FUNDAMENTALI}

\author{
Priscilla Basmage Lemos Drulis ${ }^{1}$ \\ Marcela Luzio Ferreira Moquiuti ${ }^{2}$
}

1 Mestre em Educação; Universidade Estadual de Mato Grosso do Sul - UEMS; Campo Grande, Mato Grosso do Sul, Brasil; pribasmage@hotmail.com.; http://orcid.org/0000-0003-0622-2504

2 Mestre em Educação; Universidade Estadual de Mato Grosso do Sul - UEMS; Campo Grande, Mato Grosso do Sul, Brasil, marcelahistur@gmail.com; http://orcid.org/0000-0002-4893-238X 
Resumo: O trabalho com Altas Habilidades/Superdotação (AH/SD), em Campo Grande-MS, é realizado pelo Centro Estadual de Atendimento Multidisciplinar para Altas Habilidades/ Superdotação (CEAM/AHS), identificando, avaliando e atendendo este público alvo. O objetivo deste estudo é realizar uma investigação e levantamento de dados quantitativos e qualitativos com os estudantes dos $5^{\circ}$ anos do Ensino Fundamental I das Escolas Estaduais de Campo Grande/MS, com o intuito de identificá-los e selecioná-los para avaliação de $\mathrm{AH} / \mathrm{SD}$, garantindo o direito ao Atendimento Educacional Especializado (AEE). A metodologia é qualitativa margeada por uma pesquisa de campo que foi dividida em três fases. Participaram 1031 estudantes distribuídos em 24 escolas estaduais. Os resultados parciais da primeira fase, apontaram 64 estudantes com indicadores de AH/SD. Além disso, vários desafios, no processo de triagem, foram enfrentados: (a) falta de local adequado para realização da pesquisa, (b) falta de informação da equipe pedagógica da escola frente ao tema de $\mathrm{AH} / \mathrm{SD}$ e (c) mitos em relação às AH/SD.

Palavras-Chave: Superdotado. Instrumentos de avaliação. Educação Especial.

\section{INTRODUÇÃo}

O Centro Estadual de Atendimento Multidisciplinar para Altas Habilidades/Superdotação (CEAM/AHS) foi instituído pelo decreto nº 14.786 , de 24 de julho de 2017, e tem como objetivo identificar, avaliar, acompanhar, prestar o Atendimento Educacional Especializado (AEE) aos estudantes com Altas Habilidades/Superdotação (AH/SD), da Rede Estadual de Ensino, oferecendo enriquecimento curricular nas áreas de Arte e Criação, Arte e Desenho, Música, Ciência da Natureza, Física, Matemática, Linguagem, Prática Pedagógica do Xadrez, Pedagogia, Química, Filosofia e Projetos. Além de promover a formação continuada dos profissionais da educação, oferecer orientação e acompanhamento às famílias e à comunidade escolar. É válido ressaltar que atualmente, neste centro, são atendidos cento e sessenta e cinco estudantes $(n=165)$, oriundos da Rede Estadual de Ensino, entre cinco $(n=5)$ e vinte e dois anos $(n=22)$ de idade.

Este estudo, visando à identificação de estudantes dos $5^{\circ}$ anos com Altas Habilidades/Superdotação (AH/SD), surgiu em decorrência de uma solicitação da Secretaria de Estado de Educação de Mato Grosso do Sul (SED-MS), que estipulou metas para possibilitar o enriquecimento das habilidades e exploração do potencial destes estudantes com AH/SD, justificando a necessidade de identificá-los o mais cedo possível, pois este ano 
escolar refere-se à idade (10 anos) que inicia o processo de maturação de suas potencialidades, dando um salto qualitativo da infância que determina a precocidade. Para Piske (2016):

A identificação precoce das crianças superdotadas é essencial, mas não deveria ter como principal objetivo dizer se a criança "é ou não é" superdotada, pois a superdotação é mais um processo emergente do que um produto. Portanto a avaliação só fará sentido se for possível oferecer uma intervenção psicoeducativa eficaz e adequada, conforme as características e necessidades de cada discente. Neste sentido, a identificação deve ser planejada de acordo com os objetivos inerentes às formas de intervenção previstas e disponíveis pelo sistema educacional. (PISKE 2016, p. 256).

O CEAMS/AHS segue o conceito de Altas Habilidades/Superdotação disposto na Política de Educação Especial na Perspectiva da Educação Inclusiva (BRASIL, 2008) e o processo de identificação, pautado nos estudos da Teoria das Inteligências Múltiplas de Gardner (1994) e na Teoria dos Três Anéis de Renzulli (1986; 2004).

É válido ressaltar que a avaliação do CEAM/AHS contempla uma análise por meio de atividades que visam reforçar a afinidade do estudante com uma ou mais inteligências (lógico-matemática, linguística, espacial, musical, corporal-cinestésica, naturalista, intrapessoal e interpessoal), e o conceito de Altas Habilidades/Superdotação, percebida com a encontro dos três anéis ( habilidade acima da média, comprometimento com a tarefa e criatividade), permite apoiar-se nos indicadores de AH/SD em qualquer uma dessas inteligências.

Tanto Gardner (1994) como Renzulli (2004) consideram a inteligência em uma concepção multidimensional. Nessa perspectiva, por meio da observação de comportamentos dos estudantes em atividades pedagógicas e criativas, a equipe técnica do CEAM/ AHS avalia os estudantes da rede estadual de ensino de Campo Grande. Sendo assim, a avaliação é pautada em investigar as potencialidades, por meio de um processo contínuo, flexível e coerente com a sua realidade, considerando os aspectos como o contexto social, motivação intrínseca e o comportamento do estudante. Para Gonçalves e Fleith (2016):

[...] vale lembrar que o processo de identificação: faz sentido apenas se acompanhado de um plano educacional ou a um atendimento ou serviço; seja contínuo no sentido de ajudar os alunos a conhecerem e entenderem o seu potencial; seja flexível uma vez que não existe um perfil único de aluno superdotado; seja ba- 
seado em uma concepção de superdotação validade cientificamente; avalie características dos indivíduos à luz dos contextos escolar, familiar, social, cultural e histórico no qual o aluno está inserido (GONÇALVES; FLEITH, 2016, p. 285).

Com esse olhar qualitativo e processual, a equipe técnica do CEAM/AHS realiza a identificação, oferecendo apoio pedagógico aos estudantes e orientações à família, professores e comunidade de uma maneira geral, enquanto os professores do AEE promovem o atendimento educacional especializado de enriquecimento curricular partindo da área de interesse do estudante, com o objetivo de potencializar o desenvolvimento de suas habilidades.

Diante do exposto, parte-se da seguinte questão de pesquisa: quais os desafios que surgem no processo de identificação de estudantes com AH/SD em escolas da rede Estadual de Educação do Mato Grosso do Sul? Sabe-se que a identificação é fundamental para o desenvolvimento das potencialidades desses estudantes, pois, como afirma Chacón (2016, p. 235), "é preciso que tais educandos sejam reconhecidos e incentivados a explorar seus interesses, desenvolvendo ao máximo suas habilidades".

\section{OBJETIVO GERAL}

Realizar uma investigação e levantamento de dados quantitativos e qualitativos com os estudantes dos $5^{\circ}$ anos do Ensino Fundamental I das Escolas Estaduais de Campo Grande/MS, com o intuito de identificá-los com indicadores de Altas Habilidades/Superdotação e selecioná-los para avaliação de $\mathrm{AH} / \mathrm{SD}$, garantindo o direito ao Atendimento Educacional Especializado (AEE).

\section{OBJETIVOS ESPECÍFICOS}

a) Identificar os desafios que surgem no processo de identificação de estudantes com AH/SD em escolas da rede Estadual de Educação do Mato Grosso do Sul;

b) Orientar os professores regentes dos $5^{\circ}$ anos sobre o desenvolvimento do Projeto.

c) Capacitar os professores a respeito dos procedimentos para aplicação dos instrumentos de sondagem aos estudantes com indicadores de AH/SD. 
d) Avaliar e identificar os estudantes com indicadores de Altas Habilidades/Superdotação nos $5^{\circ}$ anos do Ensino Fundamental I da Rede Estadual de Ensino.

\section{MÉTODO}

Adota-se, em todas as fases deste estudo, a pesquisa de campo, por meio de uma abordagem metodológica qualitativa, que, segundo Godoy (2005), visa à descrição, compreensão e interpretação do fenômeno em estudo, o qual foi dividido em três fases (triagem, avaliação, identificação).

\section{LOCAL E PARTICIPANTES}

A pesquisa está sendo realizada em vinte e quatro $(n=24)$ escolas estaduais de Campo Grande - MS, que oferecem $5^{\circ}$ anos e estão participando 1031 estudantes.

\section{PROCEDIMENTOS E INSTRUMENTOS DE COLETA DE DADOS DA PRIMEIRA FASE}

A equipe técnico-pedagógica do CEAM/AHS utilizou os instrumentos de "Autonomeação e Nomeação pelo Colega", elaborados por Renzulli e Reis (1997). Após a aplicação dos instrumentos, foi entregue aos professores pela equipe técnica pedagógica do CEAM/AHS o instrumento: "Lista de Verificação de Indicadores de Altas Habilidades/ Superdotação (LIVIAH/SD)" de Pérez e Freitas (2016). Além desses, foram utilizados instrumentos elaborados pela Equipe Técnica Pedagógica do CEAM/AHS: "Ficha de Observação de Estudantes com Indicativos de Altas Habilidades/Superdotação em Sala de Aula".

\section{PROCEDIMENTOS DE ANÁLISE DE DADOS}

Os dados foram analisados por meio de tabulação, gerando gráficos com os quantitativos de estudantes selecionados, dos quais foram considerados os critérios estabelecidos por Pérez e Freitas (2016), segundo o qual o nome do estudante deve aparecer 51\% em relação ao total da turma do referente ano escolar. Além desse critério de identificação, 
a equipe técnico-pedagógica também está se baseando na análise dos comportamentos dos estudantes, buscando interpretar hábitos, atitudes, tendências de comportamento etc. (MARCONI; LAKATOS, 2011).

\section{RESULTADOS PARCIAIS E DISCUSSÕES}

Nesta primeira etapa do estudo, a identificação teve início com a sondagem nas vinte e quatro Escolas Estaduais de Campo Grande-MS, que oferecem $5^{\circ}$ anos, por meio de formação à coordenação, direção e professores responsáveis. Os professores utilizaram o instrumento elaborado pela equipe técnica pedagógica do CEAM/AHS: Lista de Verificação de Indicadores de Altas Habilidades/ Superdotação (LIVIAH/SD de Pérez e Freitas (2016), para tabular e selecionar os estudantes com indicadores de AH/SD.

A equipe técnica de avaliação aplicou os instrumentos denominados "Autonomeação" e "Nomeação pelo Colega", elaborados por Renzulli e Reis (1997), os quais, conforme Pérez e Freitas (2016) expõem:

Permite (sic) observar o potencial presente nas áreas de maior destaque, algumas características gerais das AH/SD (senso de humor, liderança e cooperação com os demais) e indicadores básicos de criatividade e comprometimento com a tarefa entre as crianças de uma mesma turma, mediante pergunta simples que são respondidas por elas mesmas e por seus colegas. (PEREZ e FREITAS, 2016, p. 41)

Dos 1.031 estudantes avaliados na primeira etapa, referentes às escolas $(n=24)$ da rede estadual de ensino, após a análise dos dados quantitativos e qualitativos, foram identificados 64 estudantes com indicadores de superdotação. Foi alcançado o resultado que equivale a aproximadamente $5 \%$ do total de estudantes que participaram dessa seleção, com base em Renzulli (1986), tendo como referência as estimativas de 3 a 15\% da população com indicadores de AH/SD.

Os estudantes selecionados, nesta primeira fase, farão parte da segunda fase da pesquisa, que é composta pela avaliação de teste psicométrico e pela observação de comportamentos em atividades pedagógicas e criativas. Como reforça Pérez (2013):

A identificação de alunos com Altas Habilidades/Superdotação (AH/SD) nas escolas brasileiras é uma prática crescente e necessária, fundamentalmente a partir da aprovação da nova Política de Educação Especial na Perspectiva da Educação 
Inclusiva (Brasil, 2008a); do Decreto n. 6.571/08(Brasil, 2008b), que determina a adjudicação de matrícula adicional para os alunos atendidos por essa modalidade. (PÉREZ, 2013. p. 58).

Apesar de encontramos vários desafios, no processo de triagem, seleção e identificação, como falta de local adequado para realização da pesquisa, falta de informação da equipe pedagógica da escola frente ao tema de AH/SD e mitos sobre as AH/SD diante da desinformação, conseguimos realizar a contento o objetivo inicial, investigando e levantando dados quantitativos e qualitativos com os estudantes dos $5^{\circ}$ anos do Ensino Fundamental I das Escolas Estaduais de Campo Grande/MS, identificando os que apresentaram indicadores de Altas Habilidades/Superdotação e selecionando-os para avaliação de AH/ SD (segunda fase deste estudo).

A realização da identificação ainda nos primeiros anos escolares, neste caso nos $5^{\circ}$ anos, permite possibilitar que todos os estudantes participem do processo, aumentando as chances de encontrar indicativos de AH/SD, superando, assim, a invisibilidade desses estudantes no contexto escolar. De acordo com Lima e Moreira (2018):

A identificação de Altas Habilidades/Superdotação é fundamental no processo educativo, pois muitas vezes esses estudantes não são compreendidos, ao contrário, são completamente negligenciados pelo contexto educacional, podendo gerar desperdício de potencial. Acreditamos que a participação em programas especiais pode favorecer o declínio de problemas de ajustamento, pois passam a conviver com pessoas que apresentam características semelhantes e o encontro com seus pares propicia autoconhecimento. (LIMA; MOREIRA, 2018. p. 285).

Para Santos e Fleith (2018), cabe ressaltar que a identificação é somente uma das etapas a serem atingidas junto aos alunos superdotados, já que tão importante quanto identificá-los, é dar-lhes oportunidades para estimularem seu potencial e atenderem suas necessidades pessoais.

Vale salientar que a morosidade na identificação deste estudante e o não atendimento as suas necessidades especiais poderão gerar uma série de desajustes ao desenvolvimento desse aluno, colocando-o em situações de risco acadêmico e social. Quanto mais cedo for identificado o estudante, mais chances de ele tornar-se apto a utilizar seus talentos no sentido de atingir satisfação e produtividade em sua vida. 


\section{CONSIDERAÇÕES FINAIS}

Em seu conjunto, é plausível acreditarmos que as informações levantadas na primeira fase da pesquisa apresentam um panorama significativo para a identificação dos indicadores das Altas Habilidades/Superdotação que se mostra indissociável àquela idade e série, ressaltando, dessa forma, o seu caráter exploratório. Sendo assim, tem-se relevante a realização desta pesquisa, pois os estudantes que estão apresentando os indicadores de AH/SD ainda terão uma caminhada escolar e mais oportunidades de aprimorar suas habilidades e aprofundar seus interesses.

Assim, num primeiro momento, entendemos que um dos objetivos propostos foi alcançado, de maneira que apareceram estudantes com indicadores de Altas Habilidades/ Superdotação na triagem realizada, embora haja ainda necessidade de maior informação da temática nas escolas, de formação de equipe pedagógica para uma indicação mais fidedigna, o qual constitui um fator que pode contribuir significativamente para a desmitificação dos mitos em relação às AH/SD.

Notamos também que é necessário enfrentarmos alguns desafios em relação ao contexto e às condições (ambiente, espaço, recurso, condições psicopedagógicas) onde estão sendo aplicados os instrumentos de triagem, de modo que tem gerado reflexões acerca de como se pode superar tal problemática. A equipe, desse modo, tem ponderado e adequado a investigação, seleção, avaliação e o encaminhamento destes estudantes ao CEAM/AHS.

$\mathrm{Na}$ segunda fase desta pesquisa (em andamento), estão sendo realizadas as avaliações destes estudantes selecionados, poderá nos fornecer base empírica para obtermos os dados que julgamos necessários para a interpretação e análise da realidade pesquisada, possibilitando um aprofundamento ainda maior sobre a realidade das escolas públicas estaduais de Campo Grande, tendo, invariavelmente, como horizonte investigativo, esse público-alvo da Educação Especial. 


\section{REFERÊNCIAS}

BRASIL. Ministério da Educação. Secretaria de Educação Especial. Política nacional de educação especial na perspectiva da educação inclusiva. Brasília, DF: MEC/SEESP, 2008.

CHACON, M. C. M; MARTINS, B.A. Alunos precoces no Ensino Fundamental I: quem são essas crianças? Revista Educação Especial. v. 29, n. 54, p. 233-246, 2016. Disponível em:< http://www.ufsm.br/revistaeducacaoespecial $>$. Acesso em: abr.2019.

GARDNER, H. Estruturas da mente: a teoria das inteligências múltiplas. Tradução de Sandra Costa. Porto Alegre: Artes Médicas, 1994.

GODOY, A. S. Refletindo sobre critérios de qualidade da pesquisa qualitativa. GESTÃo. Org - Revista Eletrônica de Gestão Organizacional, v. 3, n. 2, p.80-89, mai./ago. 2005. Disponível:<https://periodicos.ufpe.br/revistas/gestaoorg/article/view/21573/18267> Acesso em: 24 de out.de 2019.

GONÇALVES, F. C.; FLEITH, D.S. Alternativas de identificação de alunos superdotados. In PISKE, F. H. R.; MACHADO, J. M. S. B.; STOLTZ, T.; (eds.). Altas Habilidades/ Superdotação (AH/SD) e Criatividade: Identificação e atendimento. Curitiba: Juruá, 2016, p. 277-288.

LIMA, D. M. P.; MOREIRA, L. C. O professor frente à identificação do estudante com Altas Habilidades/ Superdotação na universidade. In VIRGOLIM, A. Altas Habilidades/ Superdotação: processos criativos, afetivos e desenvolvimento de potenciais. Curitiba: Juruá, 2018, p. 271-286.

MARCONI, M. A. LAKATOS, E. M. Metodologia Científica. 5. ed. São Paulo: Atlas, 2011.

PÉREZ, S. P. B.; FREITAS, S. N. Manual de Identificação de Altas Habilidades/Superdotação. Guarapuava: Apprehendere, 2016.

PÉREZ, S. G. P. B. Encontros e desencontros na identificação dos indicadores de Altas Habilidades/Superdotação. Revista Psicologia Argumento. v. 31, n. 72, p. 57-78, jan./ mar. 2013. Curitiba. Disponível em: <http://dx.doi.org/10.7213/psicol.argum.7582>. Acesso em: 24 de out. de 2019. 
PISKE, F. H. R. Alunos com Altas Habilidades/Superdotação (AH/SD): como identificá-los? In: PISKE, F. H. R.; MACHADO, J. M. S. B.; STOLTZ, T.; (orgs.). Altas Habilidades/Superdotação (AH/SD) e Criatividade: Identificação e atendimento. Curitiba: Juruá, 2016, p. 249-259.

RENZULLI, J. S. The three-ring conception of giftedness: a developmental model for creative productivity. In: RENZULLI, J. S.; REIS S. The triad reader. Mansfield Center (CT): Creative Learning Press, 1986, p. 53 - 92. Disponível em: $<$ https://www.researchgate.net/publication/237668711_The_ThreeRing_Conception_of_Giftedness_A_Developmental_Model_For_Promoting_Creative_Productivity>. Acesso: 26 jun. 2018

RENZULLI, J. S.; REIS, S. M. The School wide enrichment model: a how-to guide for education al excellence. 2 ed.. Mansfield Center, CT: Creative Learning Press, 1997.

RENZULLI, J. S. O que é esta coisa chamada superdotação, e como a desenvolvemos? Uma retrospectiva de vinte e cinco anos. Educação, Porto Alegre: RS, n.1 (52), p. 75-131, jan/abr, 2004.

SANTOS, F. C. G. S; FLEITH D. S. Alternativas de Identificação de alunos superdotados. In: PISKE, F. H. R.; MACHADO, J. M. S. B.; STOLTZ, T. (orgs.). Altas Habilidades/ Superdotação (AH/SD) e Criatividade: Identificação e atendimento. Curitiba: Juruá, 2016, p. 277-288. 


\title{
CAPÍtULO 7
}

\section{DESAFIOS E AVANÇOS DAS}

ESCOLAS E PROFESSORES

FRENTE A EDUCAÇĀO ESPECIAL

\author{
Juliana Campos Francelino ${ }^{1}$
}

1 Bacharel em Direito pelo Centro Universitário Anhanguera de Campo Grande (2014). Especialista em Direito e Processo do Trabalho e Direito Previdenciário pela Estácio de Sá (2015). Especialista em Docência do Ensino Superior pela Universidade Católica Dom Bosco (2018). Mestra em Educação pela Universidade Católica Dom Bosco (2021). Graduanda em Pedagogia pela UNIGRAN Capital (2022). 
Resumo: Os profissionais da educação possuem inúmeros desafios em seu dia-a-dia nas escolas, diversos fatores contribuem para esses desafios, como: falta de reconhecimento, baixos salários, jornadas excessivas de trabalho, ausência de formação continuada, ausência de material didático e de apoio, dentre outras demandas, desafios ainda maiores é garantir diante dessas adversidades que a educação especial ocorra de forma igualitária a todos os educandos. O sistema jurídico existente no Brasil que regula quanto a inclusão da pessoa com deficiência na esfera educacional, deixa evidente a real preocupação dos poderes públicos em relação a inclusão dos alunos com alguma demanda especial. Porém, ainda é notório as dificuldades existentes frente a essa integração. Para responder aos objetivos dessa pesquisa foi realizado um estudo teórico e de análise documental, com destaque na análise de conteúdo de leis, decretos, resoluções. A pesquisa teve enfoque qualitativo por meio de revisão bibliográfica dos principais marcos das políticas públicas voltadas para a inclusão das pessoas com deficiência no sistema de ensino no Brasil. Partindo dessas referências, esta pesquisa teve dentre os seus objetivos apontar os desafios e avanços das escolas e dos profissionais da educação frente as demandas dos alunos com algum tipo de deficiência. Frente a esses desafios, o processo educativo cumpre seu papel quando garante ao aluno os requisitos culturais necessários para uma formação humanizada e transformadora. Assim sendo, a escola deve propiciar a evolução dos conhecimentos científicos, permitindo ao aluno o acesso à cultura e visão da totalidade histórica. Aos profissionais da educação resta a demanda em garantir uma efetiva inserção do aluno com deficiência frente as peculiaridades de cada ser humano. Para que a inclusão educacional ocorra de fato, é necessária uma escola acolhedora que veja a todos com igualdade, e que garanta o acesso de todos os alunos ao conhecimento, a socialização e à convivência.

Palavras-Chave: Formação de Professores. Inclusão. Educação Especial.

\section{INTRODUÇÃo}

Os profissionais da educação possuem inúmeros desafios em seu dia-a-dia nas escolas, diversos fatores contribuem para esses desafios, como: falta de reconhecimento, baixos salários, jornadas excessivas de trabalho, ausência de formação continuada, ausência de material didático e de apoio, dentre outras demandas, desafios ainda maiores é garantir diante dessas adversidades que a educação especial ocorra de forma igualitária a todos os educandos.

A escola tem o dever de acolher o aluno com algum tipo de deficiência, da mesma maneira como garante o acesso dos demais alunos, essa recepção deve ocorrer sem 
exceção, independentemente da cor do indivíduo, sua classe social, seu gênero, e suas condições físicas e psicológicas. Essas e outras garantias estão amparadas na legislação Brasileira.

A Constituição Federal/88, no Capítulo II - Direitos Sociais, garante em seu artigo Art. $6^{\circ} .:$ "o direito a todos sem distinção de qualquer natureza a educação, saúde, lazer, proteção à infância, dentre outras garantias constitucionais". Assim como na CF, a LDB garante através do Art. $4^{\circ}$. o seguinte:

Lei 9.394/96 - Estabelece as diretrizes e bases da educação nacional.

Art. $4^{\circ} \mathrm{O}$ dever do Estado com educação escolar pública será efetivado mediante a garantia de:

III - atendimento educacional especializado gratuito aos educandos com deficiência, transtornos globais do desenvolvimento e altas habilidades ou superdotação, transversal a todos os níveis, etapas e modalidades, preferencialmente na rede regular de ensino;

Ainda no que tange sobre as garantias e direitos da pessoa com deficiência, a Lei 7.853/89 discorre sobre o apoio às pessoas com deficiência, a sua integração social, e garantias na área da educação:

I - na área da educação:

a) a inclusão, no sistema educacional, da Educação Especial como modalidade educativa que abranja a educação precoce, a pré-escolar, as de $1^{\circ}$ e $2^{\circ}$ graus, a supletiva, a habilitação e reabilitação profissionais, com currículos, etapas e exigências de diplomação próprios;

b) a inserção, no referido sistema educacional, das escolas especiais, privadas e públicas;

c) a oferta, obrigatória e gratuita, da Educação Especial em estabelecimento público de ensino;

d) o oferecimento obrigatório de programas de Educação Especial a nível pré-escolar, em unidades hospitalares e congêneres nas quais estejam internados, por prazo igual ou superior a 1 (um) ano, educandos portadores de deficiência;

e) o acesso de alunos portadores de deficiência aos benefícios conferidos aos demais educandos, inclusive material escolar, merenda escolar e bolsas de estudo;

f) a matrícula compulsória em cursos regulares de estabelecimentos públicos e particulares de pessoas portadoras de deficiência capazes de se integrarem no sistema regular de ensino; 
O sistema jurídico existente no Brasil que regula quanto a inclusão da pessoa com deficiência na esfera educacional, deixa evidente a real preocupação dos poderes públicos em relação a inclusão dos alunos com alguma demanda especial. Porém, ainda é notório as dificuldades existentes frente a essa integração, restando-nos um momento de reflexão frente a essa realidade, pois:

A atmosfera de inclusão que se instalou nessas últimas décadas e que exige a todo o momento um tratamento igualitário aos supostamente "diferentes" de diversas ordens seria um refinamento da produção dos diferentes. Novas palavras, novas práticas? Ou antigas práticas (re)atualizadas? Incluir para observar, encaixar, colocar num ponto estratégico de observação dos desvios? Estaríamos, na escola inclusiva, preparados para lidar com ambiguidades, ambivalências, indefinições, "diferenças", sem, contudo, estigmatizar, delimitar espaços, estabelecer fronteiras fixadas de forma concreta ou imaginária?. (SCHILLING e MIYASHIRO, 2008, p. 247).

O estigma perante a pessoa com deficiência é um dos fatores negativos apontados na inclusão desse aluno no cotidiano escolar, a dificuldade no trato e interação do professor-aluno contribuem para o seu isolamento. Castro (2015), apresenta o estigma evidente no tratamento do "sujeito" onde é comumente tratado como "portador de deficiência", essa expressão é questionável, pois, a deficiência não "se porta" ou "se carrega" ela faz parte do indivíduo.

\section{METOLOGIA E OBJETIVOS DA PESQUISA}

Para responder aos objetivos dessa pesquisa foi realizado um estudo teórico e de análise documental, com destaque na análise de conteúdo de leis, decretos, resoluções, dentre eles: Constituição Federal de 1988, seguindo pela Lei de Diretrizes e Bases da Educação Nacional n ${ }^{\circ}$ 9.394/96, a lei 7.853/89 que discorre sobre o apoio às pessoas com deficiência, a sua integração social, e garantias na área da educação, assim como os autores Ferreira, Mantoan, Sassaki, Saviani, dentre outros.

A pesquisa teve enfoque qualitativo por meio de revisão bibliográfica dos principais marcos das políticas públicas voltadas para a inclusão das pessoas com deficiência no sistema de ensino no Brasil. 
As pesquisas de cunho bibliográfico estão inseridas nos ambientes acadêmicos e tem como objetivo aprimorar e atualizar o conhecimento através das investigações científicas já realizadas. Andrade (2010) reconhece que:

A pesquisa bibliográfica é habilidade fundamental nos cursos de graduação, uma vez que constitui o primeiro passo para todas as atividades acadêmicas. Uma pesquisa de laboratório ou de campo implica, necessariamente, a pesquisa bibliográfica preliminar. Seminários, painéis, debates, resumos críticos, monográficas não dispensam a pesquisa bibliográfica. Ela é obrigatória nas pesquisas exploratórias, na delimitação do tema de um trabalho ou pesquisa, no desenvolvimento do assunto, nas citações, na apresentação das conclusões. Portanto, se é verdade que nem todos os alunos realizarão pesquisas de laboratório ou de campo, não é menos verdadeiro que todos, sem exceção, para elaborar os diversos trabalhos solicitados, deverão empreender pesquisas bibliográficas (ANDRADE, 2010, p. 25).

Partindo dessas referências, a intenção dessa pesquisa foi realizar um estudo e dar conhecimento do que está disponível em relação as Políticas Públicas Educacionais de Inclusão da Pessoa com Deficiência no Brasil, com vistas a contribuir para as discussões acerca dessa temática, a fim de apresentar suas características e suas contribuições na inclusão da pessoa com deficiência no âmbito de educação especial.

Sanchez (1998) compreende que:

Faz-se necessária a realização frequente de avaliações a respeito do que tem sido desenvolvido, em termos de pesquisa científica, nas diversas áreas do conhecimento e, mais precisamente, nos programas de pós-graduação stricto sensu, uma vez que estes concretizam espaços privilegiados pelo sistema educacional brasileiro para o desenvolvimento da pesquisa científica. (SÁNCHEZ, 1998, p. 144)

Diante ao exposto, esta pesquisa teve dentre os seus objetivos apontar os desafios e avanços das escolas e dos profissionais da educação frente as demandas dos alunos com algum tipo de deficiência.

\section{DESAFIOS DA ESCOLA}

Segundo levantamento realizado pelo Instituto Brasileiro de Geografia e Estatística - IBGE, em 2019, no Brasil quase 25\% da população possuía algum tipo de deficiência, esse percentual corresponde a aproximadamente 45 milhões de pessoas (IBGE, 2019). 
Para fins de caracterização de deficiência, no Brasil por meio da Lei n ${ }^{\circ}$ 13.146/2015 - Estatuto da Pessoa com Deficiência, considera pessoa com deficiência aquela que:

Art. $2^{\circ}$. Considera-se pessoa com deficiência aquela que tem impedimento de longo prazo de natureza física, mental, intelectual ou sensorial, o qual, em interação com uma ou mais barreiras, por obstruir sua participação plena e efetiva na sociedade em igualdade de condições com as demais pessoas (BRASIL, 2015).

Para atendimento e acolhimento da pessoa com deficiência na escola, é necessária uma estrutura capacitada para atender as demandas que os alunos necessitam, a escola precisa desempenhar seu papel acolhedor e garantir acima de tudo uma educação igualitária e de qualidade para todos.

Ferreira e Guimarães (2003) enfatizam sobre o papel da escola, o seguinte:

"A educação de qualidade para TODOS" é um novo paradigma, de pensamento e de ação, no sentido de ter como "ideal" uma sociedade na qual a diversidade seja mais norma do que exceção. O desafio é estender essa proposta a um número cada vez maior de crianças, escolas e comunidades, com o principal propósito de facilitar e contribuir para a aprendizagem de TODOS. Quando as escolas não excluírem mais ninguém, independentemente de suas condições físicas, psíquicas, econômicas e outras, a diversidade será respeitada e promovida como um valor na sociedade, com resultados visíveis de solidariedade e de cooperação [...]. (FERREIRA; GUIMARÃES, 2003, p. 44).

Frente a esses desafios, o processo educativo cumpre seu papel quando garante ao aluno os requisitos culturais necessários para uma formação humanizada e transformadora. Nessa perspectiva Saviani (2008), reconhece que a educação escolar precisa garantir que o aluno consiga se relacionar com a sociedade, com professores e com os demais alunos de forma crítica, de maneira que possam superar os seus conhecimentos de senso comum e aprimorar os conhecimentos científicos.

Assim sendo, a escola deve propiciar a evolução dos conhecimentos científicos, permitindo ao aluno o acesso à cultura e visão da totalidade histórica. Saviani (2008), reitera que "nesse momento ocorre a efetiva transformação dos instrumentos culturais, convertidos agora em elementos ativos de transformação social” (SAVIANI, 2008, p. 57). 


\section{DESAFIOS DOS PROFESSORES}

$\mathrm{O}$ acolhimento do aluno com deficiência surgiu meramente como um serviço assistencial, com objetivos de garantir apenas o bem-estar da pessoa com deficiência, onde foram levados em consideração principalmente os aspectos psicológicos e médicos de cada indivíduo, posteriormente a essa fase chegou-se então às instituições de ensino com novo objetivo, o de inclusão total desses alunos nas aulas de ensino regular.

[...] atividades complementares envolvendo [...] opcionalmente, a educação de pessoas com necessidades especiais, a educação do campo, a educação indígena, a educação em remanescentes de quilombos, em organizações não governamentais, escolares e não-escolares, públicas e privadas. (SAVIANI, 2008)

Com a mudança dos objetivos entre escola e aluno com deficiência, deixando de ter caráter assistencial para processo formativo e de inclusão, os profissionais da educação precisaram se qualificar a fim de prestar um serviço de qualidade frente aos alunos com demandas especiais que foram inseridos nas classes regulares.

Dentre as demandas mais comuns presentes nas instituições de ensino, encontramos o Braile: que trata de um sistema de escrita tátil utilizada por pessoas com baixa visão ou totalmente cegas. E o interprete de Libras: profissional responsável por utilizar as mãos para se comunicar, a LIBRAS é utilizada por pessoas com dificuldades auditivas ou surdas. É notório a evolução e qualificação dos profissionais da educação quanto a educação especial, porém, ainda é ineficiente a quantidade de profissionais preparados para atuarem nessa área.

Marchesi (2004) aponta alguns dilemas que norteiam os profissionais da educação frente ao aluno com deficiência:

1. O dilema do currículo: um aluno com graves problemas de aprendizagem deve aprender conteúdos iguais ou diferentes aos seus colegas?

2. O dilema da identificação: a identificação dos alunos com necessidades especiais ajuda-os ou os marca negativamente?

3. O dilema pai-profissional: no momento das decisões sobre a escolarização dos alunos, quem tem maior influência?

4. O dilema da integração: uma criança com sérios problemas de aprendizagem aprende mais na classe comum ou na classe especial com mais apoios? (NORWICH, 1993, apud MARCHESI, 2004, p. 37) 
Alguns autores como Bueno (2001) concordam que para garantir o atendimento as necessidades de cada aluno com deficiência, o processo de formação dos profissionais da educação deve ser reformulado e repensado. Para que os professores estejam capazes de atender os alunos a LDB (1996) reconhece que a escola deve garantir profissionais com qualificação especializada para o atendimento adequado, assim como profissionais que não atendem alunos especiais sejam capacitados em suas classes comuns.

Aos profissionais da educação resta a demanda em garantir uma efetiva inserção do aluno com deficiência frente as peculiaridades de cada ser humano. As diferenças podem ser físicas, pessoais, culturais, sociais, linguísticas dentre outras, o professor segundo Bueno (2001), ao reconhecer essas diferenças encontra-se diante de um sistema educacional ineficiente quanto ao atendimento a esses alunos. Esse fato contribui sobremaneira para as discussões acerca da educação especial, tendo em vista uma constante reflexão sobre as práticas pedagógicas indicadas nas instituições de ensino.

\section{CONSIDERAÇÕES FINAIS}

É notório que a inclusão dos alunos com algum tipo de deficiência trata-se de um direito inquestionável, porém, muitos profissionais da educação e instituições de ensino resistem na aceitação e inclusão desse aluno, tendo em vista seu despreparo para que essa inclusão efetivamente ocorra.

Para Sassaki (1997, p. 167) inclusão social trata-se do:

Processo pelo qual a sociedade e o portador de deficiência procuram adaptar-se mutuamente, tendo em vista a equiparação de oportunidade e, conseqüentemente, uma sociedade para todos (...) A inclusão significa que a sociedade deve adaptar-se às necessidades da pessoa com deficiência para que esta possa desenvolver-se em todos os aspectos de sua vida (SASSAKI, 1997, p. 167).

É importante ressaltar que apenas o reconhecimento e diagnóstico prévio da doença, não é suficiente para a recomendação de uma "Receita pronta", cada indivíduo e sua deficiência tem peculiaridades individuais, assim como cada ser humano apresenta suas características, tornando todo o processo de aprendizagem singular e único. 
A educação especial e inclusiva demanda de oferta de profissionais especializados. Fernandes (2008, p. 30) aponta no caso do aluno com surdez, "Alunos surdos, que, por suas necessidades linguísticas diferenciadas, precisam conhecer a língua de sinais e exigem profissionais intérpretes", o acesso do aluno surdo ao interprete de Libras é requisito básico necessário para que ele esteja inserido e acolhido no processo de sua aprendizagem, sem a oferta do interprete é impossível que está inclusão efetivamente ocorra.

É necessário que as instituições de ensino devam estar prontas, para depois receber qualquer aluno que demande de atenção especial. Lev Vygotsky (1896-1934), reconhece que a condição humana é construída ao longo de um processo histórico-cultural, trançado pelas interações sociais entre o indivíduo e o meio.

Frente a essas demandas, a formação dos profissionais da educação nos contextos da educação inclusiva torna-se resultado de sua interação e vivência cotidiana com cada um dos educandos, com deficiência ou não, sendo possível a partir de uma prática pedagógica que reconhece e valoriza as diferenças de todos, tornar o processo de inclusão igualitário e homogêneo.

Para que a inclusão educacional ocorra de fato, é necessária uma escola acolhedora que veja a todos com igualdade, e que garanta o acesso de todos os alunos ao conhecimento, a socialização e à convivência. Mantoan (2003), enfatiza que a escola para cumprir efetivamente seu papel, deve garantir a qualidade no ensino para todos, reconhecendo e respeitando as diferenças, e respondendo a cada cidadão de acordo com as suas necessidades.

\section{REFERÊNCIAS}

ANDRADE, M. M. Introdução à metodologia do trabalho científico: elaboração de trabahos na graduação. São Paulo, SP: Atlas, 2010.

BRASIL. Constituição da República Federativa do Brasil, de 08 de out. de 1988. Brasília, DF, out. 1988. Disponivel em: <https://www2.senado.leg.br/bdsf/bitstream/handle/ id/518231/CF88_Livro_EC91_2016.pdf>. Acesso em: 20 nov. 2021. 
BRASIL. Lei n. 7.853 Dispõe sobre o apoio às pessoas portadoras de deficiência, sua integração social, sobre a Coordenadoria Nacional para Integração da Pessoa Portadora de Deficiência, de 24 de out. de 1989, Brasília, DF, out. 1989. Disponível em: <http://www. planalto.gov.br/ccivil_03/leis/17853.htm>. Acesso em: 20 nov. 2021.

BRASIL. Lei no. 9.394 Estabelece as diretrizes e bases da educação nacional, de 20 dez. de 1996. Brasília, DF, dez. 1996. Disponível em: < http://www.planalto.gov.br/ccivil_03/ leis/19394.htm>. Acesso em: 15 nov. 2021.

BRASIL. Lei no. 13.146, de 6 de julho de 2015. Institui a Lei Brasileira de Inclusão das Pessoas com Deficiência (Estatuto da Pessoa com Deficiência). Diário Oficial [da] República Federativa do Brasil, Poder Executivo, Brasília, DF, 6 jul. 2015a. Disponível em: < http://www.planalto.gov.br/ccivil_03/_ato2015-2018/2015/lei/113146.htm>. Acesso em: 15 out. 2021.

BUENO, José Geraldo Silveira. A inclusão de alunos deficientes nas classes comuns do ensino regular. Temas sobre Desenvolvimento. V.9. n. 54. 2001.

Castro, P. A. (2015). Tornar-se aluno - identidade e pertencimento: perspectivas etnográficas. Campina Grande/PB: UEPB.

FERNANDES, Sueli. Metodologia da Educação Especial. $1^{\text {a }}$ ed. Curitiba. IBPEX, 2008.

FERREIRA, M. E. C.; GUIMARÃES, M. Educação inclusiva. Rio de Janeiro: DP\&A, 2003.

FONSECA, J. J. S. Metodologia da pesquisa cientifica. Fortaleza: UEC, 2002. Apostila. 216-228, mar. 2017.

MANTOAN, Maria Teresa Eglér. Inclusão escolar: o que é? Por quê? Como fazer? São Paulo: Moderna, 2003.

MARCHESI. Álvaro. Da linguagem da deficiência às escolas inclusivas. In. COLL, César; MARCHESI. Álvaro.; PALÁCIOS, Jesús. Desenvolvimento Psicológico e Educação: Transtornos do desenvolvimento e necessidades educativas especiais. V.3; 2.ed. ed. Porto Alegre: Artmed, 2004

SÁNCHEZ GAMBOA, Sílvio Áncizar. Fundamentos para la investigácion educativa: presupuestos epistemológicos que orientan al investigador. Santa Fé de Bogotá: Cooperativa Editorial Magistério, 1998. 138p. (Coleccion mesa redonda; v. n.66). 
SASSAKI, R. K. Inclusão: construindo uma sociedade para todos. Rio de Janeiro, WVA, 1997.

SAVIANI, Demerval. Escola e Democracia. Edição Comemorativa. Edição Comemorativa. Campinas: Autores Associados, 2008.

SCHILING, F., \& MIYASHIRO, S. (2008). Como incluir? O debate sobre o preconceito e o estigma na atualidade. Educação e Pesquisa, 34(2), 243-254. DOI: http://dx.doi. org/10.1590/S1517-97022008000200003 


\title{
CAPÍTULO 8
}

\section{ALTAS HABILIDADESISUPERDOTAÇĀO:}

\section{UM OLHAR PARA IDENTIFICAÇĀO'}

\section{HIGH SKILLSIGIFTEDM: A LOOK AT IDENTIFICATION}

\author{
Marcela Luzio Ferreira Moquiuti
}

1 Este artigo é resultado da análise de um dos eixos temáticos da dissertação de mestrado intitulada: "Avaliação e Identificação de Altas Habilidades/Superdotação no Contexto Escolar" da autora. 2 Mestre em educação; Universidade Estadual de Mato Grosso do Sul - UEMS; Campo Grande ; Mato Grosso do Sul, Brasil; marcelahistur@gmail.com, https://orcid.org/0000-0002-4893-238X 
Resumo: Este artigo trata-se da importância da identificação para estudantes com indicadores de Altas Habilidades/Superdotação - AH/SD e demais sujeitos envolvidos em um processo de Identificação. Constitui uma parte da pesquisa de Mestrado em Educação da Universidade Estadual de Mato Grosso do Sul, intitulada: “Avaliação e Identificação de Altas Habilidades/Superdotação no Contexto Escolar". O estudo foi realizado em duas escolas públicas de Campo Grande MS o qual abordou cinco eixos temáticos sobre o processo de avaliação e identificação de Altas Habilidades/ Superdotação e um dos eixos foi a "A importância da Identificação" que pretendemos apresentar neste artigo após tratar da definição e teoria de AH/SD. Utilizamos como metodologia, a pesquisa bibliográfica pautada na Política de Educação Especial e em pesquisadores que discutem a temática.

Palavras-chave: Altas Habilidades; definição; identificação.

\begin{abstract}
This article deals with the importance of identification for students with indicators of High Skills/Giftedation and other subjects involved in an identification process. It is part of the Master's research in Education of the State University of Mato Grosso do Sul, entitled: "Evaluation and Identification of High Skills/Giftedin the School Context". The study was carried out in two public schools of Campo Grande MS, which addressed five thematic axes on the process of evaluation and identification of High Skills/ Giftedation and one of the axes: "The importance of Identification" we intend to present in this article after addressing the definition on the theme. We used as methodology, the bibliographic research based on the Special Education Policy and researchers who discuss the theme.
\end{abstract}

Keywords: High Skills; definition; identification.

\title{
INTRODUÇÃo
}

O atendimento ao estudante público alvo da educação especial é uma realidade nas escolas públicas de Campo Grande - MS. Profissionais especialistas e auxiliares da área atendem os estudantes com deficiência nas suas especificidades e as Salas de recursos multifuncionais realizam o Atendimento Educacional Especializado - AEE, no entanto ainda que professores e demais profissionais que compõe a equipe escolar não apresentam conhecimento na área da educação especial, existe na unidade escolar o entendimento que os estudantes com deficiência possuem necessidades educacionais especiais às quais devem ser atendidas, mas este entendimento pouco se estende aos estudantes com Altas Habilidades/Superdotação. 
Uma das políticas educacionais que se constituem um marco para se pensar a inclusão dos estudantes com AH/SD é a Política Nacional de Educação Especial na Perspectiva da Educação Inclusiva, instituída em 2008 pelo Decreto n ${ }^{\circ}$ 6571, que trata do Atendimento Educacional Especializado. Nela, assegura-se que:

A educação inclusiva constitui um paradigma educacional fundamentado na concepção de direitos humanos, que conjuga igualdade e diferença como valores indissociáveis, e que avança em relação à ideia de equidade formal ao contextualizar as circunstâncias históricas da produção da exclusão dentro e fora da escola. (BRASIL, 2008, p. 2).

Inserem-se nessa proposta de inclusão os estudantes com deficiência, Transtornos Globais do Desenvolvimento e Altas Habilidades/Superdotação, que constituem o público-alvo da educação especial, mas falta de conhecimento e a existência de muitos mitos em relação às $\mathrm{AH} / \mathrm{SD}$ dificulta a observação dos indicadores de $\mathrm{AH} / \mathrm{SD}$ e consequentemente contribui para invisibilidade destes estudantes.

Há um consenso entre os pesquisadores da área de que é preciso avançar nos estudos e pesquisas sobre a identificação de estudantes com comportamentos de AH/SD, haja vista que essa questão continua permeando muitas discussões sobre a temática.

Dessa forma, a fim de contribuir com esse debate acadêmico, propomos nesse artigo apresentar o resultado de parte da pesquisa de mestrado intitulada: "Avaliação e Identificação de Altas Habilidades/Superdotação no Contexo Escolar” a partir da experiência do Centro Estadual de Atendimento Multidisciplinar para Altas Habilidades/Superdotação (CEAM/AHS) de Campo Grande MS. Nessa proposta abordamos o conceito de altas habilidades/superdotação e as teorias que norteiam o atendimento a esses estudantes e na sequencia apresentamos um dos eixos cinco eixos discutidos na pesquisa: A importância da Identificação.

Para tanto, foi realizada uma pesquisa qualitativa do tipo descritiva, tendo como referencial teórico os estudos de pesquisadores estrangeiros, como Renzulli (1986) e Gardner (1994), e brasileiros que tratam da temática. 


\section{DESENVOLVIMENTO}

O que são altas habilidades/superdotação? Quem são esses indivíduos? Estas são algumas das perguntas que ouvimos de professores das escolas onde acontece o processo de identificação. Além dos professores, a família e o próprio estudante demonstram não ter o entendimento sobre esta temática ou apresentam uma ideia equivocada sobre o conceito e o significado de $\mathrm{AH} / \mathrm{SD}$.

Nos documentos norteadores do Ministério de Educação, dentre os quais a Política Nacional de Educação Especial na Perspectiva da Educação Inclusiva, define-se como alunos com $\mathrm{AH} / \mathrm{SD}$ aqueles que:

[...] demonstram potencial elevado em qualquer uma das seguintes áreas, isoladas ou combinadas: intelectual, acadêmica, liderança, psicomotricidade e artes. Também apresentam elevada criatividade, grande envolvimento na aprendizagem e realização de tarefas em áreas de seu interesse (BRASIL, 2008, p.15).

O processo de identificação de estudantes com indicadores de AH/SD pauta-se na teoria dos Três Anéis do psicólogo Joseph Renzulli, a qual se constitui na base teórica dos atendimentos aos superdotados realizados em todo o Brasil desde a criação dos Núcleos de Atividades de Altas Habilidades/Superdotação - NAAH/S e que propõe o agrupamento de três indicadores: habilidade acima da média, criatividade e envolvimento com a tarefa:

Capacidade Acima da média: Potencial de desempenho representativamente superior em qualquer área determinada do esforço humano e que pode ser caracterizada por dois aspectos: Habilidade Geral: capacidade de processar as informações, integrar experiências que resultem em respostas adequadas a novas situações e a capacidade de envolver-se no pensamento abstrato. Habilidade específicas consistem nas habilidades de adquirir conhecimento e destreza numa ou mais áreas específicas

2. Envolvimento com a tarefa: É o expressivo o interesse que o sujeito apresenta em relação a uma determinada tarefa, problema ou área específica do desempenho, e que se caracteriza especialmente pela motivação persistência e empenho pessoal nesta tarefa.

3. Criatividade: Constitui o terceiro grupo de traços característicos a todas as pessoas com Altas Habilidades e define-se pela capacidade de juntar diferentes informações para encontrar novas soluções. Caracteriza-se pela fluência, flexibilidade, sensibilidade, originalidade, capacidade de elaboração e pensamento divergente. (ALENCAR, 2016, p. 90). 
A avaliação dos estudantes com indicadores de Altas Habilidades/Superdotação deve considerar tais áreas observando os traços de superdotação, partindo das áreas gerais e expandindo para as áreas específicas do desempenho. Nem sempre os traços de superdotação terão a mesma intensidade, mas é importante entender que os três traços devem aparecer nas áreas de desempenho do estudante. Jara (2019) explica que:

O anel da capacidade acima da média representa um conjunto geralmente estável ou constante de características, pois quando essa capacidade está presente em alguma área, ela pode ser constatada ao longo do tempo. Já os grupamentos do comprometimento com a tarefa e da criatividade, nem sempre podem ser constatados ao longo do tempo, porque não podem ser verificados pelos instrumentos tradicionais de detecção das habilidades cognitivas, e não é possível outorgar uma pontuação ao valor da ideia ou à quantidade de esforço e energia que uma pessoa dedica a uma tarefa altamente exigente. (JARA, 2019, p. 44).

Conduzir o trabalho de avaliação e identificação com base em uma teoria é fundamental, pois a teoria é o leme e a bússola que deveriam nos guiar em direção as práticas que evitam aleatoriedade nas metas que buscamos (RENZULLI, 2018). As indagações sobre a temática, tais como: o que a superdotação faz? É um conceito absoluto ou relativo? Identificar é preciso?, possibilitaram a construção da Teoria Geral, construída pelo psicólogo Joseph Renzulli (2018), que é multidimensional, pois aborda vários aspectos, considera as mudanças ao longo dos anos, as experiências, as influências ambientais e o potencial humano.

Entre as áreas abordadas na teoria geral está a liderança para um mundo em mudança - enfatiza a liderança em todas as ações, principalmente frente às mudanças do século XXI. Para Renzulli (2018), as ideias mais criativas, as habilidades analíticas avançadas e os motivos mais nobres podem não resultar em ações positivas, a menos que as habilidades de liderança, como a organização, sequenciação e bom senso, estejam reunidas para enfrentar situações problemas. A habilidade acima da média, o QI, por exemplo, talvez não seja relevante diante de situações que exige o fator liderança.

Virgolim (2007) exemplifica por meio de fatos da biografia de Gandhi em que consiste esse tipo de função executiva - a liderança - relacionada às AH/SD:

O que tornou Gandhi um grande líder foi sua capacidade de descobrir e ressaltar o que há de melhor nas pessoas, estimulando-as a atingir aquilo que elas pensavam ser impossível. É neste sentido que Gandhi também se enquadra na 
definição de liderança criativa que, segundo Sisk (1993), se expressa por quatro aspectos ou atributos:

(a) visão, que permite ver as coisas como são e ainda vê-las da perspectiva do que podem se tornar. Inclui-se aqui também a ideia de ajudar os outros a construir e a compartilhar uma visão comum;

(b) coragem para correr riscos calculados a fim de pôr em prática uma ideia criativa;

(c) absorção ou habilidade de se tornar inteiramente envolvido no ato criativo; e

(d) talento e apreciação do próprio talento para se tornar um líder criativo em algum campo do conhecimento.

Estes fatores interagem com o tempo, história e cultura em que a pessoa vive, dando forma ao tipo de liderança que ela irá desenvolver em seu contexto. (VIRGOLIM, 2007, p. 31).

Por muito tempo, a perspectiva unidimensional permaneceu na prática de profissionais por meio dos testes de QI, que não contemplavam áreas importantes, como a artística e psicomotora, por exemplo, tão pouco a liderança e a capacidade do indivíduo para fazer um bem relevante à sociedade. $\mathrm{O}$ entendimento atual é que essas áreas devem estar entre as avaliadas no processo de identificação, e não somente testes de QI, como esclarece Freitas (2008, p. 275):

Ao referir-se aos alunos com altas habilidades/superdotação, aproxima-se o debate das questões da inteligência, e de como ela vem sendo compreendida neste estudo. Por muito tempo, a inteligência foi vista como um conceito único e unidimensional e passou a ser medida pelos "famosos" Testes de Inteligência, os testes de "QI". Estes testes possuem tabelas numéricas de reconhecimento da inteligência, porém são capazes de medir somente as inteligências lógico-matemática, linguística e espacial. Os testes de "QI" vêm sofrendo críticas, tendo em vista que são aplicados isoladamente, sem levar em consideração a realidade do aluno, nem mesmo levam em consideração as demais capacidades humanas.

A Teoria Geral, construída por Joseph Renzulli, sintetiza a importância de se expandir a avaliação, por meio de um olhar abrangente que permita observar as capacidades humanas. Em um processo de avaliação é importante considerar todas as informações que constam nos instrumentos utilizados, de forma a não apenas identificar o estudante, mas, principalmente, direcioná-lo para um caminho de realizações para si e para a sociedade.

Além da Teoria dos Três Anéis de Joseph Renzulli apresentada acima, a Teoria das Múltiplas Inteligências, de Howard Gardner, também embasa a avaliação e identificação de estudantes com indicadores de altas habilidades/superdotação nas escolas. A teoria de 
Gardner reforça que a avaliação não está direcionada apenas aos estudantes com desempenho excelente nos testes escolares, observados por notas altas em seus boletins, mas também àqueles que se destacam em uma área do conhecimento, e até mesmo em áreas pouco observadas no ambiente escolar.

Segundo Gama (2006), a Teoria das Inteligências Múltiplas permite voltar a atenção a indivíduos com um desempenho maior ou menor em qualquer área de atuação humana. Nessa teoria, são caracterizados oito tipos diferentes de inteligências, quais sejam: 1) Linguística (código, leitura, escrita, história e idiomas); 2) Lógico-matemática (números, lógica, ciências, organização e estratégia); 3) Espacial (paisagem, cores, sonhos, detalhes, pintura e filmes); 4) Corporal-cinestésica (esporte, ar livre, corpo, gestos, sentidos e equilíbrio); 5) Musical (sons, músicas, percepção, ruído e canto); 6) Interpessoal (conselheiro, grupo, líder, comunidade e festas); 7) Intrapessoal (reflexão, meditar, sozinho e independente); e 8) Naturalista (natureza, animais, meio ambiente e jardim).

Smole (1999) explica em que consiste a ideia principal presente na Teoria das Inteligências Múltiplas:

Gardner baseou sua teoria em muitas ideias diferentes, mas a principal delas sustenta que as pessoas manifestam as mais distintas habilidades - para compor uma música, construir um computador ou uma ponte, organizar uma campanha política, produzir um quadro, além de muitas outras-, e que todas essas atividades requerem algum tipo de inteligência, mas não necessariamente o mesmo tipo de inteligência. (SMOLE, 1999, p 8).

Nesse sentido, a teoria de Gardner permite considerar que em um ambiente escolar podem ser encontrados variados tipos inteligências, o que permite concluir que a identificação de estudantes com altas habilidades/superdotação ultrapassa a mera observação de um alto desempenho escolar ou de algum destaque superior - socialmente visível - em alguma área, pois o desempenho escolar pode estar mascarado pelo desestímulo ou o estudante pode não se sentir à vontade para demonstrar em público a área em que se destaca.

Quando não há este entendimento sobre a temática, o estudante com indicadores que até então está invisível aos olhos do professor e da família não chega ao técnico da educação especial para ser avaliado. Deixar de passar por um processo de avaliação que 
lhe possibilitaria aprofundar seus conhecimentos na área de seu interesse pode trazer muitos problemas ao estudante, como desestímulo, descontentamento, depressão e até o rótulo de "estudante problema", fazendo com que suas necessidades educacionais não sejam atendidas.

\subsection{A importância da identificação: o que pensam os sujeitos com Altas Habilidades/ Superdotação.}

Um estudante com ótimo desempenho escolar precisa de atendimento educacional especializado? Um estudante com baixo rendimento pode ter altas habilidades/superdotação? Qual a importância da identificação destes estudantes?

Tendo como referência esses questionamentos, esse eixo tem o objetivo de verificar a importância da identificação não apenas para os estudantes com indicadores de AH/SD, mas também para a escola e a família do estudante, a partir da análise das respostas dos entrevistados.

Para os professores entrevistados, a identificação é importante para todos os envolvidos, como pode ser observado em suas respostas:

O quanto antes identificar habilidades diferenciadas nesses alunos, melhor para o aluno, para o professor e para a escola. (P-A, entrevista, 2019).

Alguns casos vejo que é de suma importância a identificação, por exemplo de estudantes que apresentam problemas, como desestímulo. (P-B, entrevista, 2019).

Tanto o Professor P-A como o Professor P-B manifestam-se favoráveis à identificação de estudantes com indicadores de $\mathrm{AH} / \mathrm{SD}$ e isso representa uma questão positiva quando se trata da educação especial, pois nem sempre encontramos educadores que acham necessário atender aos estudantes que aparentemente apresentam um bom desempenho escolar.

O Professor P-A ressalta a importância da identificação não apenas para o estudante, mas para escola. O Professor P-B expõe a preocupação com o estudante frente ao desestímulo, o que pode interferir no rendimento do estudante mesmo que ele saiba o conteúdo. Em muitos casos, o desestímulo está ligado ao fato de o estudante dominar o conteúdo ou 
ter facilidade para aprender o que está sendo trabalhado na sala comum, o que pode gerar comportamentos inadequados na escola e na família.

Nesse sentido, Piske (2016) esclarece que:

As Altas Habilidades de Superdotados podem até mesmo serem inibidas ou nem serem desenvolvidas na escola. Para explicar este fato basta perceber como muitas aulas são ministradas, não há inovação e, além disso, o próprio sistema educativo repete por muitas vezes o mesmo padrão de ensino fazendo com que as aulas se tornem cansativas e desgastantes, principalmente para alunos com alto potencial. Toda repetição no ensino gera desconforto às crianças superdotadas, que estão sempre buscando novas formas de aprender e descobertas para suas questões em sua (s) área (s) de interesse. (PISKE, 2016, p. 250).

Os estudantes consideram a identificação como um divisor de águas em sua trajetória escolar e demonstraram que a identificação foi muito importante para eles, tanto em sua vida acadêmica como social, pois foi a partir do processo de avaliação e posteriormente de identificação que começaram a desenvolver de forma mais visível as suas habilidades e interesses:

[...] acho que tudo isso que tá acontecendo, a oportunidade de ter apresentado meu trabalho na Fetec e outros projetos incriveis que eu fiz no CEAM, são graças ao CEAM/AHS e talvez eu não teria a oportunidade de fazer na minha escola. (E-A, entrevista, 2019).

Foi importante para melhorar minha confiança pessoal e decisões acerca do meu futuro profissional. (E-B, entrevista, 2019).

Eu sempre tive facilidade para desenhar, mas ser identificado me possibilitou, aprender técnicas e trocar ideias com outras pessoas que desenham também. (E-C, entrevista, 2019).

Após ser identificado, descobri o interesse em outras áreas e vontade de aprofundar em áreas que não sabia que era bom. (E-D, entrevista, 2019).

Como podemos constatar a partir das respostas acima, a identificação de estudantes com indicadores de $\mathrm{AH} / \mathrm{SD}$ promoveu nos participantes uma transformação, uma vez que eles passaram a realizar tarefas e projetos e aprenderam técnicas de seus interesses que não tiveram a oportunidade de realizar na escola.

O estudante identificado em determinada área pode despertar o interesse por outra área completamente diferente e isso é possível porque no processo de avaliação eles têm 
a oportunidade de relatar seus interesses, suas habilidades e as facilidades em desenvolver outras tarefas. Assim, com a orientação e encaminhamento do técnico, os estudantes, descobrem as altas habilidades em outras áreas que jamais imaginavam ter.

Fonseca (2010) em sua pesquisa de mestrado mostra a experiência do processo de identificação em uma rede particular de ensino de Teresina - Piauí, o qual observamos que é semelhante ao que é feito pelo CEAM/AHS. Na experiência de Piauí, a autora retrata a utilização de vários instrumentos, como a indicação por professores, pais e o próprio aluno, e não apenas testes psicométricos. No entanto, apesar de os instrumentos possibilitarem a identificação de áreas artísticas, o processo de avaliação é voltado apenas à área acadêmica, o que indica que muitos estudantes deixam de serem identificados. Já em Campo Grande - MS, o centro realiza um processo de avaliação e identificação abrangendo todas as áreas do conhecimento.

Nesse sentido, o CEAM/AHS constitui-se em um centro de grande importância não apenas para estudantes - de escolas da rede estadual e privada - com indicadores de $\mathrm{AH} /$ SD na área acadêmica, mas em todas as áreas. Além disso, esses estudantes têm a possibilidade de desenvolver projetos tanto em sua área de interesse como em áreas ligadas a habilidades diferentes daquelas com a qual foram originalmente identificados.

A realização de projetos em feiras de tecnologia, por exemplo, é muito significativa para um estudante com comprometimento. A experiência em mostrar suas capacidades por meio de ideias inovadoras para contribuir com a sociedade, dar-lhes confiança e determinação.

Para os responsáveis a identificação representa uma saída para transformar uma situação muitas vezes delicada ou turbulenta, possibilitando que possam entender que seus filhos também são pessoas com necessidades especiais educacionais:

A identificação e a posterior convivência com as outras crianças com altas habilidades foi muito importante pra minha filha, foi extremamente importante, haja vista que no colégio determinado momento antes dela ser diagnosticada certinho, ela estava já tentando tirar notas baixas pra que ela fosse aceita no meio dos coleguinhas do colégio, então a gente presenciou junto com a diretora do colégio, momentos que pra ela ser aceita no meio social, ela tinha que tirar um oito, um sete, porque já estava naquele... né, Nerd, CDF, excluída da turminha que ela gostava e hoje, após algum tempo, é maravilhoso a aceitação dela com 
ela mesma, ao saber que tem muitas crianças e muito mais especiais que ela. Então é muito bacana, ela se aceita e aceita o meio em que ela vive. [...] inclusive é um motivo de muito orgulho pra gente, com tão pouco tempo no CEAM/AHS, ela foi condecorada, ganhou o primeiro lugar nas áreas exatas na FETEC, aqui em campo Grande na Universidade Federal. (R-A, entrevista, 2019).

O filho mais novo foi identificado com altas habilidades na área artística. Após o acompanhamento realizado pelo CEAM-AHS, ele desenvolveu mais as técnicas de desenho e aguçou a criatividade. Fez mais amizades por se identificar com os outros alunos do centro. O filho mais novo, após a identificação, se sentiu mais confiante tanto para o desenho como para o desenvolvimento das atividades acadêmicas. Tanto que após frequentar alguns atendimentos oferecidos pelo CEAM-AHS na área de química, ele pensa em fazer graduação em química. Em casa nós incentivamos essas escolhas. (R-B, entrevista, 2019).

Os responsáveis confirmam que a identificação dos estudantes de certa forma impacta a família inteira, principalmente quando há dificuldades em lidar com as altas habilidades/superdotação. Muitas vezes os pais de um estudante que tem um desempenho acima da média ou uma curiosidade aguçada sobre temas não usuais para sua idade não sabem como ajudar seu filho, não conseguem responder as perguntas que fazem, sentem-se impotentes ao ver seu filho sofrer bullying ou não ser aceito como parte dos grupos juntos a seus pares, conforme mencionado pelo Responsável R-A. Quando percebem que seu filho está feliz e realizado enxergam na identificação, no acompanhamento e encaminhamento de seu filho uma possibilidade de desenvolvimento, aceitação e socialização para a criança ou adolescente com $\mathrm{AH} / \mathrm{SD}$.

Para Gama (2006):

A identificação de alunos superdotados apenas faz sentido quando prece algum tipo de atendimento especializado. A identificação, com o único objetivo de rotular os alunos, não só não presta qualquer serviço, mas, mais do que isso, presta imenso desserviço, uma vez que o rótulo provoca expectativas que a identificação por si só não pode satisfazer. A identificação de crianças e jovens superdotados deve ser feita como componente ou etapa de um sistema de planejamento de programa educacional especial. Por conseguinte, a identificação deve estar diretamente ligada aos objetivos de tal programa (GAMA, 2006, p. 58).

Sob essa ótica, é importante ressaltar que consiste em um mito considerar o estudante com AH/SD como "aluno problema". Para Cunha (2018), a superação desse mito passa pela compreensão, pelos professores, dos fatores relacionados às queixas escolares de estudantes com $\mathrm{AH} / \mathrm{SD}$, visando o planejamento de aulas estimulantes, bem como a 
informação e orientação às famílias, para que conheçam as habilidades de seus filhos e os encaminhem para os serviços de Atendimento Educacional Especializado, e não para serviços da saúde, como ocorre com frequência.

A identificação, portanto, se mostra de grande importância para um estudante com altas habilidades/superdotação e sua família. No entanto, o que vem posteriormente ao processo de avaliação e identificação, ou seja, o Atendimento Educacional Especializado (AEE) é o que garante que esses estudantes tenham garantido o seu direito assegurado na legislação educacional.

\section{CONSIDERAÇõES FINAIS}

As entrevistas com os sujeitos da pesquisa trouxeram questões que demonstraram a complexidade e importância da identificação de estudantes com altas habilidades/superdotação, como a necessidade de se repensar o modelo formativo, atualizar os instrumentos para que tenham uma linguagem mais acessível e estreitar a relação dos técnicos com os professores que participam das avaliações, para que compreendam a temática e assim possam contribuir neste processo.

Espera-se que o estudo possa trazer contribuições para a área da educação especial, especificamente no que se refere ao atendimento educacional especializado aos estudantes com indicadores de altas habilidades/superdotação, para que a comunidade escolar (professores, coordenadores, gestores, pais e responsáveis e os próprios estudantes), bem como a sociedade civil, venha a compreender que as pessoas com AH/SD são reconhecidas na legislação educacional como público-alvo da educação especial e apresentam necessidades educacionais especiais e a identificação portanto, representa para o estudante a garantia do seu direito à inclusão.

\section{REFERÊNCIAS}

ALENCAR, E. M. L. S. Psicologia e educação do superdotado. São Paulo: EPU, 1986. BRASIL. Ministério da Educação. Secretaria de Educação Especial. Política nacional de educação especial na perspectiva da educação inclusiva. Brasília, DF: MEC/SEESP, 2008. 
CUNHA, V. A. B. Estudantes com indicadores de altas habilidades/superdotação e queixas escolares: concepção de suas mães. 2018. 154f. Dissertação (Mestrado em Psicologia do Desenvolvimento e Aprendizagem) - Faculdade de Ciências, Universidade Estadual Paulista, Bauru, 2018.

FONSECA, D. F. Identificação de alunos com Altas Habilidades/Superdotação em escola da rede particular de ensino de Teresina - Piauí. 2010. 110f. Dissertação (Mestrado em Educação) -- Programa de Pós-Graduação em Educação, Universidade Federal do Piauí, Teresina, 2010.

FREITAS, S. N. A identificação e a inclusão de alunos com características de altas habilidades/superdotação: discussões pertinentes. Revista Educação Especial, Santa Maria, n. 32, p. 273-284, 2008.

GAMA, M.C.S. S. A Educação de Superdotados: teoria e prática. São Paulo: EPU, 2006.

GARDNER, H. Estruturas da mente: a Teoria das Inteligências Múltiplas. Tradução Sandra Costa. Porto Alegre: Artes Médicas, 1994.

JARA, G. C. Núcleo de Atividades de Altas Habilidades/Superdotação (NAAH/S): política educacional para o estado de Mato Grosso do Sul. 2019. 118f. Dissertação (Mestrado em Educação) - Programa de Pós-Graduação em Educação, Universidade Católica Dom Bosco, Campo Grande, MS, 2019.

PISKE, F. H. R. Alunos com Altas Habilidades/Superdotação (AH/SD): Como Identificá-los? In: PISKE, F. H. R.; MACHADO, J. M.; BHAIA, S.; STOLTZ, T. (Ed.), Altas Habilidades/Superdotação (AH/SD) e criatividade: identificação e atendimento. Curitiba: Juruá, 2016. p.249-257.

RENZULLI, J. S. The three-ring conception of giftedness: a developmental model for creative productivity. In: RENZULLI, J. S.; REIS, S. M. (Eds.). The triad reader. Mansfield Center: Creative Learning, 1986.

. Reexaminando o papel da educação para superdotados e o desenvolvimento de talentos para o Século XXI: uma abordagem teórica em quatro partes. In: VIRGOLIM, A. (Org.). Altas Habilidades/Superdotação: processos criativos, afetivos e desenvolvimento de potenciais. Curitiba, PR: Juruá, 2018. p. 19-36. 
RENZULLI, J. S; REIS, S. The schoolwide enrichment model: a How-to guide for educational excellence. Mansfield Center: Creative Learning, 1997.

SMOLE, K. C. S. Múltiplas inteligências na prática escolar. Brasília: Ministério da Educação, Secretaria de Educação a Distância, 1999.

VIRGOLIM, A. M. R. Altas habilidade/superdotação: encorajando potenciais. Brasília: Ministério da Educação, Secretaria de Educação Especial, 2007. 


\section{SOBRE A ORGANIZADORA}

\section{Priscilla Basmage Lemos Drulis}

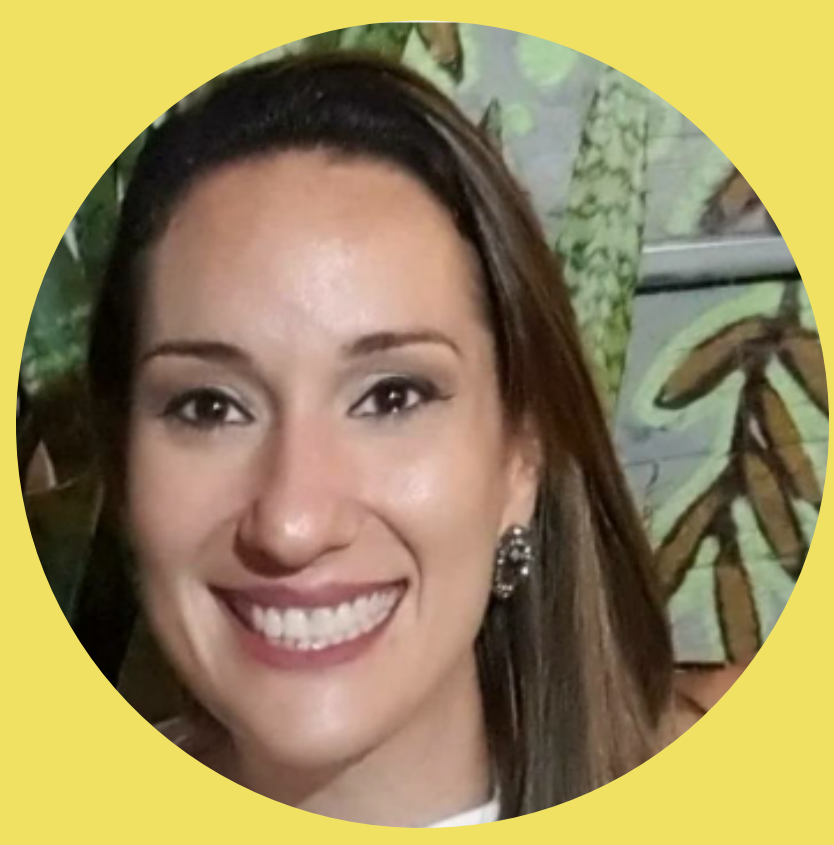

Graduada em Pedagogia pela Universidade Católica Dom Bosco (2004). Pós graduada em Psicopedagogia Clínica e Institucional pela Universidade Católica Dom Bosco (2006). Pós graduada em Educação Especial pela Universidade São Luís (2018). E pós graduada em Gestão Escolar, Supervisão e Coordenação Pedagógica pela Faculdade de Educação, Tecnologia e Administração de Caarapó (2021). Atuo na Educação a 21 anos, dei aula 10 anos para Educação Infantil e Ensino Fundamental I. Lecionei na UNIDERP por 3 anos (02/2014 a 03/2017) para os cursos de Licenciatura em Pedagogia, Letras e Matemática. No ano de 2011 a 2019 foi técnica - Centro Estadual de Atendimento Multidisciplinar para altas habilidades/superdotação, e professora do AEE do CEAM/AHS no ano de 2020. Atualmente atuo como Auxiliar Pedagógica Especializado (APE) na Escola Municipal de tempo Integral Iracema Maria Vicente. Tenho experiência na área de Educação, com ênfase em Educação e Educação Especial. Mestre em Educação pela Universidade Estadual de Mato Grosso do Sul - UEMS. 


\section{www.terried.com \\ @editora_terried (0) \\ leditoraterried ff contato@terried.com M}

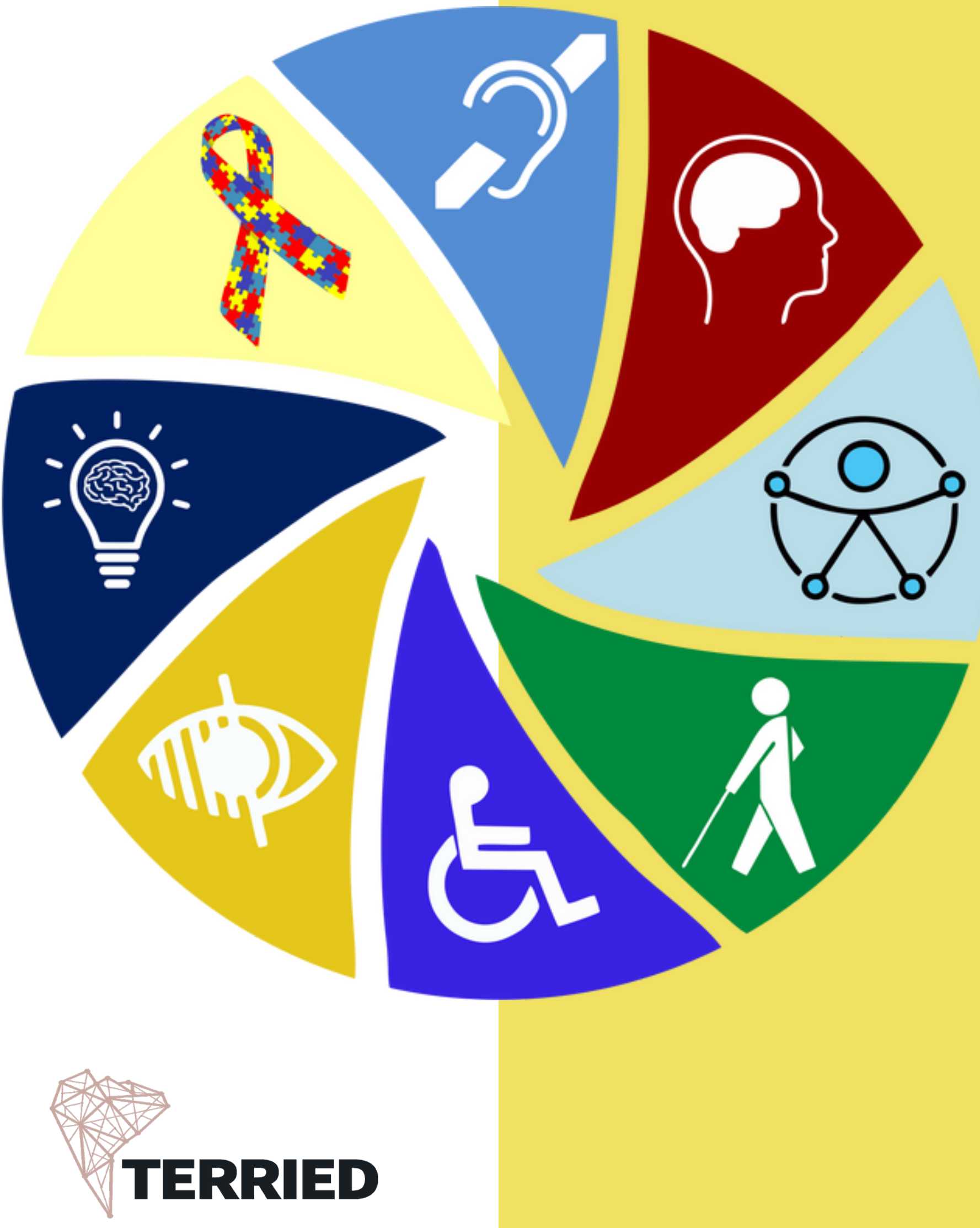

